Ross, P.-S., Ukstins Peate, I., McClintock, M.K., Xu, Y.G., Skilling, I.P., White, J.D.L., et Houghton, B.F. (2005)

Mafic volcaniclastic deposits in flood basalt provinces: a review. Journal of Volcanology and Geothermal Research

145: 281-314

\title{
Mafic volcaniclastic deposits in flood basalt provinces: a review
}

\author{
P.-S. Ross ${ }^{1}$, I. Ukstins Peate ${ }^{2}$, M.K. McClintock ${ }^{1}$, Y.G. Xu ${ }^{3}$, I.P. Skilling ${ }^{4}$ \\ J.D.L. White ${ }^{1}$, B.F. Houghton ${ }^{5}$
}

1: Department of Geology, University of Otago, PO Box 56, Dunedin, New Zealand

2: Department of Geosciences, 121 Trowbridge Hall, University of Iowa, Iowa City IA, USA

3: Guangzhou Institute of Geochemistry, Chinese Academy of Sciences, 510640 Guangzhou, PR China

4: Department of Geology and Planetary Sciences, University of Pittsburgh, SRCC 200 Pittsburgh PA, USA

5: Department of Geology and Geophysics, University of Hawaii, 2525 Correa Rd., Honolulu, HI 96822, USA

* Corresponding author

\begin{abstract}
Flood volcanic provinces are assumed generally to consist exclusively of thick lavas and shallow intrusive rocks (mostly sills), with any pyroclastic rocks limited to silicic compositions. However mafic volcaniclastic deposits (MVDs) exist in many provinces, and the eruptions that formed such deposits are potentially meaningful in terms of potential atmospheric impacts and links with mass extinctions. The province where MVDs are the most voluminous the Siberian Traps - is also the one temporally associated with the greatest Phanerozoic mass extinction. A lot remains to be learned about these deposits and eruptions before a convincing genetic link can be established, but as a first step, this contribution reviews in some detail the current knowledge on MVDs for the provinces in which they are better known, i.e. the North Atlantic Igneous Province (including Greenland, the Faeroe Islands, the British Isles, and tephra layers in the North Sea basin and vicinity), the Ontong Java plateau, the Ferrar, and the Karoo. We also provide a brief overview of what is known about MVDs in other provinces such as the Columbia River Basalts, the Afro-Arabian province, the Deccan Traps, the Siberian Traps, the Emeishan, and an Archean example from Australia.

The thickest accumulations of MVDs occur in flood basalt provinces where they underlie the lava pile (Faeroes: $>1 \mathrm{~km}$, Ferrar province: $\geq 400 \mathrm{~m}$, Siberian Traps: $700 \mathrm{~m}$ ). In the Faeroes case, the great thickness of MVDs can be attributed to accumulation in a local sedimentary basin, but in the Ferrar and Siberian provinces the deposits are widespread ( $>3 \times 10^{5} \mathrm{~km}^{2}$ for the latter). On the Ontong Java plateau over $300 \mathrm{~m}$ of MVDs occur in one drill hole without any overlying lavas. Where the volcaniclastic deposits are sandwiched between lavas, their thickness is much less.

In most of the cases reviewed, primary MVDs are predominantly of phreatomagmatic origin, as indicated by the clast assemblage generally consisting of basaltic clasts of variable vesicularity (dominantly non- to poorly-vesicular) mixed with abundant country rock debris. The accidental lithic components often include loose quartz particles derived from poorly consolidated sandstones in underlying sedimentary basins (East Greenland, Ferrar, Karoo). These underlying sediments or sedimentary rocks were not only a source for debris but also aquifers that supplied water to fuel phreatomagmatic activity. In the Paraná-Etendeka, by contrast, the climate was apparently very dry when the lavas were emplaced (aeolian sand dunes) and no MVDs are reported.

Volcanic vents filled with mafic volcaniclastic material, a few tens of metres to about $5 \mathrm{~km}$ across, are documented in several provinces (Deccan, North Atlantic, Ferrar, Karoo); they are though to have been excavated in relatively soft country rocks (rarely in flood lavas) by phreatomagmatic activity in a manner analogous to diatreme formation.
\end{abstract}

Keywords: flood-basalts; phreatomagmatism; pyroclastic; tuff; volcaniclastic; mafic

\section{Introduction}

Flood basalt volcanism remains a popular explanation for the cause of certain Phanerozoic mass extinctions because of apparent temporal links (e.g., Rampino and Stothers, 1988; Stothers, 1993; Courtillot, 1994; Rampino and Self, 2000; Courtillot and Renne, 2003; White and Saunders, 2005). However, as Wignall (2001) writes, "the [physical] link between large igneous province formation and [mass] extinctions remains enigmatic". One of the mechanisms by which flood basalts can affect the global environment is the cooling effect of huge amounts of sulphate aerosols generated by injection of volcanic $\mathrm{SO}_{2}$ into the stratosphere (e.g., Devine et al., 1984; Sigurdsson, 1990; Campbell et al., 1992; Renne et al., 1995). Degassing of flowing lava is unlikely to have more than regional atmospheric impacts 
(haze), but very vigorous basaltic fire fountaining, invoked for example for the Roza eruption in the Columbia River Basalts, might be capable of injecting $\mathrm{SO}_{2}$ into the stratosphere (Thordarson and Self, 1996).

Attention has turned recently to caldera-forming ignimbrite eruptions for their potential to inject volatiles high in the atmosphere (e.g. Bryan et al., 2002; Jerram, 2002), but generally dacitic and rhyolitic magmas are relatively sulphur-poor, at least compsared to mafic magmas (e.g., Devine et al., 1984; Wallace and Anderson, 2000). Consequently, unless silicic magmas in flood volcanic provinces are unusually rich in sulphur (which there is no suggestion of so far), or are erupted in the course of highly explosive eruptions occurring in quick succession, they seem unlikely candidates for extensive and prolonged environmental impacts if sulphur is indeed the culprit.

One possible means of injecting potentially high amounts of $\mathrm{SO}_{2}$ into the stratosphere would be explosive mafic eruptions. At the present time, there exists a perception that "with the notable exception of the Siberian traps, [mafic] pyroclastics are conspicuously absent from flood basalts" (Cordery et al., 1997). However, recent studies focusing specifically on mafic volcaniclastic deposits (MVDs) within a number of flood basalt provinces, including the Ferrar (Hanson and Elliot, 1996; Elliot, 2000; Elliot and Hanson, 2001), and North Atlantic (Heister et al., 2001; Ukstins Peate et al., 2003a; Larsen et al. 2003), have shown that MVDs are a common and often important component of flood basalt volcanism (Table 1, Fig. 1). In extreme cases such as the Siberian Traps, MVDs are thought to represent about a quarter of the total volume of the province, at least on the Siberian platform (Viswanathan and Chandrasekharam, 1981).

The potential environmental impact of mafic explosive eruptions associated with flood basalts cannot be properly assessed without (1) understanding the role and timing of MVDs in such provinces, their mechanisms of formation and emplacement, lateral distribution and volumetric contribution to flood volcanism; (2) acquiring more data on the pre-eruptive volatile contents of the involved magmas; and (3) modelling the eruption plumes for individual eruptions of known volume and dispersion, and in particular the height of release of volatiles in the atmosphere. This paper contributes towards the first of these goals especially by reviewing the occurrence of explosivelygenerated MVDs in the flood basalt provinces where they are so far best documented, i.e. the North Atlantic Igneous Province, the Ontong Java plateau and the Ferrar and Karoo provinces. We also provide, for the sake of completeness, a brief overview of the little that is known about MVDs in other provinces such as the Columbia River Basalts, the Afro-Arabian province, the Deccan Traps, the Siberian Traps, the Emeishan, and an Archean example from Australia.

\section{North Atlantic Igneous Province}

The early Tertiary North Atlantic Igneous Province comprises a sequence of continental flood basalts and seaward dipping reflectors distributed on Baffin Island (Canada), Greenland, the Faeroe Islands, the Hatton
Bank, the Rockall Plateau, the Vøring Plateau, northern Ireland and north-western Scotland (Saunders et al., 1997; Fig. 2a). Widespread basaltic tephra layers are also found in the North Sea and adjacent regions (details below). Basaltic lava successions in the well-exposed East Greenland portion of the province can reach $>7 \mathrm{~km}$ in stratigraphic thickness (Larsen et al., 1989, Pedersen et al., 1997). MVDs were recognized in the East Greenland flood volcanic stratigraphy by some of the earliest workers in the province (Wager, 1934, 1935, 1947; Nielsen et al., 1981; Brooks and Nielsen, 1982), but the stratigraphic distribution and origin of these deposits has only been addressed in detail in recent studies (Heister et al. 2001; Ukstins Peate et al. 2003a). A relatively detailed description of the most prominent MVDs in the North Atlantic, from East Greenland, the Faeroe Islands, and Northern Europe follows, and a summary of other occurrences is given in Table 2 .

\section{East Greenland}

In East Greenland, flood volcanic rocks have been divided into two main series, informally called the lower volcanics and the plateau lavas (for detailed reviews see Larsen et al., 1989 and Pedersen et al., 1997). The lower volcanics were erupted during the earliest stages of continental break-up (61-57 Ma; Nielsen et al., 1981; Storey et al., 1996; Tegner et al., 1998; Hansen et al., 2002) and represent c. $15 \%$ of the preserved volume (Ukstins Peate et al., 2003a). Primary MVDs (Fig. 3a) compose volumetrically c. 35 to $50 \%$ of the lower volcanics (Figs. 2b \& 2c; for a more detailed description see Ukstins Peate et al., 2003a). The first volcanic rocks of the East Greenland flood basalt province are tuff beds that vary in thickness from $<1$ to $4 \mathrm{~m}$ and form a package that is $c .50 \mathrm{~m}$ in total thickness. Intercalated mudstone lenses displaying desiccation cracks suggest a subaerial deposition environment. The tuffs contain armoured and accretionary lapilli and vitric basaltic clasts, both scoriaceous and dense, some $20 \%$ basaltic lithic fragments, and are also notable for their high content ( $c$. $50 \%$ ) of accidental material (Figs. $4 \mathrm{a} \& 4 \mathrm{~b}$ ). The latter component consists primarily of disaggregated sandsized grains of quartz, calcite and micas, that likely were derived from unconsolidated to partly consolidated early Palaeocene sandstones underlying the volcanic sequence. The abundance of sedimentary material and association with dense glassy basaltic fragments and basaltic lithic clasts suggests phreatomagmatic eruptions.

Overlying the first subaerial tuffs is a thick wedge of hyaloclastites, pillow lavas and pillow breccias which contain foreset-bedded units up to $300 \mathrm{~m}$ thick (Nielsen et al., 1981). The rest of the lower lavas consists of subaerial simple and compound lavas (Soper et al., 1976; Nielsen et al., 1981). Early volcanism was apparently restricted to localized basins and formed a series of shield volcanoes $30-40 \mathrm{~km}$ in diameter that are characterized by heterogeneous sequences of intercalated hyaloclastites, sediments, pyroclastic deposits and lavas. The transition from the lower lavas to the plateau lavas is marked by the $300-1000 \mathrm{~m}$ thick Hængefjeldet Formation, a laterally variable unit composed of subaqueous volcaniclastic and epiclastic deposits to the west (present-day Jacobsen and Miki Fjords) and 
primary volcaniclastic deposits (fall deposits, surge deposits, bomb beds, vent sites) to the east (present-day Ryberg, Jensen and Nansen Fjords; Figs. $2 b$ \& 2c). The primary volcaniclastic deposits in the latter regions appear to have been a source of abundant clastic material that was reworked and redeposited in a distal sedimentary basin in the area of present-day Jacobsen and Miki Fjords. The overlying flood basalts contain a few thin magmatic vitric tuffs $(10 \mathrm{~cm}$ to $1 \mathrm{~m})$ containing Pelé's tears, glass shards and vesicular palagonite (Fig. $4 c)$, but volcaniclastic units decrease up-section and are only found within the lowermost $200 \mathrm{~m}$ of the flood basalts (Ukstins Peate et al., 2003a).

A significantly younger $(\sim 53.8 \mathrm{Ma})$ sequence of MVDs has been identified on an inland nunatak of the East Greenland flood basalt province (Gronau West Nunatak at $30^{\circ} \mathrm{W} / 69^{\circ} \mathrm{N}$, see Fig. 2a; Heister et al., 2001). Some 17 phreatomagmatic basaltic tephras are exposed within a $1 \mathrm{~km}$-thick stratigraphic section representing $c$. $1.6 \mathrm{~m} . \mathrm{y}$. (one tephra layer per two to eight lavas depending on the stratigraphic units; Heister et al., 2001). These tuffs are variably reworked, well lithified, and one layer contains zeolite-filled tree moulds. Tuffs consist of palagonitized sideromelane shards with lesser amounts of basaltic lithic fragments and crystals of plagioclase and clinopyroxene. Heister et al. (2001) state that the majority of shards are 'vesiculated' and blocky, where 'vesiculated' means a few tens of percent vesicles if judged by their Fig. 3b showing a 'typical' glassy basaltic clast. Other shards are described as 'scoriaceous'. Towards the top of the same sequence, a $5-10 \mathrm{~cm}$ thick distinctive layer referred to as the Gronau alkaline tuff is found. This non-basaltic tuff has been correlated to tephra layers found in North Atlantic drill cores and outcrops in Northern Europe based on mineralogy (sanidine, Mg-kataphorite, aegerine), geochemistry and geochronology, and linked to the plausible source of the eruption, the Gardiner complex (about $32.8^{\circ} \mathrm{W} / 68.5^{\circ} \mathrm{N}$, see Fig. 2a), about $185 \mathrm{~km}$ southwest of Gronau West Nunatak (Heister et al., 2001).

\section{Faeroe Islands}

The Faeroe Islands were located only about $100 \mathrm{~km}$ away from the East Greenland margin at the time of initiation of flood volcanic activity, and preserve an erosional remnant of the Palaeogene volcanic succession on a basement of continental crust (Bott et al., 1974). The Faeroe lavas have been divided into three series (the lower, middle and upper series) which total $>5 \mathrm{~km}$ in thickness (Noe-Nygaard and Rasmussen, 1968; Waagstein et al., 1984; Ellis et al., 2002). The lower series has been correlated to the East Greenland prebreak-up 'lower volcanics' succession, whereas the middle and upper series are equivalent to the syn-rifting Milne Land Formation in East Greenland (Larsen et al., 1999).

Some $3 \mathrm{~km}$ of the lavas' thickness is exposed on the islands, but the remaining portion is known only from drilling. The Lopra-1/1A drill hole was deepened in 1996 and it was discovered that below the lowest basaltic lavas, $>1100 \mathrm{~m}$ of MVDs are present, with those in the bottom $665 \mathrm{~m}$ being interbedded with invasive basalt flows or sills (Ellis et al., 2002). Few details are available, but a shallow marine to estuarine depositional environment is inferred based on the fossil population (Ellis et al., 2002).

In the Vestmanna-1 drill hole, the lower lava series contains six lavas with 0.3-4.5 m-thick tuffs intercalated between each flow (the tuffs represent $15 \%$ of the stratigraphic thickness; Waagstein and Hald, 1984). The pre- to syn-rift transition (lower to middle lava series transition) is marked by a local unconformity, with the presence of a 10-20 m-thick coal-bearing sequence, including carbonaceous claystones, siltstones and cross-bedded sandstones in which the clasts consist largely of palagonitized basaltic glass shards and basaltic lithic fragments (Larsen et al., 1999; Ellis et al., 2002). The unconformity identified in the Faeroe Islands may be stratigraphically related to the Haengefjeldet Formation, and record the distal deposition of sparse, reworked MVDs sourced from volcanic activity in the present-day Ryberg Fjord area, and not, as identified by Larsen et al. (1999) a province-wide hiatus in volcanism.

This sequence is followed by a complex assemblage of channelized clastic and volcaniclastic deposits including local accumulations, up to $100 \mathrm{~m}$ in thickness, of basaltic scoria and spatter (Larsen et al., 1999; Ellis et al., 2002). The middle lava series contains only twelve thin beds of tuff (a few mm to $0.9 \mathrm{~m}$ thick), all in the lowermost $200 \mathrm{~m}$. The middle series tuffs have an aggregate thickness of only $2.8 \mathrm{~m}$, corresponding to $0.5 \%$ of the section, and are fine- to coarse-grained, finely bedded units with occasional beds of lapilli (Waagstein and Hald, 1984).

In summary, the earliest known manifestation of North Atlantic Igneous Province volcanism on the Faeroes consist of over a kilometre of MVDs that accumulated in localized shallow marine to estuarine basins; eruptions then produced over $5 \mathrm{~km}$ of subaerial lavas; the $>3 \mathrm{~km}$ thick lower series comprise $15 \%$ mafic volcaniclastic layers but the middle and upper series are much poorer in MVDs.

\section{Northern Europe}

Tephra layers which were erupted in association with flood volcanism and continental break-up in the North Atlantic have been reported from Palaeogene-Eocene sedimentary successions in north-western and central Europe, the North Sea, and the northwest European shelf from the Vøring Plateau (Table 2) to the Goban Spur (Bøggild, 1918; Pedersen et al., 1975; Sigurdsson and Loebner, 1981; Knox, 1984, 1997; Knox and Morton, 1988; Viereck et al., 1988; Morton and Knox, 1990; Emeleus et al., 1996).

In the North Sea over 200 tephra horizons are found, inferred to represent two main phases of activity by Knox and Morton (1983, 1988). Phase 1 volcaniclastic layers (58-57 Ma) consist of (i) reworked ash accumulations and (ii) sporadic graded ash layers. The former have a very limited distribution (mainly NE of Scotland) but form units up to $30 \mathrm{~m}$-thick composed solely of smectite- and palagonite-altered, irregular to rounded vitric particles. Knox and Morton (1988) infer that these deposits were derived from penecontemporaneous reworking of primary volcaniclastic deposits originally deposited near the 
basin margins. The 'graded ash layers' are altered to clay and are up to a few centimetres thick; they are found everywhere in the North Sea. These ashes have variable compositions including mafic, silicic, and peralkaline, and most were probably deposited by turbidity currents based on presence of non-volcanic particles, erosional bed bases, and partial Bouma sequences (Haaland et al., 2000).

Phase 2 graded ashfall deposits (55-52 Ma) are stratigraphically assigned to the Sele Formation (phase 2a), Balder Formation (phases $2 \mathrm{~b} \& 2 \mathrm{c}$ ), and an overlying lower Eocene shale (phase 2d) (Knox and Morton, 1988; Fig. 2d). Phase 2a ash layers are relatively sparse, intercalated in laminated mudstones, and mostly less than $1 \mathrm{~cm}$-thick, although a $27 \mathrm{~cm}$-thick layer is found; the chemical composition is variable (tholeiitic, alkalic, trachytic, trachyandesitic and peralkaline varieties), and the distribution covers the North Sea, surrounding areas, and part of the Atlantic Ocean. Phase $2 \mathrm{~b}$ alone contains over 150 closely-spaced graded ash layers intercalated in laminated mudstones; the ash layers generally are thinner than $3 \mathrm{~cm}$ although one $28 \mathrm{~cm}$ thick layer exists. These ashes covered an area of up to $6 \times 10^{6} \mathrm{~km}^{2}$ (Knox and Morton, 1988). Almost all phase $2 \mathrm{~b}$ ash layers are basaltic in composition based on analyses of correlatives in Denmark (see below). Phreatomagmatic activity has been proposed based on textural studies of volcanic particles (Pedersen and Jørgensen, 1981; Haaland et al., 2000), and each of the phase $2 \mathrm{~b}$ tephra layers is more areally widespread than pyroclastic fall deposits of the 1886 sub-Plinian to Plinian basaltic eruption of Tarawera/Rotomahana in New Zealand (Morton and Knox, 1990). Phase 2c and 2d ash layers resemble those of phase $2 b$ but are thin and less frequent (Knox and Morton, 1988). According to Haaland et al. (2000) most of phase 2 ashes are pyroclastic fall deposits settled through water with no reworking by bottom currents.

In north-western Denmark, approximately 200 ash layers have been identified intercalated with Palaeogene 'mo-clay' sediments (Nielsen and HeilmannClausen, 1988), and comprise a suite with compositions ranging from alkaline basalt, trachybasalt, trachyte, rhyolite, and Ti-rich nephelinite to phonolite (Larsen et al., 2003). Ash layers vary in thickness from $1 \mathrm{~mm}$ to $19 \mathrm{~cm}$, and show normal grading with particle sizes ranging from 100 to $500 \mu \mathrm{m}$ for both mafic and felsic units (Bøggild, 1918). Eruptions increased in frequency with time, and culminated in $>130$ ferrobasalt tephra layers, with an aggregate ash thickness of c. $3.5 \mathrm{~m}$, emplaced over a short duration (these layers are correlated with phase $2 b$ in the North Sea).

This apparent increase in volcanic activity has been attributed to the propagation of proto-Icelandic plume volcanism into the sea-covered opening rift, resulting in large phreatomagmatic eruptions (Larsen et al., 2003; Jerram and Widdowson, 2005). These eruptions, many of which are inferred to have sent ash and sulphur directly into the stratosphere, were synchronous a significant northern hemisphere climate cooling event lasting half a million years (Jolley and Widdowson, 2005). It is inferred that individual eruptive events were not of exceptional volume or violence - a typical Balder eruption perhaps resembling Surtsey 1963-4 in style and Pinatubo 1991 in size - but that the high frequency of the eruptions, combined with the plausibly high sulphur contents of the plumes, allowed a cumulative climatic effect to develop (Jolley and Widdowson, 2005).

\section{3- Ontong Java Plateau}

The Cretaceous Ontong Java Plateau is a submarine flood basalt province with an estimated surface area of $1.86 \times 10^{6} \mathrm{~km}^{2}$ (Coffin and Eldholm, 1994; Fig. 5). Extensions in the Nauru Basin, Manihiki Plateau and Pigafetta/East Mariana basins make this the largest large igneous province currently recognized on Earth (Mahoney et al., 2003). It has been proposed that all basaltic eruptions were effusive and took place below sea level (e.g., Saunders et al., 1996; Coffin and Ingle, 2003). A recent Ocean Drilling Program (ODP) cruise in the eastern lobe of the province (Leg 192, Site 1184) has challenged this view, with the recovery of a $338 \mathrm{~m}$-thick sequence of MVDs, which based on seismic reflection data could be part of a $1500-2000 \mathrm{~m}$ thick unit (Shipboard Scientific Party, 2001). The succession is principally made up of two lithologies: lapilli-tuff (59\% of the total recovered core length) and tuff (34\%). MVDs contain over $95 \%$ juvenile clasts including significant amounts of accretionary and/or armoured lapilli grains (Thordarson, 2004). Most juvenile clasts are non- to sparsely-vesicular sideromelane fragments (or altered equivalents) which are angular and blocky. Highly vesicular glassy fragments with fluidal outlines and sparsely- to poorly-vesicular tachylite grains also occur (Thordarson, 2004).

The presence of wood debris in the MVDs indicates vegetated land nearby, and accretionary lapilli indicate atmospheric eruption plumes. However the nannofossils indicate a submarine depositional environment (Shipboard Scientific Party, 2001). Shipboard investigators concluded that most MVDs are of Eocene age and were re-deposited, perhaps by turbidity currents, on the flanks of a volcano at or below wave base. In contrast, Thordarson (2004) interprets the MVDs as shower-bedded fall layers from 7-11 phreatomagmatic eruptions, perhaps comparable in style to the 1783 Laki eruption in Iceland (Thordarson and Self, 1993, 2003). Several lines of evidence (paleomagnetism; major, trace element and isotope geochemistry; Ar-Ar dating of unaltered juvenile components) suggest that these MVDs are related to the main (Cretaceous) phase of Ontong Java volcanism (Chambers et al., 2004; Fitton and Godard, 2004; Riisager et al., 2004; White et al., 2004), despite the middle Eocene age of nannofossils (Shipboard Scientific Party, 2001).

\section{4- Ferrar}

Rocks of the Ferrar province crop out principally in the Transantarctic Mountains (Fig. 6a), with correlatives in southern Australia and Tasmania (Brauns, 2000; Hergt et al., 2001) and New Zealand (Mortimer et al., 1995). The Ferrar belongs to a group of Jurassic magmatic provinces which also includes the Karoo (Southern Africa, with correlatives in the Weddell Sea sector of Antarctica) and 
the Chon Aike (South America and Antarctic Peninsula). The Chon Aike consists of silicic volcanic rocks (Pankhurst et al., 1998, 2000; Riley et al., 2001) and is only partly contemporaneous with the Karoo and Ferrar, which are dominated by tholeiitic dolerite sills and mafic lavas (Kyle et al., 1981; Cox, 1988; Elliot, 1992). The combined Karoo and Ferrar provinces have an estimated original volume of $\sim 1.5 \times 10^{6} \mathrm{~km}^{3}$ (Eldholm and Coffin, 2000), but the Ferrar itself has relatively modest dimensions (see Table 3).

Four components are present in the Ferrar province: the Dufek Intrusion, the Ferrar Dolerite, the Kirkpatrick Basalt, and associated MVDs. The Dufek Intrusion consists of one or several layered gabbroic bodies in the Pensacola Mountains (Ford and Kistler, 1980; Minor and Musaka, 1997; Ferris et al., 1998), whereas sills and minor dikes intruding the DevonianTriassic Beacon sedimentary sequence make up to the volumetrically dominant Ferrar Dolerite (Ferrar, 1907; Morrison and Reay, 1995; Fleming et al., 1997). Preserved flood lavas (the Kirkpatrick Basalt; Grindley, 1963; Elliot, 1972; Faure et al., 1974; Fleming et al., 1992; Heimann et al., 1994; Elliot et al., 1999) overlying the Beacon Supergroup are subordinate to intrusive rocks and form the uppermost stratigraphic unit in three widely spaced regions spread over $1300 \mathrm{~km}$ (Fig. 6a). The gaps in the Kirkpatrick outcrops are likely due to the present erosional level, not to an originally patchy distribution (it is inferred that the lavas once covered the landscape in the manner of younger flood basalts). The preserved thickness of lavas varies from $380 \mathrm{~m}$ to $780 \mathrm{~m}$, and the basalts are everywhere underlain by MVDs ranging in thickness from 10 to $>400 \mathrm{~m}$ (Fig. 6b; Balance and Watters, 1971; Elliot et al., 1986; Elliot, 2000; see also references in Table 3).

Within individual regions the thickness of MVDs varies widely over tens of kilometres, suggesting that either (i) local eruptive centres produced thick localized volcaniclastic accumulations, possibly for the most part in depressions associated with volcanic activity (White and McClintock, 2001; McClintock and White, submitted) or (ii) there existed significant preMVD topography, perhaps created by extensional tectonics not directly related to volcanic activity (Elliot and Larsen, 1993) or because of normal erosional processes (Balance and Watters, 1971). Both hypotheses likely apply to different sites.

In the Central Transantarctic Mountains, basaltic magmatism was preceded by Early Jurassic(?) deposition of silicic tuffaceous sandstones and tuffs in the uppermost formation of the Beacon Supergroup (Hanson and Elliot, 1996). The fine tuffs are interpreted as distal Plinian fall deposits (Elliot, 2000), and no vents are known. Similar silicic volcaniclastic layers are not well exposed in South Victoria Land, although clasts and megaclasts of very fine silicic tuff are locally present in the Mawson Formation (Bradshaw, 1987; McClintock, 2001).

Jurassic MVDs from all regions (except Carapace Nunatak, just south of Allan Hills) are dominated by poorly sorted, structureless to diffuselylayered tuff-breccias and coarse lapilli-tuffs, with subordinate tuffs and fine lapilli-tuffs (Elliot et al., 1986;
Hanson and Elliot, 1996; Elliot, 2000; Elliot and Hanson, 2001; Fig. 3b). There is a trend in several sections (Otway Massif, Coombs Hills) for deposits to become finer-grained and bedded in the final tens of metres, with the bulk of the underlying sequence (hundreds of metres) showing no signs of bedding. The general coarseness of the MVDs (which include clasts up to $10-20 \mathrm{~m}$ across) generally suggests relative proximity of the deposits to the source of the fragments, especially where bomb sags are documented. Accretionary lapilli are often present in the tuff and fine lapilli-tuffs (Bradshaw, 1987; Hanson and Elliot, 1996; Elliot, 2000; McClintock, 2001). Regardless of deposit grain size or region (except for member $\mathrm{m}_{1}$ at Allan Hills, see below), the main components in the MVDs are blocky, nonvesicular to poorly-vesicular glassy basaltic fragments, together with abundant Beacon sedimentary clasts and sand-sized quartz grains (Elliot et al., 1986; Hanson and Elliot, 1996; Elliot, 2000). This assemblage is illustrated in figures $4 \mathrm{~d}$ to $4 \mathrm{f}$ and is interpreted as the product of the explosive interaction of rising basaltic magma with wet sediments and weakly consolidated sedimentary rocks (the top half of the Beacon Supergroup). More vesicular basaltic fragments also occur in variable proportions in the same samples, indicating a mixture of basaltic clasts having different vesiculation histories (Fig. 4e).

At Coombs Hills and elsewhere, megaclasts of Beacon sedimentary rocks up to hundreds of metres in maximum dimension and rafts of layered volcaniclastic rocks up to tens of metres long "float" in structureless MVDs (Bradshaw, 1987; Elliot, 2000; McClintock, 2001). Equivalent deposits are typically found in the unbedded volcaniclastic facies occupying the lower parts of diatreme-type volcanic conduits, and White and McClintock (2001) interpreted the Mawson Formation at Coombs Hills as a large phreatomagmatic vent complex or "phreatocauldron". New detailed mapping of the facies variations within the vent complex (Ross and White, 2003a, 2003b; Ross, 2005) revealed three principal types of poorly sorted, structureless MVDs: (1) the heterolithologic host for cross-cutting zones of the other types (Fig. 3b); (2) circular vertical pipes of Beacon-rich coarse lapilli-tuff; and (3) irregular-shaped zones of basalt-rich tuff-breccia with in situ peperite domains and pods of coherent glassy basalt (Fig. 3c). Vertical cross-cutting tuff-breccia and lapilli-tuff zones (types $2 \& 3$ ) are interpreted as preserving the trace of individual vents within the larger vent complex.

At nearby Allan Hills, the Mawson Formation is interpreted to fill a pre-existing topographic depression and can be divided into two informal members, $\mathrm{m}_{1}$ and $\mathrm{m}_{2}$. The former member is exposed only in central Allan Hills (although it may occur at depth in the southern part), and is interpreted as a $\leq 180$ m-thick, basalt-depleted debris avalanche deposit (Reubi et al., submitted). Member $\mathrm{m}_{2}$, which overlies $\mathrm{m}_{1}$, is the "normal" (more typical in composition) part of the Mawson and consists mostly of a $\geq 225$ m-thick succession of flat layers (Ross, 2005). The individual layers are up to $15 \mathrm{~m}$ thick, can be traced over several kilometres, and are dominated by coarse lapilli-tuff and tuff-breccia beds, which are compositionally and texturally very similar to the non-bedded facies in the 
Coombs Hills vent complex. These thick layers probably are the deposits of high-concentration pyroclastic density currents given their poor sorting, composition, texture and context (Ross and White, 2004, in prep). Apart from the coarse lapilli-tuff layers, the $\mathrm{m}_{2}$ sequence also contains (1) rare, somewhat thinner finer-grained layers, probably deposited by dilute PDCs; (2) widespread block-rich layers, which probably were deposited by pyroclastic flows or overloaded base surges with simultaneous ballistic fall of large fragments; and (3) beds containing rim-type accretionary lapilli (a.l.) up to $4 \mathrm{~cm}$ in size. The thick layers of southern Allan Hills are underlain by, and locally interstratified with, thinner tuff ring-style layers. These thin layers are likely to represent base surge deposits, and most would have originated from local vents. Non-bedded basalt-rich tuff-breccias and lapilli-tuffs zones, similar to some seen at Coombs Hills, are also present at low elevations, topographically below the layered part of $\mathrm{m}_{2}$ (Ross and White, 2004, in prep).

Geochemical analyses (Ross, 2005) suggest that basaltic plugs, dikes and sills cutting the Mawson Formation, finely crystalline basalt fragments from volcaniclastic rocks in the Mawson, and the flood lavas on Mt Brooke at Coombs Hills, all belong to the Mt Fazio Chemical Type (Fleming et al., 1992), the dominant magma type in the Ferrar province. This indicates that for the Ferrar province, factors such as eruption rate, availability of external water, etc. - rather than any magma behavioural variation resulting from differences in major element chemistry - were involved in controlling the eruption style (effusive versus phreatomagmatic).

In summary, MVDs in the Ferrar predominantly consist of coarse lapilli-tuffs and tuff-breccias up to $400 \mathrm{~m}$ thick which either fill self-generated holes-in-theground (phreatocauldrons or vent complexes) or preexisting topographic depressions. They underlie the Kirkpatrick Basalts throughout the Transantarctic Mountains and represent the phreatomagmatic precursors to flood volcanism.

\section{5- Karoo}

The Karoo province of southern Africa includes a range of mafic to silicic lavas, volcaniclastic rocks and intrusions of mid-Jurassic age resting on and intruding sedimentary rocks of the Karoo Supergroup (Fig. 7a). Remnant outliers over most of southern Africa south of $15^{\circ} \mathrm{S}$ suggest that most of this area was once covered by Karoo lavas and/or underlain by sills (Marsh et al., 1997). Over $1500 \mathrm{~m}$ of tholeiitic lavas in Lesotho and adjacent parts of South Africa, plus the associated sills in the Karoo basin, were emplaced in less than 1 m.y. (Duncan et al., 1997; Hargraves et al., 1997). Subsequent thinning of the continental lithosphere is recorded in a more geochemically diverse volcanic sequence in the Lebombo-Sabi region, near the eventual split between Africa and Antarctica (Duncan et al., 1997; Watkeys, 2002). The "third arm" of the "triple junction" is the Okavango dike swarm, stretching over $1500 \mathrm{~km}$ across Botswana, which recently has been dated about 5 m.y. younger than the Karoo magmas to the south (Jourdan et al., 2004).
In South Africa and southern Lesotho, igneous activity began with eruption of subaerial, and locally subaqueous, basaltic lavas only a few metres to a few tens of metres thick (Lock, 1974; Marsh and Eales, 1984; Mitchell et al., 1996). These early lavas rest on and interfinger with fluvial and aeolian siliciclastic sediments of the upper Karoo Supergroup (Visser, 1984). Effusive volcanism was followed by nonexplosive to explosive interaction between basaltic magma, surface water or groundwater in the Karoo basin to produce voluminous MVDs. The geochemistry of dikes and lavas intercalated with the MVDs and incorporated as lithic blocks within them, indicates that the magma involved in their formation was part of the very first pulse of Karoo igneous activity (J.S. Marsh, pers. commun. to McClintock, 2003). These early magmas are chemically distinct from the later, voluminous Lesotho basalts that make up the bulk of the Karoo lava pile, and have a restricted geographic distribution (Marsh and Eales, 1984; Mitchell et al., 1996).

Known MVDs are scattered irregularly within, and restricted to Lesotho and adjacent parts of South Africa (Fig. 7b). MVDs and associated lavas form the Drakensberg Formation (Fig. 7c), and are exposed locally within an area about $530 \mathrm{~km}$ by $240 \mathrm{~km}$ (Du Toit, 1954). Volcaniclastic occurrences fall into three types and are separated by large areas where Karoo lavas rest directly on the uppermost Karoo Supergroup with few or no intervening volcaniclastic rocks (Fig. 7b). The first type consists of thickly bedded to structureless, mainly coarse-grained MVDs, 100-250 m+ thick, within steepwalled depressions $\left(5-40+\mathrm{km}^{2}\right)$ in pre-existing country rock. The deposits are intercalated with lavas and capped by suberial lava and pillow lava (Fig. 3d). Sheets of thinner-bedded, mainly lapilli and ash-grade deposits, 10-100 m thick, blanket the country rocks surrounding the depressions, and thin away from their margins (Du Toit, 1904, 1905, 1911, 1920; Lock, 1974, 1978; Marsh and Skilling, 1998; McClintock et al., 2002, 2003). The second type consists of basaltic tuff and tuff-breccia within volcanic vents or necks $\left(0.25-2 \mathrm{~km}^{2}\right)$ in the topmost Karoo Supergroup (Du Toit, 1905, 1911; Gevers, 1928), and the third type include lapilli-tuff to breccia-grade basaltic andesite to dacite fragmental units associated with small intrusive-to-extrusive dome complexes (filled triangles on Fig. 7b; Du Toit, 1904; Lock, 1974; Marsh and Eales, 1984; Marsh et al., 1997).

The rest of this discussion deals exclusively with the first type of occurrence because more is known about them and they are more volumetrically significant. These volcaniclastic complexes (e.g., Brosterlea, Modderfontein, Sterkspruit; Fig. 7b) are roughly circular or elliptical in plan. In the Sterkspruit Complex, a great diversity of volcaniclastic rocks, intrusions and lavas within a depression $40+\mathrm{km}^{2}$ is inferred to record the growth of a series of nested vents spaced a few hundred meters apart whose deposits overlap, forming a complex mixture of proximal to distal, intra- to extra vent deposits (McClintock et al., 2003). Craters grew mainly via collapse of their margins rather than by downward quarrying, forming a broad $(5-10 \mathrm{~km}$ ), shallow (few 
hundreds of metres) complex much larger than any single vent or crater.

The MVDs in these complexes are characterized by very poorly developed bedding and poor sorting (Fig. 3e), and comprise mostly lapilli and blocks/bombs with minor ash. They also incorporate metre to tens of metre-sized megablocks of sedimentary country rock and lavas, and are intruded by and incorporate irregular bodies of basalt. Juvenile clasts within the MVDs show wide-ranging but mainly low ( $<30 \%$ vol.) vesicularity and range from blocky to amoeboid in shape. Lithic clasts derived from preexisting country rocks, including abundant loose quartz particles, comprise $>50 \%$, and sometimes $>90 \%$, of these volcaniclastic rocks (Figs. $4 \mathrm{~g} \& 4 \mathrm{~h}$ ). Tack-welded to completely welded deposits composed of 75-99\% degassed subspherical basalt clasts and a few lithic fragments are locally important within some MVD successions. Contacts of the MVDs with adjacent basaltic intrusions and lavas are often irregular, show local development of peperite, and can be traced into coherent intrusions cutting volcaniclastic and/or country rock. Accretionary and armoured lapilli are locally abundant in distal finer-grained fall units blanketing country rock (Fig. 3f) surrounding the complexes.

The margins of the vent complexes are marked by metres to tens of metres-wide screens of monomict country rock breccia that grade laterally into polymict tuff-breccias which incorporate large blocks of country rock. The monomict breccias are often cut by small dikes of basalt. Thin local fluvial and lacustrine facies and pillow lavas cap MVDs within some of the vent complex depressions and indicate some reworking of loose volcaniclastic debris in a wet environment (Fig. 7c). The localized nature of these thin overlying units and the subsequent drowning of the area by subaerial flood basalt flows suggests that the wet environment did not persist.

The shape and wide-ranging vesicularity of many of the juvenile clasts in the Karoo MVDs, the abundance of lithic debris derived from adjacent country rock and the presence of accretionary lapilli are all consistent with fragmentation of magma and country rock by phreatomagmatic explosions. Quarrying of craters and irregular dike-to-volcaniclastic rock transitions within country rock and MVDs point to magma-water interaction within water-saturated country rock and volcaniclastic debris. The near ubiquitous occurrence of minor amounts of peperite clasts in many units suggest an early history of mingling of portions of the melt with unconsolidated or poorly consolidated sediments. However, the localized clastogenic welded deposits rich in degassed basalt with few lithic fragments argue that there were also 'magmatic' explosive eruptions that disrupted fluid magma at shallow levels without significant involvement of external water.

To summarize, MVDs are associated with the first, and compositionally most varied, magmas within the Karoo. Poorly sorted, massive MVDs are widespread at the base of the volcanic sequence in South Africa and Lesotho, and are mostly the products of explosive volcanism. The MVD-forming eruptions overlapped in space and time with a range of non-explosive intrusive and extrusive activity. The explosive volcanism ranged in style from 'magmatic' to phreatomagmatic, with the latter style of activity forming broad, shallow craters that coalesced into large vent complexes. The far-field impacts of these eruptions are poorly constrained, but the presence of tens of metres-thick medial to distal volcaniclastic deposits kilometres from known vent sites suggests that some eruptions may have developed significant buoyant plumes.

\section{6- Lesser-known provinces}

MVDs are known to exist in most other Phanerozoic flood basalt provinces, but much less in known about them so far. Because of the lack of detailed volcanological studies on the MVDs of these provinces, in this section we give only brief summaries, starting with perhaps the most exciting case in terms of the potential environmental impact of MVDs.

\subsection{Siberian Traps}

Although huge estimates of the original volume of the Siberian Traps have been made $\left(1-4 \times 10^{6} \mathrm{~km}^{3}\right.$, e.g., Campbell et al., 1992; Renne et al., 1995; Sharma, 1997), the actual area covered by flood lavas on the Siberian platform is "only" $\sim 3 \times 10^{5} \mathrm{~km}^{2}$ (Fig. 8a). Lavas represent about $37 \%$ of the total volume, with intrusions $(37 \%)$ and volcaniclastic rocks (26\%, mostly MVDs) making up the remainder (Table 4). To our knowledge the age of the MVDs has not been determined by isotopic dating, but stratigraphic position indicates that the thickest volcaniclastic accumulations are older than the lavas (Fig. 8b, columns 2-3), and paleontological information suggests a Late Permian age (Kozur, 1998; Wignall, 2001).

Research on the Siberian Traps has focussed on the Noril'sk region (the northwest corner of the province, Fig. 8a), where the volcanic sequence is about $3.5 \mathrm{~km}$ thick and consists predominantly of low-Ti mafic lavas and intrusive rocks, with only minor (10\%?) MVDs (Zolothukhin and Al'mukhamedov, 1988; Sharma, 1997; Fig. 8b column 1). Some mafic volcaniclastic layers (including 'agglomerates') are up to $100 \mathrm{~m}$ thick, and a $15-25 \mathrm{~m}$ thick layer can be traced over $30,000 \mathrm{~km}^{2}$ (Czamanske et al., 1998). In fact, "the majority of tuff layers can be traced for distances of several tens to hundred of kilometres" (Fedorenko et al., 1996, p. 104). In the lower $1.1 \mathrm{~km}$ of the sequence, MVDs contain an aquatic fauna indicative of deposition in shallow lakes or lagoons, whereas the rest of the sequence was deposited under subaerial conditions (Czamanske et al., 1998).

In the north-eastern arm of the province, volcanic rocks are chemically more diverse than in the Noril'sk region, including over $50 \%$ of high-Ti rocks (versus $<1 \%$ in the Noril'sk region, Fedorenko and Czamanske, 2000). The sequence starts with $320 \mathrm{~m}$ of MVDs (Fig. 8b, column 2), in which basaltic fragments are of the low-Ti type (Fedorenko and Czamanske, 1997). No further description seems available. The thick lavas of the north thin southwards until they disappear completely (Figs. 8a \& 8b columns 3-4).

In the centre of the Tunguska basin, the volcanic sequence is $\sim 1 \mathrm{~km}$ thick including $700 \mathrm{~m}$ of MVDs (Zolothukhin and Al'mukhamedov, 1988; 
Sharma, 1997; Czamanske et al., 1998; Fig. 8b column 3). MVDs in this area are structureless, locally agglomeritic, and contain fragments of porphyritic basalt, gabbro, dolerite, crystals of basic plagioclase, olivine and clinopyroxene, and inclusions of sedimentary rocks; the matrix consists of volcanic glass/ash and altered equivalents (Zolothukhin and Al'mukhamedov, 1988). Some sedimentary fragments consist of dolomites and marls from Devonian strata located 300-1500 m below the base of the "trap" sequence, and rare fragments might originate from depths as great as $10 \mathrm{~km}$ (Campbell et al., 1992).

\subsection{Other provinces}

The occurrence of MVDs in some of the remaining flood basalt provinces where they are known (Columbia River, Afro-Arabia, Deccan Traps, Emeishan, Pilbara craton) are summarized in Table 5 and figures 9 through 13.

\section{7- Summary and conclusions}

As demonstrated by this review, mafic volcaniclastic deposits (MVDs) are known to exist in various proportions in many continental flood basalt provinces (Table 1). MVDs are also associated with some volcanic rifted margins (e.g., North Atlantic, see also Planke et al., 2000), some oceanic plateaus (e.g., Ontong Java), and some Precambrian flood basalts (e.g., Eastern Pilbara craton, discussed in this review; Kostomuksha greenstone belt, see Puchtel et al., 1998).

In certain flood volcanic provinces, MVDs are principally intercalated horizons among lavas whereas in other provinces, MVDs are concentrated in the lower part of the stratigraphy (Fig. 14). In the latter cases, fragmental accumulations can reach hundreds of metres in thickness (Table 6). The areal distribution of MVDs varies from very restricted (e.g., the vent-proximal pyroclastic accumulations on the Columbia River plateau and some MVDs resting on the basement in Yemen) to hundreds of thousands of $\mathrm{km}^{2}$ (Siberian platform, see Figs. 1 and 8a). In some cases, specific tephra layers having distinct geochemical signatures can be correlated over large distances (e.g., the Gronau alkaline tuff from East Greenland has proposed correlatives in the North Sea and Denmark).

Plinian-like distributions are implied for many tephra layers in the North Atlantic, providing a plausible indicator of high subaerial eruption plumes; a direct link with a northern hemisphere climate cooling event in the early Eocene has recently been proposed. In many provinces the deposits comprise not only tuffs but also lapilli-tuffs and tuff-breccias (Table 6), suggesting a general proximity to source vents. In fact some MVDs are interpreted to fill steep-sided vents a few tens of metres to about $5 \mathrm{~km}$ across (Fig. 14). These vents are for the most part thought to have been excavated in the course of phreatomagmatic eruptions in a manner analogous to diatreme formation (e.g., Lorenz, 1986).

MVDs are commonly found intercalated with other volcanic or sedimentary units that indicate the presence of water at the time of eruption, such as hyaloclastites or marine to fluvio-deltaic sediments. Tuff cones/rings or their remnants are documented on the Columbia River plateau (Swanson et al., 1975) and in the Ferrar province (e.g., Ross and White, in prep); these constructs are also typical of phreatomagmatic activity (e.g., Fisher and Schmincke, 1984). Specific observations supporting a dominant role for phreatomagmatic fragmentation in most provinces include (1) the abundance of dense to poorly vesicular blocky sideromelane (or former basaltic glass) clasts; and (2) the abundance of country rock fragments, and in some cases loose quartz particles derived from sandstones underlying the MVDs (Table 6). Accretionary lapilli, found in many provinces (Deccan, East Greenland, Vøring Plateau, Ontong Java plateau, Ferrar, Karoo) indicate subaerial plumes and are commonly (but not exclusively) associated with phreatomagmatic eruptions.

Flood lavas and MVDs overlie siliciclastic sedimentary basins in the East Greenland, Ferrar, Karoo, and Siberian provinces, providing both a potential source for accidental lithic fragments and a permeable subsurface deposit that could act as an aquifer to supply water to fuel phreatomagmatic activity. Quartz grains and xenocrysts (quartz particles engulfed in basaltic clasts) found in MVDs from these provinces indicate that basaltic magma interacted with water-saturated quartzrich sandstones that were generally weakly consolidated or even unconsolidated.

One significant exception to the otherwise ubiquitous presence of MVDs in flood basalt provinces is the Paraná-Etendeka (Brazil and Namibia), which erupted in the Lower Cretaceous during the rifting of Gondwana and formation of the South Atlantic ocean basin (Renne et al., 1996; Stewart et al., 1996; Kirstein et al., 2001). Paraná-Etendeka flood volcanism was erupted onto an extensive inland aeolian sand dune field (Peate, 1997; Jerram et al., 1999, 2000), and the arid environment into which basaltic eruptions took place may explain the apparent complete lack of MVDs. We find the correlation in the Paraná-Etendeka between an apparent desert environment and the lack of associated basaltic pyroclastic volcanism as compelling as the links presented above between established hydrologic reservoirs (aquifers, fluvio-deltaic environments, marine sequences) existing concurrently with volcanism and the occurrence of phreatomagmatic MVDs.

The frequency of phreatomagmatic activity and the minor role of 'magmatic' fragmentation for MVDs in flood basalts is at odds with the silicic volcaniclastic deposits in the same provinces, generally thought to originate by 'magmatic' fragmentation of viscous and vesiculated magmas (Bryan et al., 2002 and references therein). It seems that except in the Paraná-Etendeka, surface water or groundwater was abundant at least locally at some stage in the course of basaltic volcanism. Whether or not rising basaltic magma will interact with a sedimentary aquifer is a function of the geometry of the contact, the state of the magma, the storage characteristics of the water, and eruption dynamics (White and Houghton, 2000). In general in the provinces where phreatomagmatic activity was strong during the early stages but waned with time, one can hypothesize that either (i) the aquifers became exhausted, indicating water recharge rates insufficient to keep pace with arrival of magma, or that eventually the eruption rates 
increased so that the water-magma ratios became too small for energetic interaction; or (ii) volcanism became centralized within conduits sealed by chilled magma (Elliot, 2000; White and McClintock, 2001). Either of these factors, alone or in combination, would result in a shift to quieter lava fountaning and effusion for most of the remaining duration of volcanism.

Current work in the field of large igneous provinces and climate change is beginning to suggest that while silicic pyroclastic eruptions are large-volume and highly explosive, they do not necessarily have a significant, long-term climate impact (e.g., Ukstins Peate et al., 2003b). However, highly explosive mafic volcaniclastic eruptions, with associated high volatile contents $\left(\mathrm{CO}_{2}, \mathrm{Cl}, \mathrm{F}\right.$, sulphur species), may provide the answer to the apparent mis-match observed between climate change events and silicic eruptions in large igneous provinces, as observed in the Yemen-Ethiopian flood basalt province, where silicic volcanism post-dates any observable climate fluctuations, but the initiation of mafic flood volcanism may provide a closer link (Ukstins Peate et al., 2003, in press). In order to refine models of the impact of large igneous provinces on climate change events, we must first provide better constraints on the MVD component, which until now has been neglected.

\section{Acknowledgements}

The work of Ross, McClintock and White on the Ferrar province was supported by Antarctica New Zealand and the University of Otago Research Committee. Ross acknowledges PhD scholarships from the University of Otago and the Fonds de recherche sur la nature et les technologies (Quebec, Canada). Ukstins Peate thanks the University of California (Davis), Royal Holloway University of London, and the Danish Lithosphere Centre for supporting field work for $\mathrm{MSc}$ and $\mathrm{PhD}$ research. The work of McClintock in the Karoo province was supported by National Science Foundation grants EAR0106237 and EAR0106103, and by the University of Hawaii. We thank T. Thordarson for discussions, plus D. Jerram and an anonymous reviewer for constructive reviews of the manuscript.

\section{References}

Ali, J.R., Thompson, G.M., Song, X., Wang, Y., 2002. Emeishan Basalts (SW China) and the end-Guadalupian crisis: magnetobiostratigraphic constraints. J. Geol. Soc. (Lond.) 159, 21-29.

Ali, J.R., Thompson, G.M., Zhou, M.-F., Song, X., 2005. Emeishan large igneous province, SW China. Lithos 79, 475-489.

Anderson, F.W., Dunham, K.C., 1966. The geology of northern Skye. Memoirs of the Geological Survey of Scotland. Geological Survey of Great Britain, Edinburgh, 216 pp.

Arndt, N., Chauvel, C., Czamanske, G., Fedorenko, V., 1998. Two mantle sources, two plumbing systems: tholeiitic and alkaline magmatism of the Maymecha River basin, Siberian flood volcanic province. Contrib. Mineral. Petrol. 133, 297-313.

Baker, J.A., Snee, L., Menzies, M.A., 1996. A brief Oligocene period of flood volcanism at the Afro-Arabian triple junction. Earth. Planet. Sci. Lett. 138, 39-55.

Ballance, P.F., Watters, W.A., 1971. The Mawson Diamictite and the Carapace Sandstone, formations of the Ferrar
Group at Allan Hills and Carapace Nunatak, Victoria Land, Antarctica. N. Z. J. Geol. Geophys. 14, 512-527.

Bell, B.R., Emeleus, C.H., 1988. A review of silicic pyroclastic rocks of the British Tertiary Volcanic Province. In: A.C. Morton and L.M. Parson (Eds.), Early Tertiary Volcanism and the Opening of the NE Atlantic. Geol. Soc. Special Pub. 39, pp. 365-379.

Blake, T.S., 2001. Cyclic continental mafic tuff and flood basalt volcanism in the Late Archaean Nullagine and Mount Jope Supersequences in the Eastern Pilbara, Western Australia. Precamb. Res. 107, 139-177.

Blanford, W.T., 1869. On the geology of the Tapti and Lower Narmada Valleys and some adjoining districts. Reprinted in: K.V. Subbarao (Ed.), Deccan volcanic province, Geol. Soc. India Memoir 43 (1999), pp. 39-68.

Bøggild, O.B., 1918. The volcanic ashes on the 'Mo' clay. Geol. Survey of Denmark Ser. 2, vol. 33

Bondre, N.R., Duraiswami, R.A., Dole, G., 2004. Morphology and emplacement of flows from the Deccan Volcanic Province, India. Bull. Volcanol. 66, 29-45.

Bott, M.H.P., Sunderland, J., Smith, P.J., Casten, U., Saxov, S., 1974. Evidence for continental crust beneath the Faeroe Islands. Nature (Lond.) 248, 202-204.

Bradshaw, M.A., 1987. Additional field interpretation of the Jurassic sequence at Carapace Nunatak and Coombs Hills, south Victoria Land, Antarctica. N. Z. J. Geol. Geophys. 30, 37-49.

Brauns, C.M., Hergt, J.M., Woodhead, J.D., Maas, R., 2000. Os isotopes and the origin of the Tasmanian Dolerites. J. Petrol. 41, 905-918.

Brooks, C.K., Nielsen, T.F.D., 1982. The E. Greenland continental margin: a transition between oceanic and continental magmatism. J. Geol. Soc. (Lond.) 139, 265 275.

Bryan, S.E., Riley, T.R., Jerram, D.A., Stephens, C.J., Leat, P.L., 2002. Silicic volcanism: An undervalued component of large igneous provinces and volcanic rifted margins. In: M.A. Menzies, S.L. Klemperer, C.J. Ebinger and J. Baker (Eds.), Volcanic Rifted Margins. Geol. Soc. Am. Special Paper 362, pp. 97-118.

Campbell, I.H., Czamanske, G.K., Fedorenko, V.A., Hill, R.I., Stepanov, V., 1992. Synchronism of Siberian Traps and the Permian-Triassic Boundary. Science 258, 1760-1763.

Chambers, L.M., Pringle, M.S., Fitton, J.G., 2004. Phreatomagmatic eruptions on the Ontong Java Plateau: an Aptian ${ }^{40} \mathrm{Ar} /{ }^{39} \mathrm{Ar}$ age for the volcaniclastic rocks at ODP Site 1184. In: J.G. Fitton, J.J. Mahoney, P.J. Wallace and A.D. Saunders (Eds.), Origin and evolution of the Ontong Java Plateau. Geol. Soc. Special Pub. 229 pp. $325-331$

Chung, S.L., Jahn, B.M., Wu, G.Y., Lo, C.H., Cong, B.L., 1998. The Emeishan flood basalt in SW China: a mantle plume initiation model and its connection with continental break-up and mass extinction at the Permian-Triassic boundary. In: M.F.J. Flower, S.L. Chung, C.H. Lo. and T.Y. Lee (Eds.), Mantle Dynamics and Plate Interaction in East Asia. Am. Geophys. Union Geodyn. Ser. 27, pp. 4758.

Coffin, M.F., Eldholm, O., 1994. Large igneous provinces: crustal structure, dimensions, and external consequences. Rev. Geophys. 32, 1-36.

Coffin, M.F., Ingle, S.P., 2003. Impact origin of the greater Ontong Java plateau? [abstract], IUGG 2003, Sapporo, Japan, pp. A.211.

Cong B.L., 1988. The formation and evolution of the Panxi paleo-rift system. Scientific Publishing House (in Chinese).

Cordery, M.J., Davies, G.F., Campbell, I.H., 1997. Genesis of flood basalts from eclogite-bearing mantle plumes. J. Geophys. Res., 102, 20,179-20,197. 
Courtillot, V., 1994. Mass extinctions in the last 300 million years: one impact and seven flood basalts. Israel Journal of Earth Sciences 43, 255-266.

Courtillot, V.E., Renne, P.R., 2003. On the ages of flood basalt events. Comptes Rendus Geosciences 335, 113-140.

Cox, K.G., 1988. The Karoo province. In: J.D. Macdougall (Ed.), Continental Flood Basalts. Kluwer Academic Publishers, Dordrecht, pp. 239-271.

Czamanske, G.K., Gurevitch, A.B., Fedorenko, V., Simonov, O., 1998. Demise of the Siberian plume: paleogeographic and paleotectonic reconstruction from the prevolcanic and volcanic record, north-central Siberia. Int. Geol. Rev. 40, 95-115.

Das, K.N., Dixit, V.K., 1972. Geohydrological conditions of the Deccan Traps flows around Saugor (M.P.) India. Bull. Volcanol. 35, 651-659.

Deshmukh, S.S., 1984. Geological and petrographic studies of the Deccan basalt flows and intercalated volcaniclastic beds encountered in drill holes in Bombay city and harbour areas. Geol. Surv. India Rec. 113, 33-51.

Devey, C.W., Lightfoot, P.C., 1986. Volcanological and tectonic control of stratigraphy and structure in the western Deccan traps. Bull. Volcanol. 48, 195-207.

Devine, J.D., Sigurdsson, H., Davis, A.N., Self, S., 1984. Estimates of sulfur and chlorine yield to the atmosphere from volcanic eruptions and potential climatic effects. J. Geophys. Res. 89, 6309-6325.

Drever, H.I., Dunham, K.C., 1969. Northern Syke. In: J.G. Capewell (Ed.), The Tertiary Igneous Geology of the Isle of Syke. Geologists' Association Guides 13, pp. 20-24.

Du Toit, A.L., 1904. Geological Survey of the divisions of Aliwal North, Herschel, Barkley East and part of Wodehouse. Ninth Annual Report of the Cape Geological Commission 71-181.

Du Toit, A.L., 1905. Geological survey of Glen Gray and parts of Queenstown and Wodehouse. Tenth Annual Report of the Cape Geological Commission 97-140.

Du Toit, A.L., 1911. Geological survey of part of the Stormbergen. Sixteenth Annual Report of the Cape Geological Commission 113-136.

Du Toit, A.L., 1920. The Karoo dolerites of South Africa. Trans. Geol. Soc. S. Afr. 23, 1-42.

Du Toit, A.L., 1954. The Geology of South Africa. Oliver and Boyd, Edinburgh, 611 pp.

Duncan, R.A., Hooper, P.R., Rehacek, J., Marsh, J.S., Duncan, A.R., 1997. The timing and duration of the Karoo igneous event, southern Gondwana. J. Geophys. Res. 102, 18,12718,138 .

Duraiswami, R.A., Dole, G., Bondre, N., 2003. Slabby pahoehoe from the western Deccan Volcanic Province: evidence for incipient pahoehoe-aa transitions. J. Volcanol. Geotherm. Res. 121, 195-217.

Eldholm, O., Grue, K., 1994. North Atlantic volcanic margins dimensions and production rates. J. Geophys. Res. 99, 2955-2968.

Eldholm, O., Coffin, M.F., 2000. Large igneous provinces and plate tectonics. In: M.A. Richards, R.G. Gordon and R.D. van der Hilst (Eds.), The History and Dynamics of Global Plate Motions. Am. Geophys. Union, Geophysical Monograph 121, pp. 309-326.

Elliot, D.H., 1972. Major oxide chemistry of the Kirkpatrick Basalt, Central Transantarctic Mountains. In: R.J. Adie (Ed.), Antarctic Geology and Geophysics. Universitetsforlagets, Oslo, pp. 413-418.

Elliot, D.H., 1992. Jurassic magmatism and tectonism associated with Gondwanaland break-up: an Antarctic perspective. In: B.C. Storey, T. Alabaster and R.J. Pankhurst (Eds.), Magmatism and the Causes of Continental Break-up. Geol. Soc. Special Pub. 68, pp. 165-184.
Elliot, D.H., 2000. Stratigraphy of Jurassic pyroclastic rocks in the Transantarctic Mountains. J. Afric. Earth Sci. 31, 7789.

Elliot, D.H., Larsen, D., 1993. Mesozoic volcanism in the central Transantarctic Mountains, Antarctica: Depositional environment and tectonic setting. In: R.H. Findlay, R. Unrug, M.R. Banks and J.J. Veerers (Eds.), Assembly, evolution and dispersal; proceedings of the Gondwana Eight symposium. Balkema, Rotterdam, pp. 397-410.

Elliot, D.H., Hanson, R.E., 2001. Origin of widespread, exceptionally thick basaltic phreatomagmatic tuff breccia in the Middle Jurassic Prebble and Mawson Formations, Antarctica. J. Volcanol. Geotherm. Res. 111, 183-201.

Elliot, D.H., Haban, M.A., Siders, M.A., 1986. The Exposure Hill Formation, Mesa Range. In: E. Stump (Ed.), Geological Investigations in Northern Victoria Land. Antarctic Research Series 46, pp. 267-278.

Elliot, D.H., Fleming, T.H., Conaway, C., Braddock, P., 1997. Geologic studies in the Prince Albert Mountains. Antarctic J. U.S. 32(5), 14-15.

Elliot, D.H., Fleming, T.H., Kyle, P.R., Foland, K.A., 1999. Long-distance transport of magmas in the Jurassic Ferrar Large Igneous Province, Antarctica. Earth Planet. Sci. Lett. 167, 89-104.

Ellis, D., Bell, B.R., Jolley, D.W., O'Callaghan, M., 2002. The stratigraphy, environment of eruption and age of the Faroes Lava Group, NE Atlantic Ocean. In: D.W. Jolley and B.R. Bell (Eds.), The North Atlantic Igneous Province: Stratigraphy, Tectonic, Volcanic and Magmatic Processes. Geol. Soc. Special Pub. 197, pp. 253-269.

Emeleus, C.H., Allwright, E.A., Kerr, A.C., Williamson, I.T., 1996. Red tuffs in the Palaeocene lava successions of the Inner Hebrides. Scottish J. Geol. 32, 83-89.

Faure, G., Bowman, J.R., Elliot, D.H., Jones, L.M., 1974. Strontium isotope composition and petrogenesis of the Kirkpatrick Basalt, Queen Alexandra Range, Antarctica. Contrib. Mineral. Petrol. 48, 153-169.

Fedorenko, V., Czamanske, G., 1997. Results of new field and geochemical studies of the volcanic and intrusive rocks of the Maymecha-Kotuy area, Siberian flood-basalt province, Russia. Int. Geol. Rev. 39, 479-531.

Fedorenko, V., Czamanske, G., 2000. Results of new field and geochemical studies of the volcanic and intrusive rocks of the Maymecha-Kotuy area, Siberian flood-basalt province, Russia. In: W.G. Ernst and R.G. Coleman (Eds.), Tectonic studies of Asia and the Pacific Rim. International Book Series 3, pp. 54-106.

Fedorenko, V., Lightfoot, P.C., Naldrett, A.J., Czamanske, G.K., Hawkesworth, C.J., Wooden, J.L., Ebel, D.S., 1996. Petrogenesis of the flood-basalt sequence at Noril'sk, north central Siberia. Int. Geol. Rev. 38, 99-135.

Ferrar, H.T., 1907. Report on the field geology of the region explored during the 'Discovery' Antarctic Expedition, National Antarctic Expedition 1901-04, Natural History 1, pp. 1-100.

Ferris, J., Johnson, A., Storey, B., 1998. Form and extent of the Dufek intrusion, Antarctica, from newly compiled aeromagnetic data. Earth Planet. Sci. Lett. 154, 185-202.

Fisher, R.V., Schmincke, H.-U., 1984. Pyroclastic Rocks. Springer-Verlag, Berlin, 472 pp.

Fitch, F.J., Heard, G.L., Miller, J.A., 1988. Basaltic magmatism of late Cretaceous and Palaeogene age recorded in wells NNE of the Shetlands. In: A.C. Morton and L.M. Parson (Eds.), Early Tertiary Volcanism and the Opening of the NE Atlantic. Geol. Soc. Special Pub. 39, pp. 253-262.

Fitton, J.G., Godard, M., 2004. Origin and evolution of magmas on the Ontong Java Plateau. In: J.G. Fitton, J.J. Mahoney, P.J. Wallace and A.D. Saunders (Eds.), Origin and 
evolution of the Ontong Java Plateau. Geol. Soc. Special Pub. 229, pp. 151-178.

Fleming, T.H., Elliot, D.H., Jones, L.M., Bowman, J.R., Siders, M.A., 1992. Chemical and isotopic variations in an ironrich flow from the Kirkpatrick Basalt, north Victoria Land, Antarctica: implications for low-temperature alteration. Contrib. Mineral. Petrol. 111, 440-457.

Fleming, T.H., Heimann, A., Foland, K.A., Elliot, D.H., 1997. ${ }^{40} \mathrm{Ar} /{ }^{39} \mathrm{Ar}$ geochronology of Ferrar Dolerite sills from the Transantarctic Mountains, Antarctica: Implications for the age and origin of the Ferrar magmatic province. Geol. Soc. Am. Bull. 109, 533-546.

Ford, A.B., Kistler, R.W., 1980. K-Ar age, composition, and origin of Mesozoic mafic rocks related to the Ferrar Group, Pensacola Mountains, Antarctica. N. Z. J. Geol. Geophys. 23, 371-390.

Fuller, R.E., 1928. The Asotin Craters of the Columbia River Basalt. J. Geol. 36, 56-74.

Gevers, T.W., 1928. The volcanic vents of the western Stormberg. Trans. Geol. Soc. S. Afr. 43-62.

Grapes, R.H., Reid, D.L., McPherson, J.G., 1974. Shallow dolerite intrusion and phreatic eruption in the Allan Hills region, Antarctica. N. Z. J. Geol. Geophys. 17, 563-577.

Grindley, G.W., 1963. The geology of the Queen Alexandra Range, Beardmore Glacier, Ross Dependency, Antarctica; with notes on the correlation of Gondwana sequences. N. Z. J. Geol. Geophys. 6, 307-347.

Haaland, H.J., Furnes, H., Martinsen, O.J., 2000. Paleogene tuffaceous intervals, Grane Field (Block 25/11), Norwegian North Sea: their depositional, petrographical, geochemical character and regional implications. Mar. Petroleum Geol. 17, 101-118.

Hansen, H., Pedersen, A.K., Duncan, R.A., Bird, D.K., Brooks, C.K., Fawcett, J.J., Gittins, J., Gorton, M., O'Day, P., 2002. Volcanic stratigraphy of the sourthern Prinsen af Wales Bjerge region, East Greenland. In: D.W. Jolley and B.R. Bell (Eds.), The North Atlantic Igneous Province: Stratigraphy, Tectonic, Volcanic and Magmatic Processes. Geol. Soc. Special Pub. 197, pp. 183-218.

Hanson, R.E., Elliot, D.H., 1996. Rift-related Jurassic phreatomagmatism in the central Transantarctic Mountains: precursory stage to flood-basalt effusion. Bull. Volcanol. 58, 327-347.

Hargraves, R.B., Rehacek, J., Hooper, P.R., 1997. Palaeomagnetism of the Karoo igneous rocks in southern Africa. S. Afr. J. Geol. 100, 195-212.

He, B., Xu, Y.-G., Chung, S.-L., Xiao, L., Wang, Y., 2003. Sedimentary evidence for a rapid, kilometer-scale crustal doming prior to the eruption of the Emeishan flood basalts. Earth Planet. Sci. Lett. 213, 391-405.

Heimann, A., Fleming, T.H., Elliot, D.H., Foland, K.A., 1994. A short interval of Jurassic continental flood basalt volcanism in Antarctica as demonstrated by ${ }^{40} \mathrm{Ar} /{ }^{39} \mathrm{Ar}$ geochronology. Earth Planet. Sci. Lett. 121, 19-41.

Heister, L.E., O'Day, P.A., Brooks, C.K., Neuhoff, P.S., Bird, D.K., 2001. Pyroclastic deposits within the East Greenland Tertiary flood basalts. J. Geol. Soc. (Lond.) 158, 269-284.

Hergt, J.M., Brauns, C.M., 2001. On the origin of Tasmanian Dolerites. Austr. J. Earth Sci. 48, 543-549.

Hofmann, C., Feraud, G., Courtillot, V., 2000. ${ }^{40} \mathrm{Ar} /{ }^{39} \mathrm{Ar}$ dating of mineral separates and whole rocks from the Western Ghats lava pile; further constraints on duration and age of the Deccan Traps. Earth Planet. Sci. Lett. 180, 13-27.

Hooper, P.R., 1997. The Columbia River flood basalt province: current status. In: J.J. Mahoney and M.F. Coffin (Eds.), Large Igneous Provinces: Continental, Oceanic, and Planetary Flood Volcanism. Am. Geophys. Union, Geophysical Monograph 100, pp. 1-27.
Huang, K.N., 1986. The petrological and geochemical characteristics of the Emeishan basalts from SW China and the tectonic setting of their formation. $\mathrm{PhD}$ thesis, Institute of Geology, Academy Sinica, China (in Chinese).

Huang, K., Opdyke, N.D., 1998. Magnetostratigraphic investigations on an Emeishan basalt section in western Guizhou province, China. Earth Planet. Sci. Lett. 163, 114.

Isaac, M.J., Chinn, T.J., Edbrooke, S.W., Forsyth, P.J., 1996. Geology of the Olympus Range area, southern Victoria Land, Antarctica. Geological Map 20, Scale 1:50,000, folded in the accompanying report, Institute of Geological and Nuclear Sciences, Lower Hutt, New Zealand.

Jassim, S.Z., Gass, I.G., 1970. The Loch na Creitheach volcanic vent, Isle of Skye. Scott. J. Geol. 6, 285-294.

Jerram, D.A., 2002. Volcanology and facies architecture of flood basalts. In: M.A. Menzies, S.L. Klemperer, C.J. Ebinger and J. Baker (Eds.), Volcanic Rifted Margins. Geol. Soc. Am. Special Paper 362, pp. 121-135.

Jerram, D.A., Widdowson, M., 2005. The anatomy of Continental Flood Basalt Provinces: geological constraints on the processes and products of flood volcanism. Lithos 79, 385-405.

Jerram, D., Mountney, N., Holzforster, F., Stollhofen, H., 1999. Internal stratigraphic relationships in the Etendeka Group in the Huab Basin, NW Namibia: understanding the onset of flood volcanism. Journal of Geodynamics 28, 393-418.

Jerram, D.A., Mountney, N.P., Howell, J.A., Long, D., Stollhofen, H., 2000. Death of a sand sea: an active aeolian erg systematically buried by the Etendeka flood basalts of NW Namibia. J. Geol. Soc. (Lond.) 157, 513516.

Jolley, D.W., Widdowson, M., 2005. Did Paleogene North Atlantic rift-related eruptions drive early Eocene climate cooling? Lithos 79, 355-366.

Jourdan, F., Féraud, G., Bertrand, H., Kampunzu, A.B., Tshoso, G., Le Gall, B., Tiercelin, J.J., Capiez, P.., 2004. The Karoo triple junction questioned: evidence from Jurassic and Proterozoic ${ }^{40} \mathrm{Ar} /{ }^{39} \mathrm{Ar}$ ages and geochemistry of the giant Okavango dyke swarm (Botswana). Earth Planet. Sci. Lett. 222, 989-1006.

Khan, W., McCormick, G.R., Reagan, M.K., 1999. Parh Group basalts of the northeastern Balachistan, Pakistan: Precursors to the Deccan Traps. In: A. Macfarlane, R.B. Sorkhabi and J. Quade (Eds.), Himalaya and Tibet: Mountain Roots to Mountain Tops. Geol. Soc. Am. Special Paper 328, pp. 59-74.

Kirstein, L.A., Kelley, S., Hawkesworth, C., Turner, S., Mantovani, M., Wijbrans, J., 2001. Protracted felsic magmatic activity associated with the opening of the South Atlantic. J. Geol. Soc. (Lond.) 158, 583-592.

Knox, R.W. O., 1984. Nanoplankton zonation and the paleocene/Eocene boundary beds of NW Europe: an indirect correlation by means of volcanic ash layers. J. Geol. Soc. (Lond.) 141, 993-999.

Knox, R.W.O'B., 1997. The late Paleocene to early Eocene ash layers of the Danish mo-clay (Fur Formation): stratigraphic and tectonic significance. In: E. Thomsen and S.A.S. Pedersen (Eds.), Geology and paleontology of the mo-clay. Aarhus Geoscience 6, 7-11.

Knox, R.W.O., Morton, A.C., 1983. Stratigraphic distribution of Early Palaeogene pyroclastic deposits in the North Sea Basin. Proceedings of the Yorkshire Geological Society 44, 355-363.

Knox, R.W.O., Morton, A.C., 1988. The record of early Tertiary N Atlantic volcanism in sediments of the North Sea Basin. In: A.C. Morton and L.M. Parson (Eds.), Early Tertiary Volcanism and the Opening of the NE Atlantic. Geol. Soc. Special Pub. 39, pp. 407-419. 
Korsch, R.J., 1984. The structure of Shapeless Mountain, Antarctica, and its relation to Jurassic igneous activity. N. Z. J. Geol. Geophys. 27, 487-504.

Kozur, H.W., 1998. Some aspects of the Permian-Triassic boundary (PTB) and of the possible causes for the biotic crisis around this boundary. Palaeogeogr. Palaeoclim. Palaeoecol. 143, 227-272.

Kruck, W., 1983. Geological map of the Yemen Arab Republic, Sheet Sana'a. 1:250,000. Hannover (Fed. Inst. Geosc. and Nat. Res.).

Kyle, P.R., Elliot, D.H., Sutter, J.F., 1981. Jurassic Ferrar Supergroup tholeiites from the Transantarctic Mountains, Antarctica, and their relationship to the initial fragmentation of Gondwana. In: M.M. Crosswell and P. Vella (Eds.), Gondwana Five; selected papers and abstracts of papers presented at the Fifth International Gondwana Symposium, pp. 282-287.

Larsen, L.M., Watt, W.S., Watt, M., 1989. Geology and petrology of the Lower Tertiary plateau basalts of the Scoresby Sund region, East Greenland. Grønlands Geologiske Unders $\varnothing$ gelse (Geological Survey of Greenland) Bulletin 157, Copenhagen, 164 pp.

Larsen, L.M., Pedersen, A.K., Pedersen, G.K., Piasecki, S., 1992. Timing and duration of Early Tertiary volcanism in the North Atlantic: new evidence from West Greenland. In: Storey, B.C., Alabaster, T., Pankhurst, R.J. (eds.), Magmatism and the causes of continental break-up, Geol. Soc. Special Pub. 68, 321-333.

Larsen, L.M., Waagstein, R., Pedersen, A.K., Storey, M.S., 1999. Trans-Atlantic correlation of the paleogene volcanic successions in the Faeroe Islands and East Greenland. J. Geol. Soc. (Lond.) 157, 1081-1095.

Larsen, L.M., Fitton, J.G., Pedersen, A.K., 2003. Paleogene volcanic ash layers in the Danish Basin: compositions and source areas in the North Atlantic Igneous Province. Lithos 71, 47-80.

Lin, J.Y., 1985. Spatial and temporal distribution of Emeishan basaltic rocks in three southwestern province (Sichuan, Yunnan and Guizhou) of China. Chinese Sci. Bull. 12, 929-932 (in Chinese).

Lock, B.E., 1974. Stratigraphy of the volcanic rocks of the Barkley East district. Trans. Geol. Soc. S. Afr. 77, 117129.

Lock, B.E., 1978. Ultrahigh-temperature volcanic mudflows amongst the Drakensberg volcanic rocks: new criteria for their recognition. Trans. Geol. Soc. S. Afr. 81, 55-59.

Lorenz, V., 1986. On the growth of maars and diatremes and its relevance to the formation of tuff rings. Bull. Volcanol. 48, 265-274.

Lyle, P., 2000. The eruption environment of multi-tiered columnar basalt flows. J. Geol. Soc. (Lond.) 157, 715722.

Mahoney, J.J., 1988. Deccan Traps. In: J.D. Macdougall (Ed.), Continental Flood Basalts. Kluwer Academic Publishers, Dordrecht, pp. 151-194.

Mahoney, J.J., Fitton, J.G., Wallace, P.J., 2003. The Ontong Java Plateau: insights from recent ODP drilling [abstract], IUGG 2003, Sapporo, Japan, pp. A.211.

Marathe, S.S., Kulkarni, S.R., Karmarkar, B.M., Gupte, R.B., 1981. Variations in the nature of Deccan Trap Volcanicity of Western Maharashtra in Time and Space. In: K.V. Subbarao, and R.N. Sukeswala (Eds.), Deccan Volcanism and Related Basalt Provinces in other parts of the World. Geol. Soc. India Memoir 3, pp. 143-152.

Marsh, J.S., Eales, H.V., 1984. The chemistry and petrogenesis of igneous rocks of the Karoo central area, Southern Africa. In: A.J. Erlank (Ed.), Petrogenesis of the volcanic rocks of the Karoo Province. Special Pub. Geol. Soc. S. Afr., pp. 27-67.
Marsh, J.S., Skilling, I., 1998. Field Excursion Guide Book A3: Karoo volcanic and intrusive rocks, Eastern Cape, IAVCEI International Volcanology Conference, Cape Town, South Africa.

Marsh, J.S., Hooper, P.R., Rehacek, J., Duncan, R.A., Duncan, A.R., 1997. Stratigraphy and age of Karoo basalts of Lesotho and implications for correlations within the Karoo igneous province. In: J.J. Mahoney and M.F. Coffin (Eds.), Large Igneous Provinces: Continental, Oceanic, and Planetary Flood Volcanism. Am. Geophys. Union, Geophysical Monograph 100, pp. 247-272.

McClintock, M.K., 2001. Phreatomagmatism at Coombs Hills, Antarctica - Magma-water super-volcanism in a wet, failed rift. M.Sc. Thesis, University of Otago, Dunedin, New Zealand.

McClintock, M.K., White, J.D.L., submitted. Large phreatomagmatic vent complex at Coombs Hills, Antarctica: Wet, explosive initiation of flood basalt volcanism in the Ferrar-Karoo LIP. Bull. Volcanol.

McClintock, M.K., Houghton, B.F., Skilling, I.P., White, J.D.L., 2002. The volcaniclastic opening phase of Karoo flood basalt volcanism: Drakensberg Formation, South Africa [abstract]. EOS Trans. Am. Geophys. Union 83, F1445.

McClintock, M.K., Houghton, B.F., Skilling, I.P., White, J.D.L., 2003. Evolution of a large-volume explosive ventcomplex at the base of the Karoo LIP: Sterkspruit Complex, South Africa [abstract]. EOS Trans. Am. Geophys. Union 84, Fall Meet. Suppl., Abstract V52G-05.

Minor, D.R., Musaka, S.B., 1997. Zircon U-Pb and hornblende ${ }^{40} \mathrm{Ar}-{ }^{39} \mathrm{Ar}$ ages for the Dufek layered mafic intrusion, Antarctica: Implications for the age of the Ferrar large igneous province. Geochim. Cosmochim. Acta 61, 24972504.

Mitchell, A.A., Ramluckan, V.R., Dunlevey, J.N., Eglington, B.M., 1996. The basalt stratigraphy of the Sani Pass, Kwazulu/Natal Drakensberg. S. Afr. J. Geol. 99, 251-262.

Mohr, P., Zanettin, B., 1988. The Ethiopian flood basalt province. In: J.D. Macdougall (Ed.), Continental Flood Basalts, Kluwer Academic Publishers, Dordrecht, pp. 63111

Morrison, A.D., Reay, A., 1995. Geochemistry of Ferrar Dolerite sills and dykes at Terra Cotta Mountain, south Victoria Land, Antarctica. Antarctic Sci. 7, 73-85.

Mortimer, N., Parkinson, D., Raine, J.I., Adams, C.J., Graham, I.J., Oliver, P.J., Palmer, K., 1995. Ferrar magmatic province rocks discovered in New Zealand: Implications for Mesozoic Gondwana geology. Geology 23, 185-188.

Morton, A.C., Knox, R.W.O., 1990. Geochemistry of late Palaeocene and early Eocene tephras from the North Sea Basin. J. Geol. Soc. (Lond.) 147, 425-437.

Morton, A.C., Evans, D., Harland, R., King, C., Ritchie, D.K., 1988. Volcanic ash in a cored borehole W of the Shetland Islands: evidence for Selandian (late Palaeocene) volcanism in the Faeroes region. In: A.C. Morton and L.M. Parson (Eds.), Early Tertiary Volcanism and the Opening of the NE Atlantic. Geol. Soc. Special Pub. 39, pp. 263-269.

Musset, A.E., Dagley, P., Skelhorn, R.R., 1988. Time and duration of activity in the British Tertiary Igneous Province. In: A.C. Morton and L.M. Parson (Eds.), Early Tertiary Volcanism and the Opening of the NE Atlantic. Geol. Soc. Special Pub. 39, pp. 337-348.

Nielsen, O.B., Heilmann-Clausen, C., 1988. Palaeogene volcanism; the sedimentary record in Denmark. In: A.C. Morton and L.M. Parson (Eds.), Early Tertiary volcanism and the opening of the NE Atlantic. Geol. Soc. Special Pub. 39, pp. 395-405.

Nielsen, T.D.F., Soper, N.J., Brooks, C.K., Faller, A.M., Higgins, A.C., Matthews, D.W., 1981. The pre-basaltic 
sediments and the Lower Basalts at kangerlussuaq, East Greenland: their stratigraphy, lithology, paleomagnetism and petrology. Meddelelser om Grønland, Geosciences 6, $1-25$

Noe-Nygaard, A., Rasmussen, J., 1968. Petrology of a 300 metre sequence of basaltic lavas in the Faeroe Islands. Lithos 1, 286-304.

Pankhurst, R.J., Leat, P.T., Sruoga, P., Rapela, C.W., Márquez, M., Storey, B.C., Riley, T.R., 1998. The Chon Aike province of Patagonia and related rocks in West Antarctica: A large silicic igneous province. J. Volcanol. Geotherm. Res. 81, 113-136.

Pankhurst, R.J., Riley, T.R., Fanning, C.M., Kelley, S.P., 2000. Episodic silicic volcanism in Patagonia and the Antarctic Peninsula: chronology of magmatism associated with the break-up of Gondwana. J. Petrol. 41, 605-625.

Patterson, E.M., 1963. Tertiary vents in the northern part of the Antrim plateau, Ireland. Quart. J. Geol. Soc. London 119, 419-443.

Peate, D.W., 1997. The Paraná-Etendeka province. In: J.J. Mahoney and M.F. Coffin (Eds.), Large Igneous Provinces: Continental, Oceanic, and Planetary Flood Volcanism. Am. Geophys. Union, Geophysical Monograph 100, pp. 217-245.

Pedersen, A.K., Jørgensen, K.A., 1981. A textural study of basaltic tephras from lower Tertiary diatomites in Northern Denmark. In: S. Self and R.S.J. Sparks (Eds.), Tephra Studies. Reidel, Dordrecht, pp. 213-218.

Pedersen, A.K., Dueholm, K.S., 1992. New methods for the geological analysis of Tertiary volcanic formations in Nuussuaq and Disko, central West Greenland, using multi-model photogrammetry. In: K.S. Dueholm and A.K. Pedersen (Eds.), Geological analysis and mapping using multi-model photogrammetry. Rapport Grønlands Geologiske Unders $\varnothing$ gelse 156, 19-34.

Pedersen, A.K., Engell, J., Rønsbo, J.G., 1975. Early Tertiary volcanism in the Skagerrak: new chemical evidence from ash-layers in the Mo-clay of northern Denmark. Lithos 8, 255-268.

Pedersen, A.K., Watt, M., Watt, W.S., Larsen, L.M., 1997. Structure and stratigraphy of the Early Tertiary basalts of the Blosseville Kyst, East Greenland. J. Geol. Soc. (Lond.) 154, 565-570.

Pedersen, A.K., Larsen, L.M., Riisager, P., Dueholm, K.S., 2002. Rates of volcanic deposition, facies changes and movements in a dynamic basin; the Nuussuaq Basin, West Greenland, around the C27n-C26r transition. In: D.W. Jolley and B.R. Bell (Eds.), The North Atlantic igneous province; stratigraphy, tectonic, volcanic and magmatic processes. Geol. Soc. Special Pub. 197, pp. 157-181.

Planke, S., Symonds, P.A., Alvestad, E., Skogseid, J., 2000. Seismic volcanostratigraphy of large-volume basaltic extrusive complexes on rifted margins. J. Geophys. Res. $105,19,335-19,351$

Preston, J., 1982. Eruptive volcanism. In: D.S. Sutherland (Ed.), Igneous Rocks of the British Isles. John Wiley \& Sons, Chichester, pp. 351-368.

Puchtel, I.S., Hofmann, A.W., Mezger, K., Jochum, K.P., Shchipansky, A.A., Samsonov, A.V., 1998. Oceanic plateau model for continental crustal growth in the Archaean: A case study from the Kostomuksha greenstone belt, NW Baltic Shield. Earth Planet. Sci. Lett. 155, 57-74.

Raghavendra Rao, V., 1975. Data on the subsurface distribution of Deccan Trap. J. Geol. Soc. India 16, 373-377.

Raja-Rao, C.S., Shahasrabudne, Y.S., Deshmukh, S.S., Raman, R., 1999. Distribution, structure and petrography of the Deccan Traps. In: K.V. Subbarao (Ed.), Deccan volcanic province, Geol. Soc. India Memoir 43, pp. 401-414.

Ramanathan, S., 1981. Some aspects of Deccan volcanism of western Indian Shelf and Cambay Basin. In: K.V.
Subbarao and R.N. Sukeswala (Eds.), Deccan Volcanism and Related Basalt Provinces in other parts of the World. Geol. Soc. India Memoir 3, pp. 198-217.

Rampino, M.R., Stothers, R.B., 1988. Flood basalt volcanism during the past 250 million years. Science 241, 663-668.

Rampino, M.R., Self, S., 2000. Volcanism and biotic extinctions. In: Sigurdsson, H., Houghton, B., McNutt, S.R., Rymer, H., Stix, J. (Eds.), Encyclopedia of Volcanoes. Academic Press, London, pp. 1083-1091.

Reffay, A., 1979. Le volcanisme explosif sur la côte septentrionale du Plateau d'Antrim (Irlande du Nord). Publication de l'Institut de Géographie de la Faculté de Clermont-Ferrand LVIII, 57-67.

Reffay, A., 1983. Mise en question du volcanisme explosif sur la côte septentrionale du Plateau d'Antrim (Irlande du Nord). Norois 118, 279-284.

Reffay, A., 1987. Cavités karstiques et coulées de lave sur le pourtour du Plateau d'Antrim (Irlande du Nord). Travaux U.A. du CNRS 16, 51-56.

Reichow, M.K., Saunders, A.D., White, R.V., Pringle, M.S., Al'Mukhamedov, A.I., Medvedev, A.I., Kirda, N.P., 2002. ${ }^{40} \mathrm{Ar} /{ }^{39} \mathrm{Ar}$ dates from the West Siberian Basin: Siberian flood basalt province doubled. Science 296, 1846-1849.

Renne, P.R., Zichao, Z., Richards, M.A., Black, M.T., Basu, A.R., 1995. Synchrony and causal relations between Permian-Triassic boundary crises and Siberian flood volcanism. Science 269, 1413-1416.

Renne, P.R., Glen, J.M., Milner, S.C., Duncan, A.R., 1996. Age of Etendeka flood volcanism and associated intrusions in southwestern Africa. Geology 24, 659-662.

Reubi, O., Ross, P.-S., White, J.D.L., 2005. Debris avalanche deposits associated with Large Igneous province volcanism: an example from the Mawson Formation, Central Allan Hills, Antarctica. Geol. Soc. Am. Bull. (in press)

Riisager, P., Hall, S., Andretter, M., Zhao, X., 2004. Early Cretaceous Pacific paleomagnetic pole from Ontong Java. In: J.G. Fitton, J.J. Mahoney, P.J. Wallace and A.D. Saunders (Eds.), Origin and evolution of the Ontong Java Plateau. Geol. Soc. Special Pub. 229, pp. 31-44.

Riley, T.R., Knight, K.B., 2001. Age of pre-break-up Gondwana magmatism. Antarctic Sci. 13, 99-110.

Riley, T.R., Leat, P.T., Pankhurst, R.J., Harris, C., 2001. Origins of large volume rhyolitic volcanism in the Antarctic Peninsula and Patagonia by crustal melting. J. Petrol. 42, 1043-1065.

Ross, P.-S., 2005. Volcanology of the Mawson Formation at Coombs and Allan Hills, South Victoria Land, Antarctica. PhD Thesis, University of Otago, Dunedin, New Zealand.

Ross, P.S., White, J.D.L., 2003a. Discontinuous volcanic eruptions in a phreatomagmatic vent complex: Coombs Hills, South Victoria Land. Can. Antarctic Res. Network Newlett. 16, 4-6.

Ross, P.S., White, J.D.L., 2003b. Basaltic explosive eruptions in the Ferrar LIP [abstract], IUGG 2003, Sapporo, Japan, pp. A.212.

Ross, P.-S., White, J.D.L., 2004. Jurassic phreatomagmatism in the Ferrar large igneous province, Antarctica [abstract], IAVCEI General Assembly. IAVCEI, Pucon, Chile.

Ross, P.-S., White, J.D.L., in prep. Mafic, large-volume, pyroclastic density current deposits from phreatomagmatic eruptions in the Ferrar large igneous province, Antarctica. J. Geol.

Saunders, A.D., Tarney, J., Kerr, A.C., Kent, R.W., 1996. The formation and fate of large oceanic igneous provinces. Lithos 37, 81-95.

Saunders, A.D., Fitton, J.G., Kerr, A.C., Norry, M.J., Kent, R.W., 1997. The North Atlantic Igneous Province. In: J.J. Mahoney and M.F. Coffin (Eds.), Large Igneous Provinces: Continental, oceanic, and planetary flood 
volcanism. Am. Geophys. Union, Geophysical Monograph 100, pp. 45-93.

Sethna, S.F., 1981. Geology around Bombay-some intriguing problems. In: K.V. Subbarao and R.N. Sukeswala (Eds.), Deccan Volcanism and Related Basalt Provinces in other parts of the World. Geol. Soc. India Memoir 3, pp. 87-92.

Sethna, S.F., 1999. Geology of Mumbai and surrounding areas and its position in the Deccan Traps stratigraphy. J. Geol. Soc. India 53, 359-365.

Sharma, M., 1997. Siberian Traps. In: J.J. Mahoney and M.F. Coffin (Eds.), Large Igneous Provinces: Continental, Oceanic, and Planetary Flood Volcanism. Am. Geophys. Union, Geophysical Monograph 100, pp. 273-295.

Shipboard Scientific Party, 2001. Site 1184. In: J.J. Mahoney, J.G. Fitton, P.J. Wallace and 23 others (Eds.), Proceedings of the Ocean Drilling Program, Initial Reports [CD-ROM] Leg 192, pp. 1-131.

Shukla, P.N., Venkatesan, T.R., Bhandari, N. 1988. Chemistry and chronology of traps and intertrappeans from Takli, Nagpur. In: K.V. Subbarao (Ed.), Deccan Flood Basalts. Geol. Soc. India Memoir 10, pp. 213-223.

Singh, S.D., 2000. Petrography and clay mineralogy of Intertrappean Beds of Mumbai, India. J. Geol. Soc. India, $55,275-288$

Sigurdsson, H., 1990. Evidence of volcanic loading of the atmosphere and climate response. Palaeogeogr., Palaeoclim., Palaeoecol. 89, 277-289.

Sigurdsson, H., Loebner, B., 1981. Deep-sea record of Cenozoic explosive volcanism in the North Atlantic. In: Self, S., Sparks, R.S.J., (Eds.), Tephra Studies. D. Reidel Publishing Co., 289-316.

Single, R.T., Jerram, D.A., Pearson, D.G., Hobbs, R., 2003. Field observations of flood basalt structure: implications for offshore interpretation and sub-volcanic investigation, EGS-AGU-EUG Joint Assembly, 6-11 April 2003, Nice, France, abstract 5777.

Sørensen, A.B., 2003. Cenozoic basin development and stratigraphy of the Faroes area. Petroleum Geosci. 9, 189207.

Soper, N.J., Higgins, A.C., Downie, C., Matthews, D.W., Brown, P.E., 1976. Late Cretaceous-Early Teritary stratigraphy of the kangerdlugssuaq area, East Greenland, and the age of the opening of the North-East Atlantic. J. Geol. Soc. (Lond.) 132, 85-104.

Srinivasan, R., Jaffri, S.H., Rao, G.V., Reddy, G.K., 1998. Phreatomagmatic eruptive center from the Deccan Trap Province, Jabalpur, central India. Current Science (India) 74, 787-790.

Stewart, K., Turner, S., Kelley, S., Hawkesworth, C., Kirstein, L., Mantovani, M., 1996. 3-D, ${ }^{40} \mathrm{Ar}-{ }^{39} \mathrm{Ar}$ geochronology in the Parana continental flood basalt province. Earth Planet. Sci. Lett. 143, 95-109.

Storey, M., Duncan, R.A., Larsen, H.C., Waagstein, R., Larsen, L.M., Tegner, C., Lesher, C.E., 1996. Impact and rapid flow of the Icelandic plume beneath Greenland at $61 \mathrm{Ma}$ [abstract]. EOS Trans. Am. Geophys. Union 77(46), 839.

Stothers, R.B., 1993. Flood basalts and extinction events. Geophys. Res. Lett. 20, 1399-1402.

Swanson, D.A., Wright, T.L., 1981. The regional approach to studying the Columbia River Basalt Group. In: K.V. Subbaroa and R.N. Sukheswala (Eds.), Deccan volcanism and related basalt provinces of the world. Geol. Soc. India Memoir 3, pp. 58-80.

Swanson, D.A., Wright, T.L., Helz, R.T., 1975. Linear vent systems and estimated rates of magma production and eruption for the Yakima Basalt on the Columbia Plateau. Am. J. Sci. 275, 877-905.

Tegner, C., Duncan, R.A., Bernstein, S., Brooks, C.K., Bird, D.K., Storey, M., 1998. ${ }^{40} \mathrm{Ar} /{ }^{39} \mathrm{Ar}$ geochronology of Tertiary mafic intrusions along the East Greenland rifted margin - relation to flood volcanism and the Icelandic hotspot. Earth Planet. Sci. Lett. 156, 75-88.

Thompson, G.M., Ali, J.R., Song, X., Jolley, D.W., 2001. Emeishan Basalts, SW China: reappraisal of the formation's type area stratigraphy and a discussion of its significance as a large igneous province. J. Geol. Soc. (Lond.) $158,593-599$.

Thordarson, T., 2004. Accretionary-lapilli-bearing pyroclastic rocks at ODP Leg 192 Site 1184: a record of subaerial phreatomagmatic eruptions on the Ontong Java Plateau. In: J.G. Fitton, J.J. Mahoney, P.J. Wallace and A.D. Saunders (Eds.), Origin and evolution of the Ontong Java Plateau. Geol. Soc. Special Pub. 229, pp. 275-306.

Thordarson, T., Self, S., 1993. The Laki (Skaftár Fires) and Grímsvötn eruptions in 1783-1785. Bull. Volcanol. 55, 233-263.

Thordarson, T., Self, S., 1996. Sulfur, chlorine, and fluorine degassing and atmospheric loading by the Roza eruption, Columbia River Basalt Group, Washington, USA. J. Volcanol. Geotherm. Res. 74, 49-73.

Thordarson, T., Self, S., 2003. Atmospheric and environmental effects of the 1783-1784 Laki eruption: A review and reassessment. Journal of Geophysical Research Atmospheres 108, art. no. 4011.

Tolan, T.L., Reidel, S.P., Beeson, M.H., Anderson, J.L., Fecht, K.R., Swanson, D.A., 1989. Revisions to the estimates of the areal extent and volume of the Columbia River Basalt Group. In: S.P. Reidel and P.R. Hooper (Eds.), Volcanism and tectonism in the Columbia River flood-basalt province. Geol. Soc. Am. Special Paper 239, pp. 1-20.

Ukstins, I.A., Renne, P.R., Wolfenden, E., Baker, J.A., Ayalew, D., Menzies, M.A., 2002. Matching conjugate rifted margins: ${ }^{40} \mathrm{Ar} /{ }^{39} \mathrm{Ar}$ chrono-stratigraphy of pre- and syn-rift bimodal flood volcanism in Ethiopia and Yemen. Earth Planet. Sci. Lett. 198, 289-306.

Ukstins Peate, I., Larsen, M., Lesher, C.E., 2003a. The transition from sedimentation to flood volcanism in the Kangerlussuaq Basin, East Greenland: basaltic pyroclastic volcanism during initial Palaeogene continental break-up. J. Geol. Soc. (Lond.) 160, 759-772.

Ukstins Peate, I., Baker, J.A., Kent, A.J.R., Al-Kadasi, M., AlSubbary, A., Ayalew, D., Menzies, M., 2003b. Correlation of Indian Ocean tephra to individual Oligocene silicic eruptions from Afro-Arabian flood volcanism. Earth Planet. Sci. Lett. 211, 311-327.

Ukstins Peate, I., Baker, J.A., Al-Kadasi, M., Al-Subbary, A., Knight, K.B., Riisager, P., Thirlwall, M.F., Peate, D.W., Renne, P.R., Menzies, M.A., in press. Volcanic stratigraphy of large-volume silicic pyroclastic eruptions during Oligocene Afro-Arabian flood volcanism in Yemen. Bull. Volcanol.

Viereck, L.G., Taylor, P.N., Parson, L.M., Morton, A.C., Hertogen, J., Gibson, I.L., and the ODP Leg 104 Scientific party, 1988. Origin of the Palaeogene Vøring Plateau volcanic sequence. In: A.C. Morton and L.M. Parson (Eds.), Early Tertiary Volcanism and the Opening of the NE Atlantic. Geol. Soc. Special Pub. 39, pp. 69-83.

Visser, J.N.J., 1984. A review of the Stormberg Group and Drakensberg volcanics in Southern Africa. Paleontol. Afr. 25, 5-27.

Viswanathan, S., Chandrasekharam, D., 1981. Geochemical comparison of the Siberian and Deccan Traps. In: K.V. Subbaroa and R.N. Sukheswala (Eds.), Deccan volcanism and related basalt provinces of the world. Geol. Soc. India Memoir 3, pp. 460-471.

Waagstein, R., Hald, N., 1984. Structure and petrography of a $660 \mathrm{~m}$ lava sequence from the Vestmanna-1 drill hole, lower and middle basalt series, Faeroe Islands. In: O. Berthelsen, A. Noe-Nygaard and J. Rasmussen (Eds.), The 
deep drilling project 1980-1981 in the Faeroe Islands. Annales Societas Scientarum Fœroensis 1984, 39-70.

Waagstein, R., Heilmann-Clausen, C., 1995. Petrography and biostratigraphy of Palaeogene volcaniclastic sediments dredged from the Faeroes shelf. In: R.A. Scrutton, M.S. Stoker, G.B. Schimmield and A.W. Tudhope (Eds.), The tectonics, sedimentation, and palaeoceanography of the North Atlantic region. Geol. Soc. Special Pub. 90, pp. 179-197.

Waagstein, R., Hald, N., Jørgensenn, O., Nielsen, P.H., NoeNygaard, A., Rasmussen, J., Schonharting, G., 1984. Deep drilling on the faeroe Islands. Bull Geol. Soc. Denmark 32, 133-138.

Wager, L.R., 1934. Geological investigations in East Greenland. Part I: General geology from Angmagsalik to Kap Dalton. Meddelelser om Grønland 104, 1-46.

Wager L.R., 1935. Geological investigations in East Greenland. Part II: Geology of Kap Dalton. Meddelelser om Grønland $105,1-42$.

Wager L.R., 1947. Geological investigations in East Greenland. Part 4: The stratigraphy and tectonics of Knud Rasmussens Land and the Kangerdlugsuaq region. Meddelelser om Grønland 134, 1-64.

Walker, G.P.L., 1971. Compound and simple lava flows and flood basalts. Bull. Volcanol. 35, 579-590.

Walker, G.P.L., 1999. Some observations and interpretations of the Deccan Traps. In: K.V. Subbarao (Ed.), Deccan Volcanic Province, Geol. Soc. India Memoir 43, pp. 367395.

Wallace, P., Anderson, A.T., 2000. Volatiles in magmas. In: H. Sigurdsson, B. Houghton, S.R. McNutt, H. Rymer and J. Stix (Eds.), Encyclopedia of Volcanoes. Academic Press, London, pp. 149-170.

Watkeys, M.K., 2002. Development of the Lebombo rifted volcanic margin of southeast Africa. In: M.A. Menzies, S.L. Klemperer, C.J. Ebinger and J. Baker (Eds.), Volcanic Rifted Margins. Geol. Soc. Am. Special Paper 362, pp. 27-46.

White, J.D.L., Houghton, B., 2000. Surtseyan and related phreatomagmatic eruptions. In: Sigurdsson, H., Houghton, B., McNutt, S.R., Rymer, H., Stix, J. (Eds.), Encyclopedia of Volcanoes. Academic Press, London, pp. 495-511.

White, J.D.L., McClintock, M.K., 2001. Immense vent complex marks flood-basalt eruption in a wet, failed rift: Coombs Hills, Antarctica. Geology 29, 935-938.

White, R.V., Saunders, A.D., 2005. Volcanism, impact and mass extinctions: incredible or credible coincidences? Lithos 79, 299-316.
White, R.V., Godard, M., Fitton, J.G., Neal, C.R., Castillo, P.R., 2004. Phreatomagmatic eruptions on the Ontong Java Plateau: Chemical and isotopic relationship to Ontong Java Plateau basalts. In: J.G. Fitton, J.J. Mahoney, P.J. Wallace and A.D. Saunders (Eds.), Origin and evolution of the Ontong Java Plateau. Geol. Soc. Special Pub. 229, pp. 307-323.

Widdowson, M., Kelley, S., 2003. Late stage explosive volcanism in the Deccan CFBP [abstract]. Mantle plumes: Physical processes, chemical signatures, biological effects, University of Wales, Cardiff.

Widdowson, M., Walsh, J.N., Subbarao, K.V., 1997. The geochemistry of Indian bole horizons; palaeoenvironmental implications of Deccan intravolcanic palaeosurfaces. In: M. Widdowson (Ed.), Palaeosurfaces; recognition, reconstruction and palaeoenvironmental interpretation. Geol. Soc. Special Pub. 120, pp. 269-281.

Widdowson, M., Pringle, M.S., Fernandez, O.A., 2000. A post K-T boundary (early Palaeocene) age for Deccan-type feeder dykes, Goa, India. J. Petrol. 41, 1177-1194.

Wignall, P.B., 2001. Large igneous provinces and mass extinctions. Earth-Sci. Rev. 53, 1-33.

Wilson, M.G.C., 1988. The mineral resources of South Africa, Sixth edition. Council for Geoscience, South Africa, 740 pp.

Xiao, L., Xu, Y.-G., Chung, S.-L., He B., Mei, H.J., 2003. Chemostratigraphic correlation of Upper Permian lava succession from Yunnan Provinc, China: Extent of the Emeishan large igneous province. Int. Geol. Rev. 45, 753766.

Xu, Y.-G., Chung, S.-L., Jahn, B.M., Wu, G.Y., 2001. Petrologic and geochemical constrains on the petrogenesis of Permia-Triassic Emeishan flood basalts in southwestern China. Lithos 58, 145-168.

Zhang, Y.X., Luo, Y., Yang, X., 1988. The Panxi Rift. Geological Press, Beijing.

Zhou, M.F., Malpas, J., Song, X.Y., Robinson, P.T., Sun, M., Kennedy, A.K., Lesher, C.M., Keays, R.R., 2002. A temporal link between the Emeishan large igneous province (SW China) and the end-Guadalupian mass extinction. Earth Planet. Sci. Lett. 196, 113-122.

Zolotukhin, V.V., Al'mukhamedov, A.I., 1988. Traps of the Siberian Platform. In: J.D. Macdougall (Ed.), Continental Flood Basalts. Kluwer Academic Publishers, Dordrecht, pp. 273-310. 
Table 1. Age, preserved surface areas (A), preserved volumes (V) and importance of mafic volcaniclastic deposits (MVDs) for the flood volcanic provinces discussed herein, from youngest to oldest

\begin{tabular}{|c|c|c|c|c|}
\hline Province & $\begin{array}{l}\text { Age } \\
\text { (Ma) }\end{array}$ & $\begin{array}{c}\mathrm{A} \\
\left(10^{6} \mathrm{~km}^{2}\right)\end{array}$ & $\begin{array}{c}\mathrm{V} \\
\left(10^{6} \mathrm{~km}^{3}\right)\end{array}$ & MVDs \\
\hline $\begin{array}{l}\text { Columbia River } \\
\text { (USA) }\end{array}$ & $17-6^{[1]}$ & $0.16^{[2]}$ & $0.175^{[2]}$ & Minor \\
\hline $\begin{array}{l}\text { Afro-Arabia } \\
\text { (Yemen-Ethiopia) }\end{array}$ & $31-25^{[3-4]}$ & $0.6^{[5]}$ & $0.35^{[5]}$ & Minor \\
\hline North Atlantic & $62-55^{[6]}$ & $1.3^{[7]}$ & $6.6^{[7]}$ & Locally imp. \\
\hline $\begin{array}{l}\text { Deccan Traps } \\
\text { (mainly India) }\end{array}$ & $65.5^{[8]}$ & $\begin{array}{l}0.5^{[9]} \\
0.8^{[10]}\end{array}$ & $\begin{array}{l}0.5-1^{[11]} \\
>1.5^{[7]}\end{array}$ & Minor \\
\hline $\begin{array}{l}\text { Ontong-Java Plateau } \\
\text { (Pacific Ocean) }\end{array}$ & $\sim 122^{[12]}$ & $1.86^{[12]}$ & $8.4^{[12]}$ & Locally imp. \\
\hline $\begin{array}{l}\text { Paraná-Etendeka } \\
\text { (Brazil-Namibia) }\end{array}$ & $134-129^{[13]}$ & $1.5^{[13]}$ & $>1^{[13]}$ & None known \\
\hline $\begin{array}{l}\text { Ferrar } \\
\text { (mainly Antarctica) }\end{array}$ & $183-180^{[14]}$ & $0.15^{[15]}$ & $0.3^{[15]}$ & Locally imp. \\
\hline $\begin{array}{l}\text { Karoo } \\
\text { (mainly S. Africa) }\end{array}$ & $183-180^{[14]}$ & $\sim 2^{[16]}$ & $?$ & Minor \\
\hline $\begin{array}{l}\text { Siberian Traps } \\
\text { (Russia) }\end{array}$ & $250^{[17]}$ & $\begin{array}{l}1.5^{[18,19]} \\
3.9^{[20]}\end{array}$ & $\begin{array}{l}0.9^{[19]} \\
>2^{[20]}\end{array}$ & Major constituent \\
\hline $\begin{array}{l}\text { Emeishan } \\
\text { (SW China) }\end{array}$ & $\begin{array}{l}253-250^{[21]} \\
\sim 259^{[22]}\end{array}$ & $0.25^{[21,23,24]}$ & $\begin{array}{l}<0.25^{[25]} \\
\sim 0.3^{[26]}\end{array}$ & Locally imp. \\
\hline $\begin{array}{l}\text { Eastern Pilbara } \\
\text { (Australia) }\end{array}$ & $\begin{array}{l}\text { Late } \\
\text { Achaean }{ }^{[27]}\end{array}$ & $0.11^{[27]}$ & $?$ & Important \\
\hline
\end{tabular}

References and notes: [1] Hooper (1997); [2] Tolan et al. (1989); [3] Baker et al. (1996); [4] Ukstins et al. (2002); [5] Mohr and Zanettin (1988); [6] Saunders et al. (1997); [7] Eldholm \& Grue (1994); [8] Hofmann et al. (2000); [9] measured on figure 12; [10] Devey and Lightfoot (1986); [11] Widdowson et al. (2000); [12] Coffin and Eldholm (1994); [13] Peate (1997); [14] Riley and Knight (2001); [15] see Table 3; [16] interpolation between lava outcrops shown on figure 7a; [17] Sharma (1997); [18] Zolotukhin and Al'mukhamedov (1988), Siberian platform only; [19] see Table 4; [20] Reichow et al. (2002); includes extension to the west of figure 8a; [21] Xu et al. (2001); [22] Zhou et al. (2002); [23] He et al. (2003); includes the area shown on figure 13a only; [24] Huang and Opdyke (1998); [25] Ali et al. (2002) quote a figure of $0.25 \times 10^{6} \mathrm{~km}^{3}$ and cite [24] has the source of this volume, but [24] give only a surface area; figure 13a shows that lava thickness $\geq 1 \mathrm{~km}$ are only very locally reached, so the mean thickness has to be $<1 \mathrm{~km}$; [26] Ali et al. (2005), assuming a mean thickness of $700 \mathrm{~m}$ and including extensions of the province not shown on figure 13a; [27] Blake (2001). 
Table 2. Mafic volcaniclastic deposits (MVDs) in the North Atlantic Igneous Province not described in the text, by region from west to eas

\begin{tabular}{|c|c|c|}
\hline Region & Description of MVDs & Interpretation \\
\hline $\begin{array}{l}\text { West } \\
\text { Greenland }\end{array}$ & $\begin{array}{l}\text { Hyaloclastite successions interlayered with marine sediments (Pedersen \& Dueholm, 1992; Pedersen et al., } \\
\text { 2002); distal tuffs intercalated with shales in basins surrounding lavas \& hyaloclastites (Larsen et al., 1992). }\end{array}$ & $\begin{array}{l}\text { Lava flows entering the sea for the hyaloclastite deltas; not enough in formation for } \\
\text { the tuffs. }\end{array}$ \\
\hline Hatton Bank & $\begin{array}{l}\text { Tholeiitic basalts at Site } 552 \text { (DSDP Leg 81) overlain by early Eocene sediments interbedded with "abundant } \\
\text { tuffs" (chemistry not mentioned) (Saunders et al., 1997). }\end{array}$ & Not enough detail in description. \\
\hline $\begin{array}{l}\text { Offshore } \\
\text { Faeroe } \\
\text { Islands }\end{array}$ & $\begin{array}{l}\text { Well to moderately sorted, locally crudely bedded basaltic tuffs of probable latest Paleocene age dredged E of } \\
\text { Faeroes, from stratigraphic unit poss. } 400 \mathrm{~m} \text { thick overlying youngest Faeroes lavas (Waagstein \& Heilmann- } \\
\text { Clausen, 1995). Most of basaltic ash (formerly blocky sideromelane) altered to palagonite; vesicularity } \\
\text { variable but generally <50\%. Also, hyaloclastite deltas based on seismic profiles (e.g., Sørensen, 2003; Single } \\
\text { et al, 2003) in the Faeroe-Shetland basin. }\end{array}$ & $\begin{array}{l}\text { The basaltic tuffs originated by phreatomagmatism, were deposited in a non-marine } \\
\text { environment, and the tephra was reworked (Waagstein \& Heilmann-Clausen, 1995). }\end{array}$ \\
\hline \multirow[t]{2}{*}{$\begin{array}{l}\text { Shetland } \\
\text { Islands } \\
\text { (offshore) }\end{array}$} & $\begin{array}{l}\text { 2- Commercial wells (219/28-1 \& } 219 / 28-2) \sim 170 \mathrm{~km} \mathrm{NNE} \text { of Shetlands intercepted ash-rich interval } \\
\text { ( } 91 / 104 \mathrm{~m} \text { thick, respecti vely) equivalent to Sele \& Balder fms (Fitch et al., 1988). Begins with } 3 \mathrm{~m} \text { of MVDs, } \\
\text { overlain by ash-rich siltstones \& mudstones. "Primary ashfalls" are "mostly basaltic and lithic-vitric in } \\
\text { character". Above "ash-marker", a further } 284 / 396 \mathrm{~m} \text { (respectively) of ash-bearing Eocene sediments are found. }\end{array}$ & $\begin{array}{l}\text { 2- In Well 219/28-2, "undoubted primary basic ashfall tuff" exist based on side-wall } \\
\text { cores (Fitch et al., 1988). However, volcaniclastics are mostly re-sedimented, as } \\
\text { evidenced by the "admixture and interdigitation of silty or sandy detritus with the } \\
\text { volcanic component". }\end{array}$ \\
\hline & $\begin{array}{l}\text { 1- British Geol. Surv. borehole } 82 / 12, \sim 115 \mathrm{~km} \text { WSW from the Shetlands: late Paleocene tuff layer }(1 \mathrm{~cm} \text { thick } \\
\text { max.) containing angular non-vesicular high-Ti tholeiitic basaltic glass shards (Morton et al., } 1988) \text {. Chemistry } \\
\text { of glass compatible with Faeroes-E Greenland province (specifically correlated with Faeroes lower lava series). }\end{array}$ & $\begin{array}{l}\text { 1- Correlated with phase } 1 \text { of Knox \& Morton (1983) in the North Sea (Morton et al., } \\
\text { 1988). The description of the tephra suggests preatomagmatic fragmentation (this } \\
\text { review). }\end{array}$ \\
\hline Ireland & $\begin{array}{l}\text { Antrim plateau: the coastline near the Giant's Causeway has } 20 \text { exposures of 'agglomerate' (vent-filling breccia) } \\
\& \text { tuff (Patterson, 1963). The vents cut through limestone country rocks \& basaltic lavas. Basaltic fragments } \\
\leq 6 \mathrm{~m} \text { across + Lias mudstone clasts (from under the chalk) are seen in the agglomerates. Example: } \\
\text { Carrickarade vent, } 275 \mathrm{~m} \text { diameter, surrounded by a } 60 \mathrm{~m} \text { high tuff cone (Preston, } 1982 \text { ). }\end{array}$ & $\begin{array}{l}\text { Diatreme-like vent-filling breccias, surrounded by tuff cones, have a plau sible } \\
\text { phreat omagmatic origin (Preston, 1982; this review). Reffay (1979, 1983,1987) } \\
\text { doubts that all Patterson's (1963) MVD exposures are real: some could be altered or } \\
\text { structurally-deformed basalt flows. }\end{array}$ \\
\hline $\begin{array}{l}\text { Northern } \\
\text { Skye }\end{array}$ & $\begin{array}{l}\text { In the Hebrides, most volcaniclastic deposits are silicic but Tertiary lavas are locally underlain by basaltic ash } \\
\text { layers (Bell \& Emeleus, 1988). N Skye shows } 25 \mathrm{~m} \text { of palagonite tuffs which in places "resemble } \\
\text { agglomerates". MVDs are largely composed of angular sideromelane clasts (up to block-size); small clasts \& } \\
\text { the margins of larger ones are altered to palagonite (Anderson \& Dunham, 1966). }\end{array}$ & $\begin{array}{l}\text { The MVDs underlying the lavas were deposited in shallow lakes (Drever \& Dunham, } \\
\text { 1969), and have a phretomagmatic ori gin (Preston, 1982). }\end{array}$ \\
\hline Central Skye & $\begin{array}{l}450 \mathrm{~m} \text { thick, poorly sorted (structureless?) MVDs fill a } 2 \mathrm{~km}^{2} \text { vent (Jassim \& Gass, } 1970 \text { ). The vent-fill is } \\
\text { composed mainly of sub-angular basaltic and gabbroic clasts; also contains huge slabs of gabbro }(40-900 \mathrm{~m} \\
\text { long) derived from the vent walls \& "rafts" (average } 10 \mathrm{~m} \text { across) of bedded tuff. The latter resemble in texture } \\
\text { "fine-grained and well-layered" tuffs forming two "thick horizons" (now tilted) in the vent. }\end{array}$ & $\begin{array}{l}\text { The bedded tuffs are interpreted by Jassim \& Gass (1970) as pyroclastic fall deposits; } \\
\text { the origin of the poorly sorted (structureless?) MVDs less clear, but they resemble } \\
\text { diatreme-like vent-filling deposits at Coombs Hills in the Ferrar province (White \& } \\
\text { McClintock, 2001). }\end{array}$ \\
\hline $\begin{array}{l}\text { Vøring } \\
\text { Plateau }\end{array}$ & $\begin{array}{l}\text { ODP Leg } 104 \text {, Site } 642 \text { cored through a } 900 \mathrm{~m} \text {-thick volcanic sequence (Viereck et al., 1988). Upper Series } \\
\text { include } 53 \text { mostly basaltic "lithic vitric tuff beds", } \leq 7 \mathrm{~m} \text { thick (gen. }<10 \mathrm{~cm} \text { thick), representing } ~ 4 \% \text { of total } \\
\text { thickness. Basaltic clasts consist of sub-equal amounts of former sideromelane and tachylitic to } \\
\text { microcrystalline clasts, with an average vesicularity }<50 \text { vol. \%. Presence of accretionary lapilli in two beds. }\end{array}$ & $\begin{array}{l}\text { The tuffs were reworked based on "repetitive fining-upward sequences and internal } \\
\text { erosional surfaces"; eruptions were subaerial (accretionary lapilli); the fragmentation } \\
\text { was phreatomagmatic, and the areal distribution is more typical of Plinian eruptions; } \\
\text { chemical similarities suggest a correlation with the North Sea (Viereck et al., 1988). }\end{array}$ \\
\hline
\end{tabular}

Abbreviations: DSDP, Deep Sea Drilling Program; MVDs, mafic volcaniclastic deposits; ODP, Ocean Drilling Program. 
Table 3. Surface areas (A) and volumes (V) of the components of the Ferrar province in Antarctica

\begin{tabular}{lccccc}
\hline \multirow{2}{*}{ Component } & \multicolumn{2}{c}{$\mathrm{A}\left(10^{3} \mathrm{~km}^{2}\right)$} & & \multicolumn{2}{c}{$\mathrm{V}\left(10^{3} \mathrm{~km}^{3}\right)$} \\
\cline { 2 - 3 } \cline { 6 - 7 } Dufek intrusion(s) & Expos. & Infer. & & Expos. & Infer. \\
Ferrar Dolerite & $150^{[3]}$ & $450^{[4]}$ & & $110^{[5]}$ & $170^{[5]}$ \\
Kirkpatrick Basalt & $?$ & $195^{[6]}$ & & $.8^{[5]}$ & $70^{[5]}$ \\
Prebble Fm (CTM) & $?$ & $.8^{[7]}$ & & $?$ & $.1^{[7]}$ \\
Mawson Fm (SVL) & $.07^{[8]}$ & $4.1^{[9]}$ & & $.02^{[8]}$ & $.25^{[10]}$ \\
Exposure Hill Fm (NVL) & $?$ & $.3^{[11]}$ & & $?$ & $.01^{[11]}$ \\
Total & $?$ & $?$ & & $?$ & $\sim 300$ \\
\hline
\end{tabular}

References and notes: [1] Ferris et al. (1998); [2] Elliot et al. (1999) - this assumes a 8-9 km thickness discredited by [1], so the correct volume is unknown; [3] length of $2000 \mathrm{~km}$ and a mean width $75 \mathrm{~km}$, measured on a georeferenced version of figure 6a; [4] length $3000 \mathrm{~km}$ and mean width $150 \mathrm{~km}$, as assumed by [5]; [5] Fleming et al. (1997); [6] length $1300 \mathrm{~km}$ (Otway Massif to Mesa Range) and mean width $150 \mathrm{~km}$ (mean width probably too large); [7] rough calculation from published sketches and thickness (Hanson and Elliot, 1996; Elliot and Hanson, 2001), with interpolation between measured sections within specific regions, but no interpolation between regions; [8] calculated from digitised, georeferenced maps and sketches from Grapes et al. (1974), Korsch (1984), Isaac et al. (1996), Elliot et al. (1997), and McClintock (2001); [9] interpolation between exposures from Prince Albert Mountains to Shapeless Mountain $(195 \mathrm{~km}) ;[10]$ assumes a mean thickness of $60 \mathrm{~m}$, which is a minimum; [11] rough calculation from published sketch and thickness (Elliot et al., 1986), method as [7].

Abbreviations: Fm, Formation; CTM, Central Transantarctic Mountains; NVL, North Victoria Land; SVL, South Victoria Land

Table 4. Spatial distribution of "traps" on the Siberian platform *

\begin{tabular}{lcccc}
\hline Facies & $\begin{array}{c}\text { Area } \\
\times 10^{3} \mathrm{~km}^{2}\end{array}$ & $\begin{array}{c}\text { Thickness } \\
\mathrm{km}\end{array}$ & $\begin{array}{c}\text { Volume } \\
\times 10^{3} \mathrm{~km}^{3}\end{array}$ & $\begin{array}{c}\text { Volume } \\
\text { \% of total }\end{array}$ \\
\hline $\begin{array}{l}\text { 'Intrusive' } \\
\text { (mostly sills) }\end{array}$ & 1500 & $\begin{array}{c}0-1.5 \\
\text { (ave. } 0.25)\end{array}$ & 337.5 & 37.05 \\
$\begin{array}{l}\text { 'Extrusive' } \\
\text { (lavas) }\end{array}$ & 337.5 & $\begin{array}{c}0-2.0 \\
\text { (ave. } 1.00)\end{array}$ & 337.5 & 37.05 \\
$\begin{array}{l}\text { 'Explosive' } \\
\text { (mostly MVDs) }\end{array}$ & 675 & $\begin{array}{c}0-0.7 \\
\text { (ave. } 0.35)\end{array}$ & 236 & 25.90 \\
TOTAL & 1500 & N/A & 911 & 100.00 \\
\hline
\end{tabular}

* Based on Viswanathan and Chandrasekharam (1981); excludes possible extensions of the province west of the area shown in figure $8 \mathrm{a}$. 
Table 5. Summary of mafic volcaniclastic deposits (MVDs) in some other flood basalt provinces, from youngest to oldest

\begin{tabular}{|c|c|c|}
\hline Province & Description of MVDs & Interpretation \\
\hline \multirow[t]{3}{*}{$\begin{array}{l}\text { Columbia } \\
\text { River Basalts } \\
\text { (Fig. 9) }\end{array}$} & $\begin{array}{l}\text { 3- Possible phreatomagmatic vent infills. Along Snake River (Asotin, Washington-Idaho boundary } \\
\text { area; Fig. 9, star c), a series of } 12 \text { elongated vents mapped in zone } \sim 16 \mathrm{~km} \text { long } \&<1.6 \mathrm{~km} \text { wide } \\
\text { (Fuller, 1928). These vents cross-cut earlier lava flows, flare upwards into crater shapes \& are filled in } \\
\text { part by glassy basaltic clasts (sideromelane altered to palagonite), intermingled with gravelly sediments. }\end{array}$ & $\begin{array}{l}\text { 3- Fuller (1928) inferred that vents were excavated } \\
\text { by phreatomagmatic explosions generated when } \\
\text { magma rising through fissures encountered water- } \\
\text { saturated gravels. }\end{array}$ \\
\hline & $\begin{array}{l}\text { 2- Pillow-palagonite complexes. Common at base of lava flows, especially near margins of Columbia } \\
\text { River plateau (Swanson \& Wright, 1981; Hooper, 1997). Lateral gradations between hyaloclastite } \\
\text { breccias \& coherent lavas also described (Lyle, 2000). }\end{array}$ & $\begin{array}{l}\text { 2- Pillow-palagonite complexes \& hyaloclastite } \\
\text { deltas formed when lava flows invaded water or wet } \\
\text { sediment (Hooper, 1997). }\end{array}$ \\
\hline & $\begin{array}{l}\text { 1- Proximal pyroclastic accumulations near linear vents. Accumulations of welded spatter \& } \\
\text { cinder/tuff cones documented along Roza vent system (Swanson et al., 1975; Thordarson \& Self, 1996). } \\
\text { Vent zones defined by thick beds }(>1 \mathrm{~m} \text { ) of spatter, pumice \& cinder of Roza lithology. Local remnants } \\
\text { of spatter cones and ramparts can be seen. Largest remnant }=\text { cone } 100-200 \mathrm{~m} \text { basal diameter (Fig. } 9 \text {, } \\
\text { star b). Source vents also documented for Ice Harbour type } 1 \text { flows (Fig. } 9 \text {, star a), where best exposed } \\
\text { vent area = "compound tuff cone more than } 200 \mathrm{~m} \text { in diameter and } 40 \mathrm{~m} \text { high" (Swanson et al., 1975). } \\
\text { There, crudely bedded tephra is poorly sorted, w/ lithics "sprinkled throughout the ejecta" (Swanson et } \\
\text { al., 1975). Basaltic fragments = relatively dense sideromelane clasts partially altered to palagonite. }\end{array}$ & $\begin{array}{l}\text { 1- Spatter cones \& ramparts: fire fountaining; tuff } \\
\text { cone with dense sideromelane clasts (altered to } \\
\text { palagonite) \& lithics: phreatomagmatic origin } \\
\text { (Swanson et al., 1975). }\end{array}$ \\
\hline \multirow[t]{3}{*}{$\begin{array}{l}\text { Afro-Arabia } \\
\text { (Figs. } 10 \& 11)\end{array}$} & $\begin{array}{l}\text { 3- Mafic mega-breccia in upper part of sequence in Yemen. In Escarpment \& Bayt Mawjan sections } \\
\text { (Figs. } 10 \& 11) \text {, mafic mega-breccia w/ clinopyroxene-bearing tuffaceous matrix \& megaclasts of } \\
\text { ignimbrite + basaltic lava }(5 \times 5 \times 10 \mathrm{~m}) \text { (Ukstins Peate et al., in press). }\end{array}$ & $\begin{array}{l}\text { 3- May be temporally related to caldera-collapse } \\
\text { breccia found in Sana' a area (Ukstins Peate, } \\
\text { unpublished). }\end{array}$ \\
\hline & $\begin{array}{l}\text { 2- Primary MVDs intercatated } w / \text { earliest lavas in Ethiopia \& Yemen. At Amba Aiba in northern } \\
\text { Ethiopia (Mohr \& Zanettin, 1988) \& Wadi Lahima in NW Yemen, } 1 \text { to }>5 \text { m-thick agglomerate \& tuff } \\
\text { layers are found. }\end{array}$ & 2- Not enough information. \\
\hline & $\begin{array}{l}\text { 1- MVDs overlying basement in NE Yemen Plateau. At Jabal Kura'a (Fig. 10), basement directly } \\
\text { overlain by } \sim 50 \mathrm{~m} \text { of thin beds ( } \mathrm{cm} \text { to } \mathrm{dm} \text { ), locally restricted \& exposed over area only } 10 \mathrm{~s} \text { of } \mathrm{m} \text { across; } \\
\text { some units contain abundant accretionary lapilli (Ukstins Peate et al., in press). }\end{array}$ & 1- Local phreatomagmatic activity? \\
\hline \multirow[t]{2}{*}{$\begin{array}{l}\text { Deccan Traps } \\
\text { (Fig. 12) }\end{array}$} & $\begin{array}{l}\text { 2- Pakistan. Late Cretaceous Parh Group: in central part of E-W outcrop belt, lava flows mostly } \\
\text { restricted to basal portion of sections (up to } 1.5 \mathrm{~km} \text { thick); bulk of sequence consists of volcaniclastic } \\
\text { deposits commonly interbedded with lava flows \& limestone units. Western \& eastern exposures } \\
\text { contain more lava flows, but still dominated by volcaniclastic deposits (Khan et al., 1999). }\end{array}$ & 2- Not enough information. \\
\hline & $\begin{array}{l}\text { 1. Deccan proper. Fine-grained deposits within or comprising 'intertrappean' beds (Das \& Dixit, 1972; } \\
\text { Ramanathan, 1981; Shukla et al., 1988; Widdowson et al., 1997; Raja-Rao et al., 1999). Both fine \& } \\
\text { coarse MVDs reported from base of lava sequence in Mumbai region (Marathe et al., 1981; Sethna, } \\
\text { 1981, 1999; Deshmukh, 1984; Singh, 2000) and less commonly elsewhere in western India (B lanford, } \\
\text { 1869; Walker, 1999). }\end{array}$ & $\begin{array}{l}\text { 1- In Mumbai region, some deposits interpreted as } \\
\text { products of phreatomagmatic activity triggered by } \\
\text { opening of India-Seychelles rift (Widdowson \& Kelly, } \\
\text { 2003); poorly sorted lapilli-tuffs containing armoured } \\
\text { lapilli in central India interpreted as phreatomagmatic } \\
\text { "vent-fills" (Srinivasan et al., 1998). }\end{array}$ \\
\hline
\end{tabular}

Table 5 (continued)

\begin{tabular}{|c|c|c|}
\hline Province & Description of MVDs & Interpretation \\
\hline $\begin{array}{l}\text { Emeishan (Fig. } \\
\text { 13) }\end{array}$ & $\begin{array}{l}\text { MVDs \& sedimentary rocks containing mafic lava fragments relatively widespread (Lin, 1985; Huang, } \\
\text { 1986; Cong 1988; Zhang et al., 1988), but volume probably }<10 \% \text { of province (Fig. 13c). Where } \\
\text { several volcanic cycles are present, each cycle begins w/ conglomerates \& other sed. rocks, followed by } \\
\text { thick basaltic lava flows \& ending w/ lava flows intercalated w/ fine-grained volcaniclastic deposits. } \\
\text { E.g., Binchuan: } 16 \text { cycles, including } ~ 1900 \text { m of volcaniclastic \& sed. rocks. Where only } 1 \text { volcanic } \\
\text { cycle exposed, volcaniclastic \& sed. rocks generally confined to lower part of sections, w/ thickness } \\
\text { ranging from zero at Qingyin to }>120 \mathrm{~m} \text { at Kunming (Fig. } 13 \mathrm{c} \text {, sections } 5-11 \text { ). } \\
\text { The conglomerates from Binchuan, Ertan \& Pingchuan contain fragments of both mafic lavas \& } \\
\text { limestone (Fig. 13d), whereas those from Huidong \& Qiaojia contain mainly limestone fragments } \\
\text { (upper Maokou Formation). }\end{array}$ & $\begin{array}{l}\text { Exact nature \& origin of volcaniclastic rocks largely } \\
\text { unknown. He et al. (2003) have proposed that } \\
\text { conglomerates \& related sedimentary rocks form an } \\
\text { alluvial fan associated w/ uplift of blocks in NE } \\
\text { flank of a domal structure. }\end{array}$ \\
\hline $\begin{array}{l}\text { Eastern Pilbara } \\
\text { Craton } \\
\text { (Western } \\
\text { Australia) }\end{array}$ & $\begin{array}{l}\text { Succession divided into } 11 \text { unconformity-bounded rock packages, with packages } 1,2 \text {, and } 4-10 \\
\text { including flood basalts (Blake, } 2001 \text { ). Package } 1 \text { basalts are present across the entire Pilbara Craton, } \\
\text { covering } \sim 1.1 \times 10^{5} \mathrm{~km}^{2} \text {. Subaerial basalts in packages } 5-10 \text { each underlain by MVDs. Geochemical data } \\
\text { suggest MVD-basalt couplets are genetically linked. Volcaniclastic units generally range from } 5 \text { to } \\
20 \mathrm{~m} \text { thick, but MVDs in package } 7 \text { are } ~ \\
\text { Mafic shards mostly dense \& formerly glassy w/ angular, sub-equant to equant shapes. Highly vesicular } \\
\text { shards rare to absent. Accretionary lapilli present in all volcaniclastic horizons except in package } 8 \text {. } \\
\text { Lithic fragments (incl. accidental fragments) are locally abundant. Dominant grain-size of mafic } \\
\text { (volcaniclastic) fraction varies from mud to medium sand, except in package } 7 \text { which includes pebble- } \\
\text { sized grains. Pillow basalts locally overlie MVDs in package } 9, \& \text { 'hyaloclastite complex' overlies } \\
\text { MVDs in package } 6 \text {. }\end{array}$ & $\begin{array}{l}\text { Acc. lap. indicate subaerial eruption plumes. Clast } \\
\text { assemblage \& morphology suggests } \\
\text { phreatomagmatic fragmentation, but most MVDs } \\
\text { have been reworked \& deposited in fluvio-lacustrine } \\
\text { environment, based on sedimentary structures } \\
\text { (Blake, 2001). Exceptions are MVDs of package } 8 \\
\text { which could be subaerial fall deposits \& those of } \\
\text { package } 7 \text { which could also include primary } \\
\text { volcaniclastic deposits. }\end{array}$ \\
\hline
\end{tabular}


Table 6. Summary of observations and interpretations regarding MVDs from flood volcanic provinces

\begin{tabular}{|c|c|c|c|c|c|c|c|c|c|c|c|c|}
\hline & $\begin{array}{l}\text { Columbia } \\
\text { River }\end{array}$ & $\begin{array}{l}\text { Afro- } \\
\text { Arabia }\end{array}$ & E Greenl. & $\begin{array}{l}\text { Ireland + } \\
\text { Skye }\end{array}$ & $\begin{array}{l}\text { North } \\
\text { Sea }\end{array}$ & Deccan & $\begin{array}{l}\text { Ontong- } \\
\text { Java }\end{array}$ & Ferrar & Karoo & Siberian & Emeishan & E Pilbara \\
\hline \multicolumn{13}{|l|}{ OBSERVATIONS } \\
\hline $\begin{array}{l}\text { Cumulative MVD thickness } \\
\text { locally }>100 \mathrm{~m}\end{array}$ & $\mathrm{x}$ & $\mathrm{x}$ & & $\checkmark$ & & $\checkmark$ & $\checkmark$ & $\checkmark$ & $\checkmark$ & $\checkmark$ & $\checkmark$ & $\checkmark$ \\
\hline Structureless deposits & & & $\checkmark$ & $\checkmark$ & & & & $\checkmark$ & $\checkmark$ & $\checkmark$ & & \\
\hline Layered deposits & $\checkmark$ & $\checkmark$ & $\checkmark$ & $\checkmark$ & $\checkmark$ & $\checkmark$ & $\checkmark$ & $\checkmark$ & $\checkmark$ & $\checkmark$ & $\checkmark$ & $\checkmark$ \\
\hline $\begin{array}{l}\text { Tuff-breccias and lapilli-tuffs } \\
\text { (including 'agglomerates') }\end{array}$ & $\checkmark$ & $\checkmark$ & $\checkmark$ & $\checkmark$ & $\mathrm{x}$ & $\checkmark$ & $\checkmark$ & $\checkmark$ & $\checkmark$ & $\checkmark$ & $\checkmark$ & \\
\hline Tuffs & $\checkmark$ & $\checkmark$ & $\checkmark$ & $\checkmark$ & $\checkmark$ & $\checkmark$ & $\checkmark$ & $\checkmark$ & $\checkmark$ & $\checkmark$ & $\checkmark$ & $\checkmark$ \\
\hline $\begin{array}{l}\text { Non-to poorly-vesicular blocky } \\
\text { sideromelane (or former basaltic } \\
\text { glass) clasts }\end{array}$ & $\checkmark$ & & $\checkmark$ & $\checkmark$ & $\checkmark$ & $\checkmark$ & $\checkmark$ & $\checkmark$ & $\checkmark$ & & & $\checkmark$ \\
\hline Vesicular basaltic clasts & $\checkmark$ & & $\checkmark$ & & & $\checkmark$ & $\checkmark$ & $\checkmark$ & $\checkmark$ & & & rare \\
\hline Abundant country rock fragments & $\checkmark$ & & $\checkmark$ & & & $\checkmark$ & & $\checkmark$ & $\checkmark$ & $\checkmark$ & $\checkmark$ & $\checkmark$ \\
\hline Quartz grains (ash fraction) & & & $\checkmark$ & & & & & $\checkmark$ & $\checkmark$ & & & \\
\hline Presence of accretionary lapilli & & $\checkmark$ & $\checkmark$ & & & $\checkmark$ & $\checkmark$ & $\checkmark$ & $\checkmark$ & & & $\checkmark$ \\
\hline \multicolumn{13}{|l|}{ INTERPRETATIONS } \\
\hline Primary volcaniclastic deposits & $\checkmark$ & & $\checkmark$ & $\checkmark$ & $\checkmark$ & $\checkmark$ & $\checkmark$ & $\checkmark$ & $\checkmark$ & & & $\checkmark$ \\
\hline Reworking syn- or post-volcanism & $\checkmark$ & & $\checkmark$ & & $\checkmark$ & $\checkmark$ & & $\checkmark$ & $\checkmark$ & & & $\checkmark$ \\
\hline Vent-filling deposits & $\checkmark^{1}$ & & & $\checkmark$ & & $\checkmark$ & & $\checkmark$ & $\checkmark$ & & & \\
\hline Phreatomagmatic fragmentation & $\checkmark$ & & $\checkmark$ & $\checkmark$ & $\checkmark$ & $\checkmark$ & $\checkmark$ & $\checkmark$ & $\checkmark$ & & & $\checkmark$ \\
\hline 'Magmatic' fragmentation & $\checkmark$ & & & & & & & & $\checkmark$ & & & \\
\hline Subaerial eruptions & $\checkmark$ & & $\checkmark$ & $\checkmark$ & & & $\checkmark$ & $\checkmark$ & $\checkmark$ & & & $\checkmark$ \\
\hline Subaqueous eruptions & $\checkmark$ & & $\checkmark$ & & & & & & & & & \\
\hline Subaerial deposition & $\checkmark$ & $\checkmark$ & $\checkmark$ & $\checkmark$ & & & $\checkmark$ & $\checkmark$ & $\checkmark$ & $\checkmark$ & & \\
\hline Subaqueous deposition & $\checkmark$ & $\checkmark$ & $\checkmark$ & $\checkmark$ & $\checkmark$ & & & $\checkmark$ & $\checkmark$ & $\checkmark$ & & $\checkmark$ \\
\hline
\end{tabular}

$\checkmark=$ present; $\mathrm{x}=$ probably absent; left blank = insufficient information av ai lable; 1 = Asotin craters only; 2 = Gronau alkaline tuff. 


\section{Figures}

Fig. 1: Location of the flood volcanic provinces discussed in the text. Distribution of lavas and intrusions based on: Paraná-Etendeka, Coffin and Eldholm (1994); Karoo, Cox (1988); star for the Pilbara craton, Blake (2001); other provinces same as in the respective figures.

Fig. 2: North Atlantic Igneous Province. (a) Post-drift map of the western part of the province (not including Baffin Island in Canada) showing the flood lavas and sills onshore and offshore Greenland and the Faeroe Islands, plus the seaward-dipping reflector sequences in the Atlantic Ocean. A24, magnetic anomaly; DSDP, Deep Sea Drilling Program; GIR, Greenland-Iceland Ridge; ODP, Ocean Drilling Program. (b) Geological map of the Kangerlussuaq Basin area (East Greenland). Vent sites: (1) V\&M, Vandfaldsdalen and Mikis Formation (vent location based on lava packages thickening towards the north and regional volcanostratigraphic correlations); (2) HF, Hængefjeldet Formation and equivalent pyroclastic rocks (vent site identified during field studies and in photogrammetric profiles); (3) NFF, Nansen Fjord Formation; MLF, Milne Land Formation; GPF, Geikie Plateau Formation (some eruption sites for these formations were identified in photogrammetric profiles; Pedersen et al., 1997; Larsen et al., 1999; Hansen et al., 2002). (c) Selected stratigraphic sections in the lower lava series of East Greenland, see (b) for locations. (d) Pre-drift map of the eastern part of the province, showing the distribution of igneous rocks in the British Isles (BTIP, British Tertiary Igneous Province, excluding the intrusive centres, after Musset et al., 1988) and the Balder and Sele Formations plus correlatives in the North Sea and adjacent areas (after Knox and Morton, 1988). Phase 2b ashes (isopachs, in meters) correspond to the lower part of the Balder Formation in the North Sea, comprising Fe-Ti tholeiitic (basaltic) tuffs presumably derived from the Faeroes-Greenland area.

Fig. 3: Field photographs of primary mafic volcaniclastic deposits (MVDs) from East Greenland [a], the Ferrar province $[\mathrm{b}, \mathrm{c}]$, and the Karoo province [d, e, f]. (a) Bomb bed with a fluidal bomb and associated sag structure from impact (Ryberg Fjord, see Fig. 2b). Hammer is $45 \mathrm{~cm}$ long. (b) Detail of heterolithologic, poorly sorted, structureless lapillituff in the Coombs Hills vent complex (Mawson Formation) showing 1. Beacon sandstone clasts, 2. coal clasts (black, above the numbers), 3. basaltic fragments. Scale bar in $\mathrm{cm}$. (c) Basalt-rich tuff-breccia (right) intruding vertically into heterolithologic, poorly sorted, structureless lapilli-tuff. This is one of many cross-cutting zones of non-bedded volcaniclastic material, metres to tens of metres across, in the Coombs Hills vent complex. (d) Thick to very thickbedded lapilli-tuff and tuff succession illustrated in upper c. $90 \mathrm{~m}$ of stratigraphic column (position marked by a white line) at Narrow Water (see Fig. 7c); person circled for scale. The MVDs are capped by lavas. (e) View of polymict coarse lapilli-tuff from the Sterkspruit Complex, typical of the bulk of the MVDs within the Karoo. (f) Accretionary lapilli in medium, plane-parallel bed forming part of the medial to distal deposits surrounding the Sterkspruit Complex (see Fig. 7b for Karoo locations).

Fig. 4: Plane-polarized, transmitted light photomicrographs of MVDs from East Greenland [a, b, c], the Ferrar at Coombs Hills [d, e, f], and the Sterkspruit Complex in the Karoo [g, h]. (a) Phreatomagmatic tuff in the Vandfaldsdalen Formation (Fig. 2c) with 50\% quartz and calcite derived from underlying unconsolidated sandstones. An accretionary lapillus is outlined (core of altered basaltic ash and fine quartz grains; rim of fine ash). (b) Surge deposit in Ryberg Fjord (Fig. 2b) containing accretionary lapilli and some armoured lapilli (lower unit); upper unit is clast-supported and contains vesicular tachylite and palagonite grains. (c) Reticulite from a vesicular tuff found in the Nansen Fjord volcanic stratigraphy. (d) Lithic-rich, poorly sorted, structureless lapilli-tuff showing 1. large sandstone fragment (outlined), 2. detrital quartz, 3. dense basaltic clasts (former glass, now altered to brown clays). (e) Basalt-rich, poorly sorted, structureless lapilli-tuff, including clasts of $\mathbf{1}$. dense to incipiently vesicular former glassy basalt, 2 . moderately vesicular former glassy basalt (vesicles filled with zeolites), 3. mudstone, 4. fine sandstone, 5. detrital quartz grains, in 6. a zeolite cement. (f) Lapilli-tuff with more abundant detrital quartz and fine ash than (e); note the engulfed quartz grains in the large basaltic clast (centre). (g) \& (h) Coarse lapilli-tuff showing sub-round to angular grains of quartz (Q), sub-round to round clasts of tachylite $(\mathbf{T})$ and irregular altered sideromelane (juvenile) fragments $(\mathbf{J})$. Some of the larger sideromelane clasts include feldspar microlites (arrows).

Fig. 5. Map of the Ontong Java Plateau (bold outline), showing Ocean Drilling Program (ODP) Sites for Leg 192 (stars) and older ODP and Deep Sea Drilling Program (DSDP) sites that reached the 'basement' (dots), after Shipboard Scientific Party (2001). The High Plateau 'basement' rocks consists of mafic lavas. In contrast, Site 1184 in the Eastern Salient (white star) penetrated $338 \mathrm{~m}$ of MVDs but no lavas (see text for details).

Fig. 6: Ferrar province. (a) Map of Antarctica showing the distribution of the Ferrar Dolerite (sills and dikes, Jurassic) and co-extensive Beacon Supergroup (sedimentary rocks, Devonian-Triassic), after Hanson and Elliot (1996). MVD outcrops are scattered but overall co-extensive with the Kirkpatrick Basalt (flood lavas, Jurassic). CTM: Central Transantarctic Mountains, SVL: South Victoria Land, NVL: North Victoria Land; TAM: Transantarctic Mountains. (b) Summary stratigraphic sections showing flood lavas and MVDs (thickness after Elliot, 2000).

Fig. 7: Karoo province. (a) Map of southern Africa showing Karoo igneous and sedimentary rocks, after Marsh et al. (1997) and Wilson (1998). The Karoo Central Area is delimited by a bold dashed line. (b) Map of the outcrops 
comprising volcaniclastic deposits in the Karoo Central Area. (c) Thick succession at Narrow Water typical of the Karoo MVDs. Intercalated pahoehoe lavas, volcaniclastic sandstone and quartzofeldspathic sandstone in the lower part of the sequence replaced upsection by thick- to very thick-bedded lapilli-tuff, accretionary lapilli-tuff and tuff point to a gradual ramping-up of explosive volcanism that overlapped with input of fluvial and aeolian quartzofeldspathic sediment. Scale is the same for all three columns.

Fig. 8: Siberian Traps. (a) Map of the Permian-Triassic intrusions, lavas, and MVDs on the Siberian platform after Czamanske et al. (1998). Does not show possible extensions of the province to the west. Circled numbers indicate the general location (from Fedorenko et al., 1996; Fedorenko and Czamanske, 1997) of stratigraphic sections. River names in italics. (b) Summary stratigraphic sections for the Siberian Traps. Lithology after (1: Sharma (1997) \& Czamanske et al. (1998); 2 Arndt et al. (1998), see also Fedorenko and Czamanske (2000); 3 \& 4 Zolothukhin and Al'mukhamedov (1988) and Sharma (1997). The MVDs in 2 include a $>150 \mathrm{~m}$ sequence containing 'agglomerates' (Fedorenko and Czamanske, 1997).

Fig. 9: Map showing the distribution of Columbia River flood basalts (shaded) in northwest USA, after Hooper (1997). Heavy dashed lines marked "Chief Joseph dike swarm" represent the limits of this swarm, which includes several swarms including the Grande Ronde and Cornucopia. Approximate location of the linear vent zones for the Ice Harbour flows and Roza Member after Swanson et al. (1975). Stars represent the approximate locations of (a) a tuff cone associated with Ice Harbour type 1 flows (locality 16 of Swanson et al., 1975); (b) the largest remnant of a Roza spatter cone (locality 15 of Swanson et al., 1975); (c) possible phreatomagmatic vents along the Snake River near the town of Asotin (from Fuller, 1928).

Fig. 10: Geological map of the Sana'a area, Yemen, Afro-Arabian Province, modified after Kruck (1983). The Sana'a and Jabal Shahirah sections and the Jabal an Nabi Shuyab and Bayt Mawjan sections cover equivalent stratigraphic intervals.

Fig. 11: Schematic volcanic stratigraphy of flood volcanic units emplaced during Oligocene bimodal volcanism in northern Yemen. All stratigraphic sections are relative to the same vertical scale and have been arranged to reflect relative horizontal (E-W) distances as well as elevation differences among sections (see Fig. 10 for location). Esc Escarpment, BB - Bayt Baws, JS - Jabal Shahirah, SK - Shibam Kawkabam, WD - Wadi Dhar, JK - Jabal Kura'a. A further $150 \mathrm{~km}$ to the west in the coastal rift mountains, the Wadi Lahima section represents the oldest flood basalt lavas yet found in northern Yemen, and starts with approximately 20-30 m of laterally-variable MVDs, including bomb beds.

Fig. 12: Deccan Traps: map of the onland flood basalts in India, after Mahoney et al. (1988) and Bondre et al. (2004). Drilling in the Arabian Sea suggests that the Trap province is down-faulted along the western Indian coast and offshore (Raghavendra Rao, 1975), possibly covering an area equivalent to the onshore outcrop $\left(\sim 0.5 \times 10^{6} \mathrm{~km}^{2}\right)$. In the hatched areas on the map, compound Pahoehoe flows dominate over simple flows and volcaniclastic deposits (mostly intertrapean beds) are more abundant than elsewhere on the Deccan plateau (Walker, 1971; Mahoney, 1988; Duraiswami et al., 2003; Bondre et al., 2004). These observations and lava thickness patterns suggest that these areas are more 'proximal' relative to eruptive centres than are surrounding regions (Mahoney, 1988). MVDs are especially abundant near Mumbai and in Pakistan (see Table 5).

Fig. 13: Emeishan province. The volcanic succession uncomfortably overlies late Middle Permian carbonate rocks (the Maokou Formation) and is in turn covered by uppermost Permian and middle Triassic sediments. Some basalts and mafic intrusive complexes exposed in the Simao basin, northern Vietnam and Qiangtang terrain are possibly the dismembered parts of the Emeishan province (Chung et al., 1998; Xiao et al., 2003). (a) Map showing the distribution and thickness (isopachs) of the Permian volcanic sequence in China after Thompson et al. (2001). (b) More detailed map showing basalt outcrops and section locations (circled numbers), with the inner, intermediate and outer zones of the domal structure (extent of pre-flood basalt erosion of the Maokou Formation) shown by the dash bold lines (modified from He et al., 2003). $\mathrm{F}_{1}$-Longmenshan fault; $\mathrm{F}_{2}$-Ailaoshan-Red River fault; $\mathrm{F}_{3}$-Xiaojiang fault; $\mathrm{F}_{4}$-XichangQiaojia fault; F $F_{5}$ Jinhe fault. (c) Stratigraphic sections after Huang (1986), Cong (1988) and Y.G. Xu (unpublished data); the numbers under the section names refer to (i) the total section height and (ii) the cumulative thickness of volcaniclastic plus sedimentary deposits, respectively. (d) Illustration of a conglomerate containing both lava fragments and Maokou limestone clasts. See table 5 for more information.

Fig. 14. Schematic illustration summarizing the different positions that mafic volcaniclastic deposits (MVDs) can occupy in flood basalt provinces. 


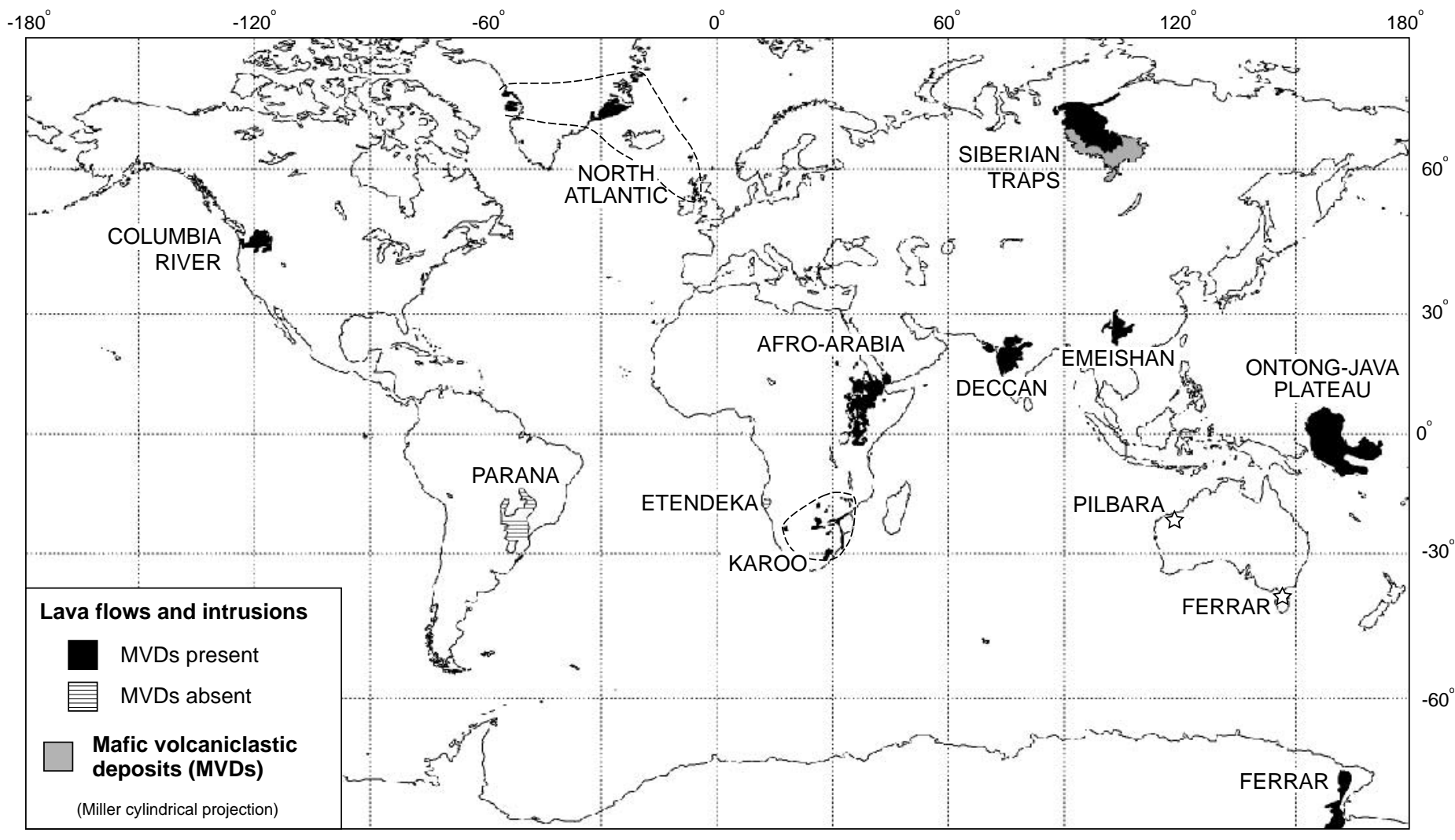

Ross et al., Fig. 1 
a

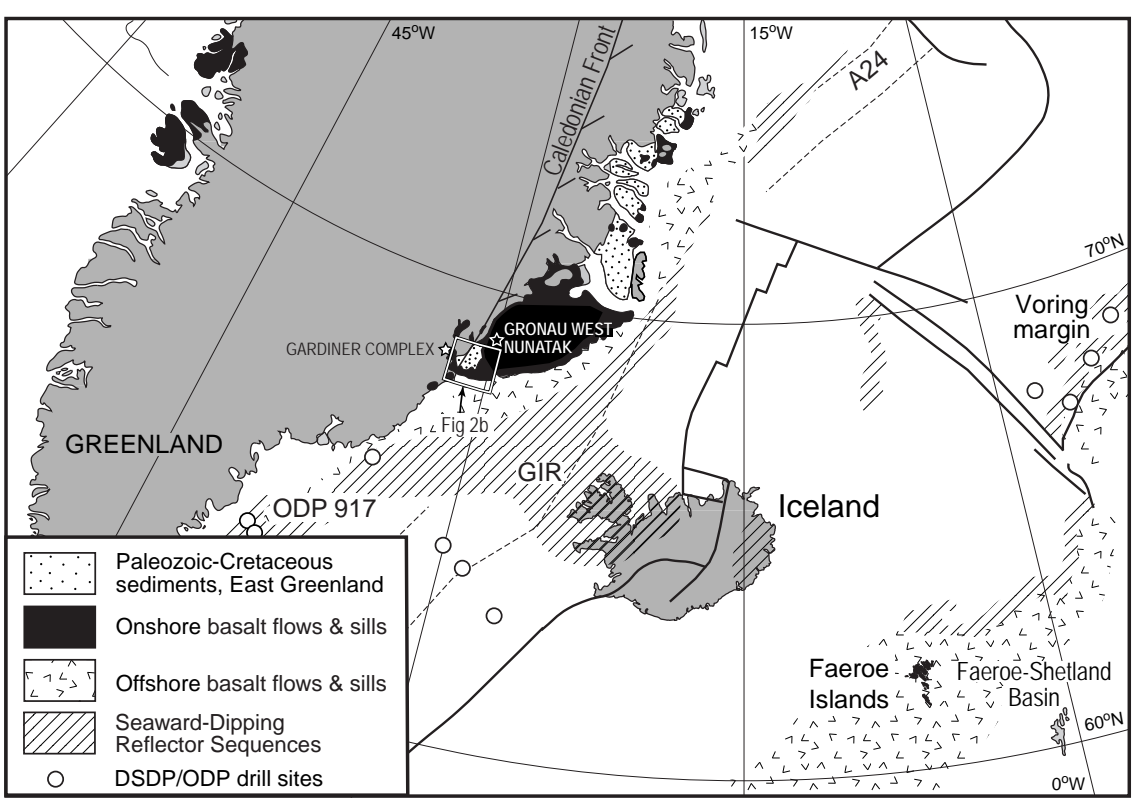

b

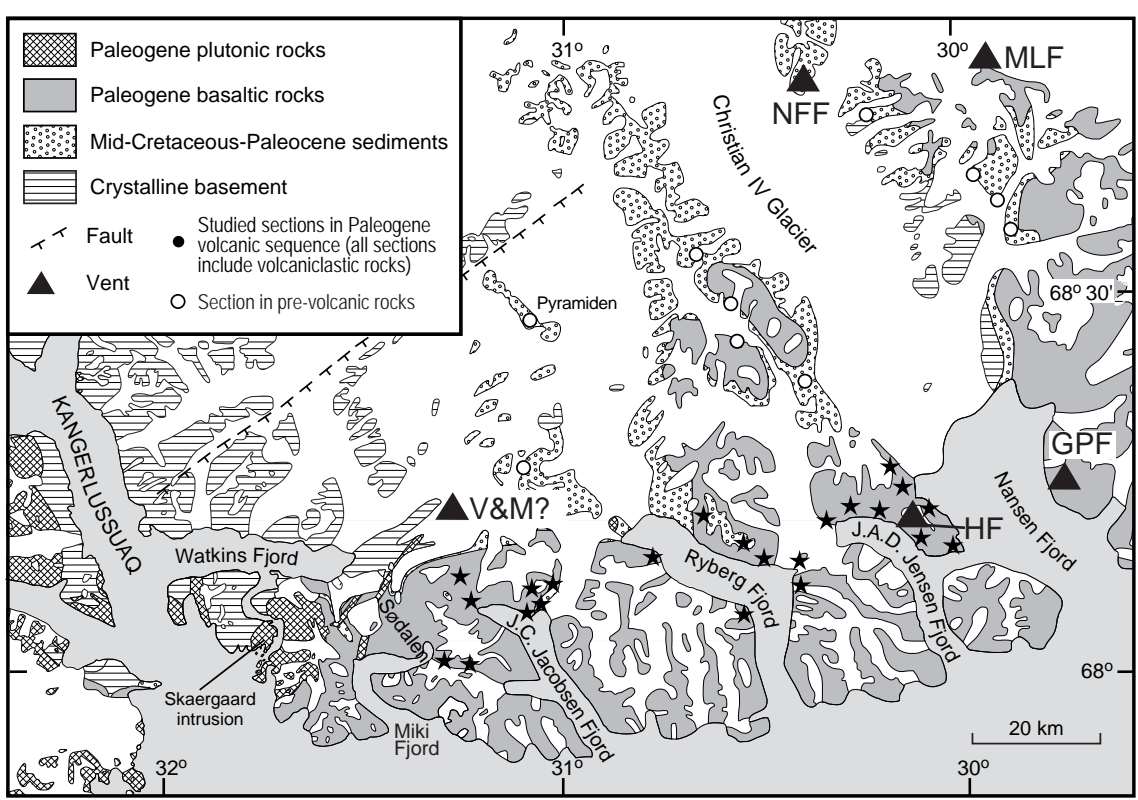

C

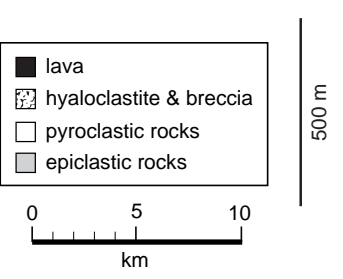

Haengefjeldet Fm. and Equivalent

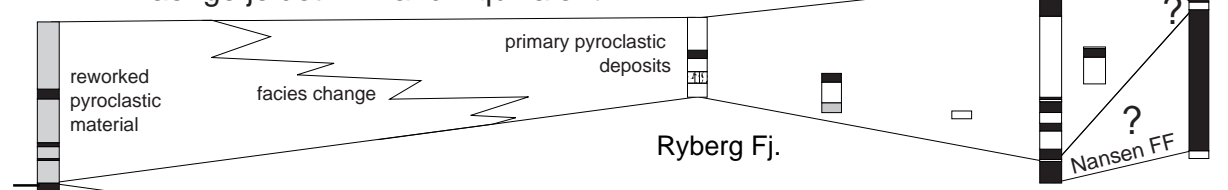

Jensen Fj. Nansen Fj.

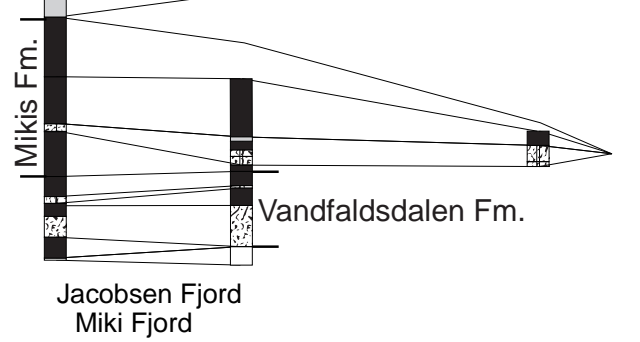

Miki Fjord

d

Total ash thickness (m), individ. sections

2.8 (phase 2b of Knox and Morton, 1988)

$\mathrm{c}=$ contaminated by detrital sediment

1- Postulated ash thickness $(m)$ with contamination and subaqueous redistribution removed

Balder and Sele Formations

plus correlatives

$\square \quad$ Flood basalts (BTIP)

BTIP dike swarm (simplified)

$1000 \mathrm{~km}$

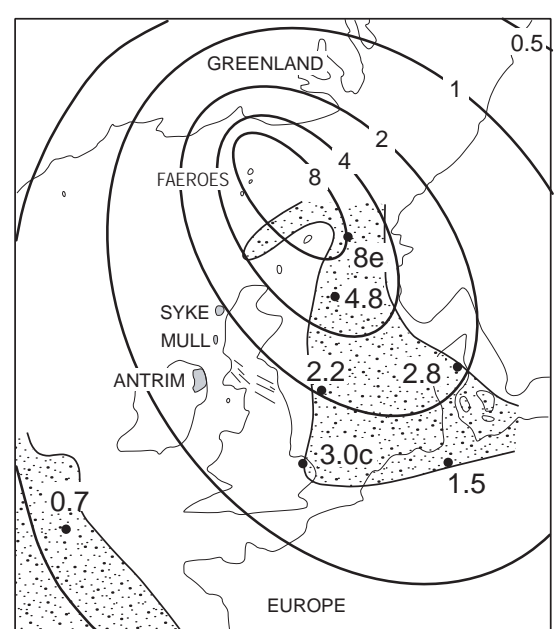

Ross et al., Fig. 2 


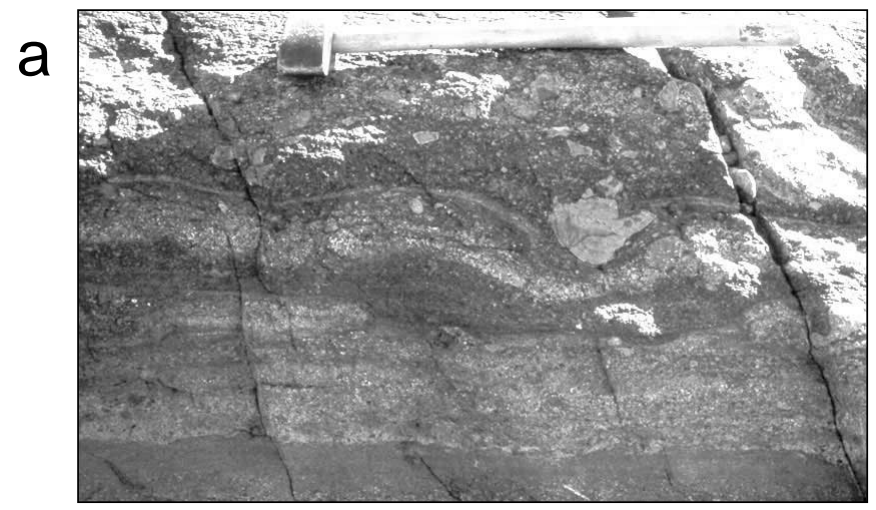

b

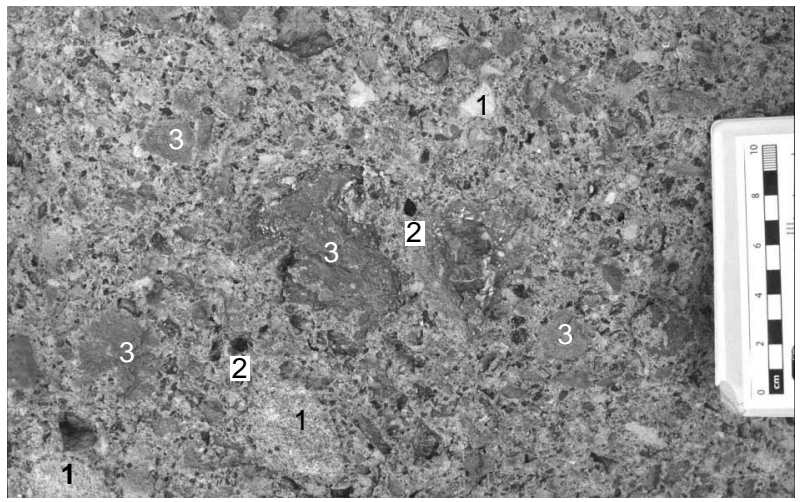

C

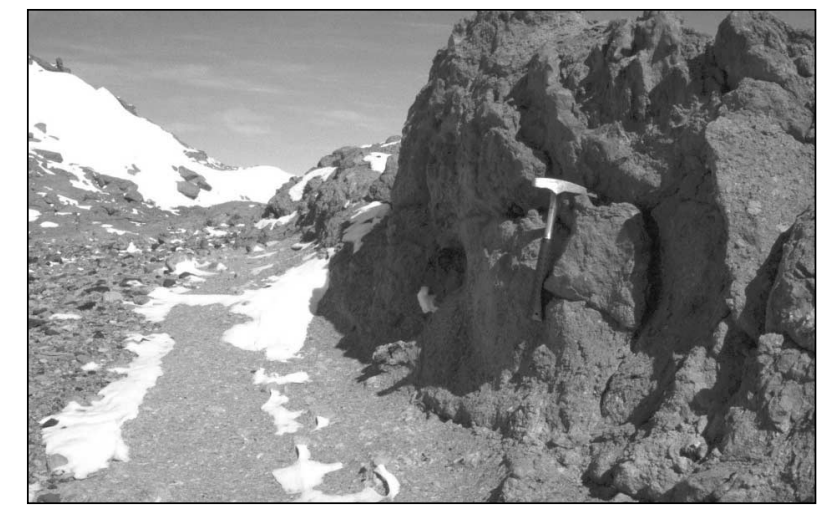

d

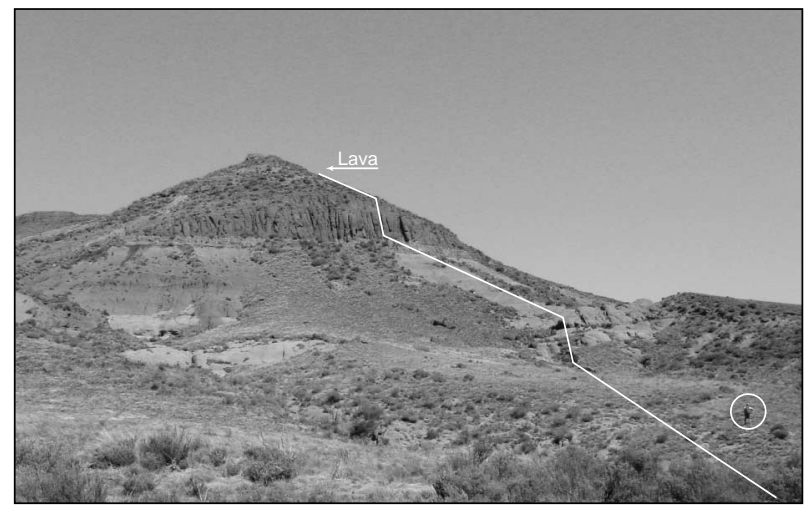

e

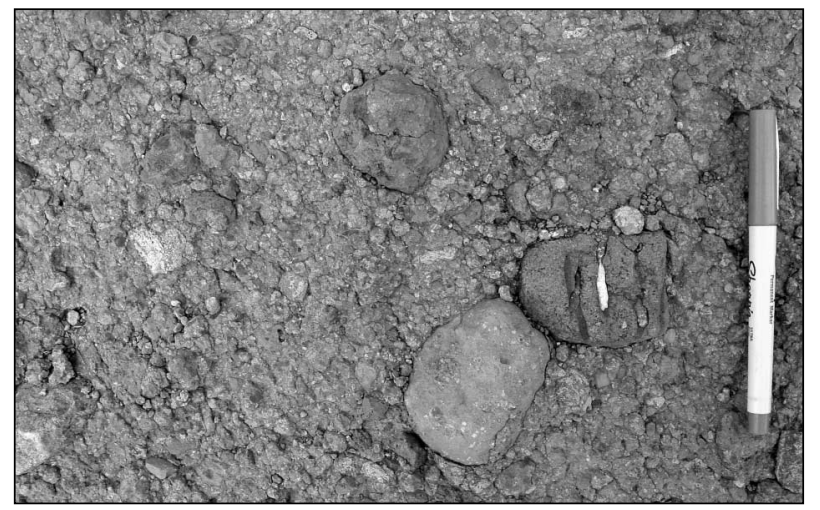

f

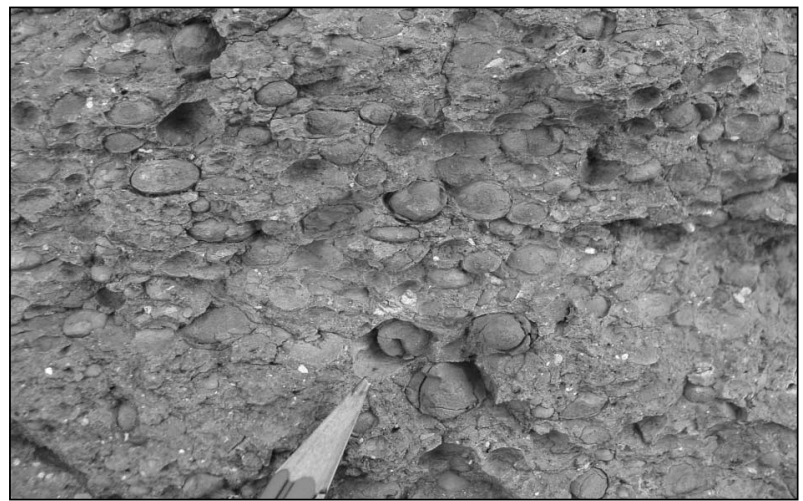

Ross et al., Fig. 3 
a

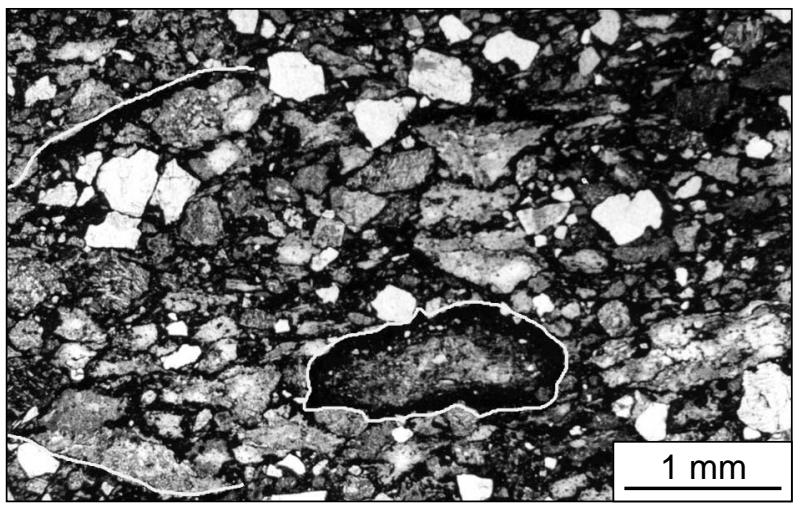

b

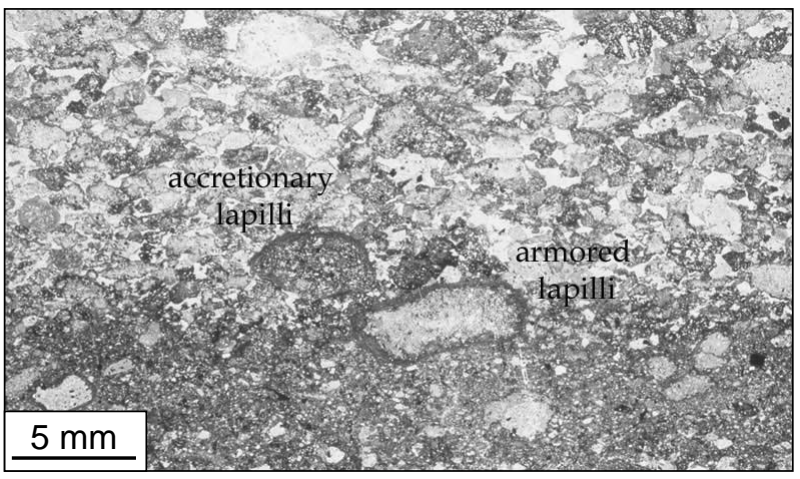

C

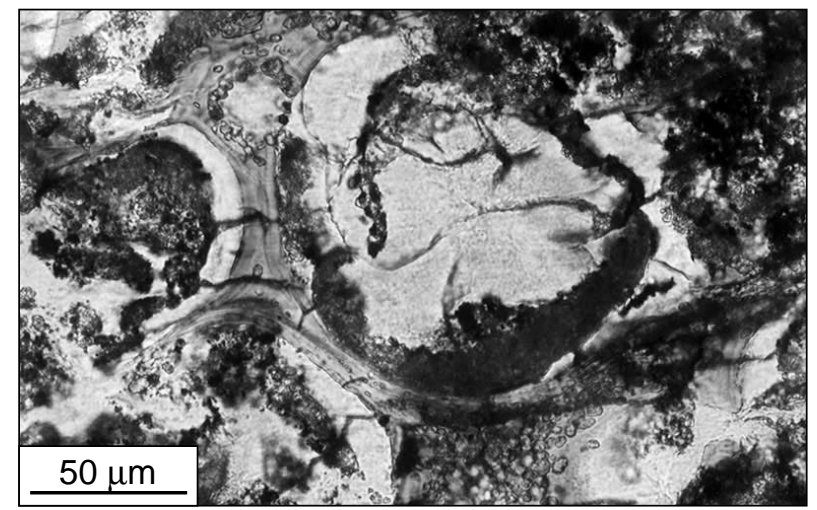

d

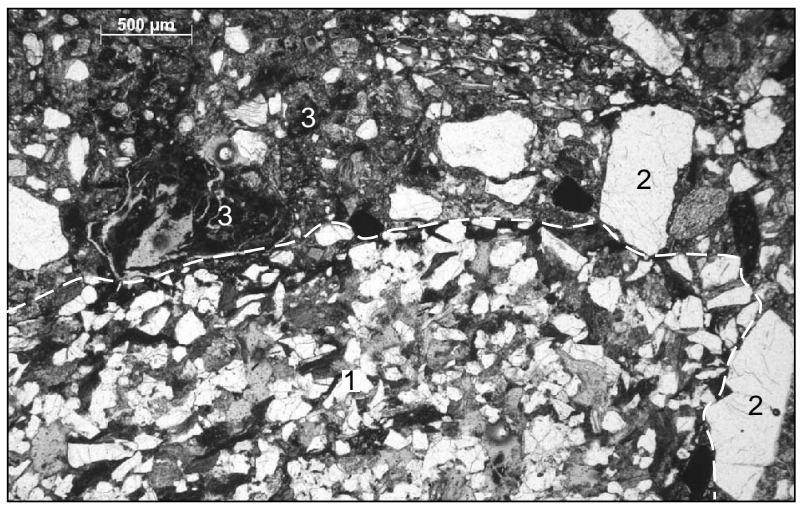

e

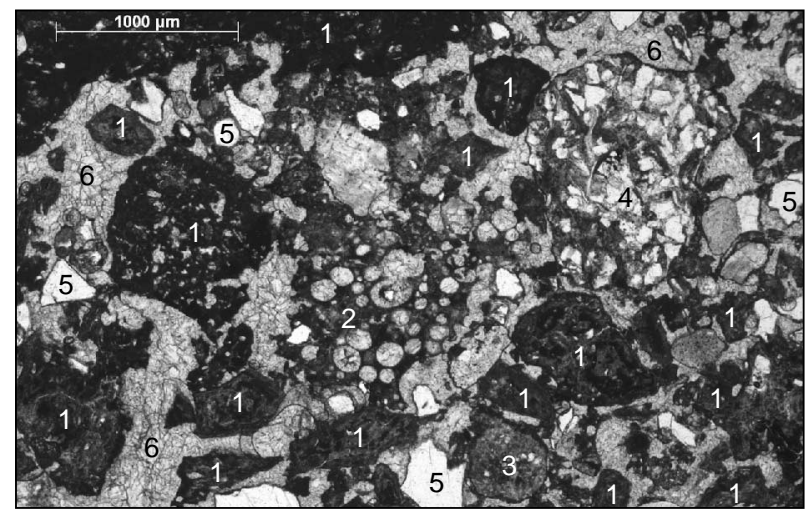

f

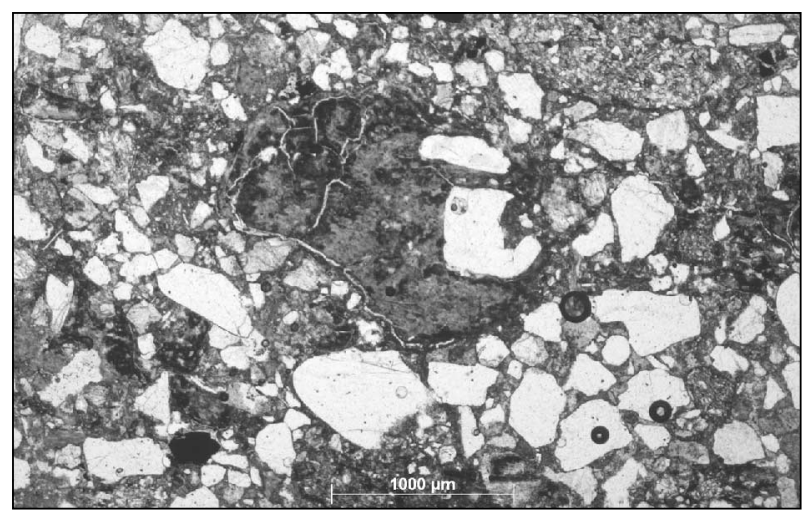

g

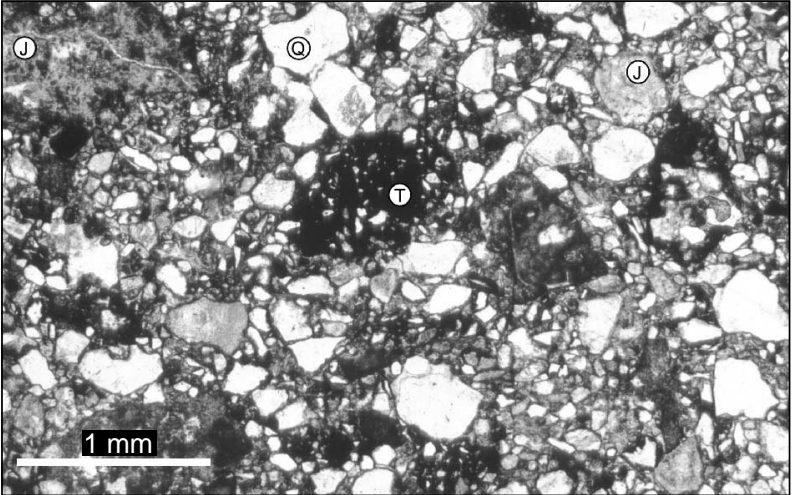

h

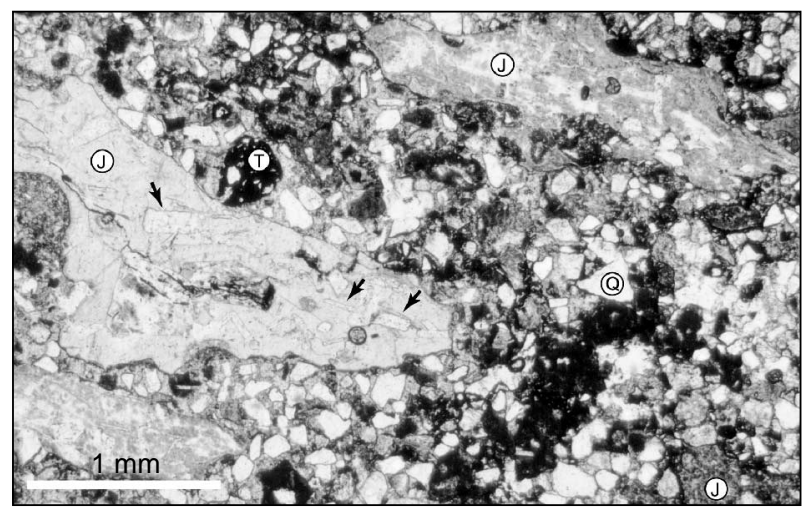

Ross et al., Fig. 4 


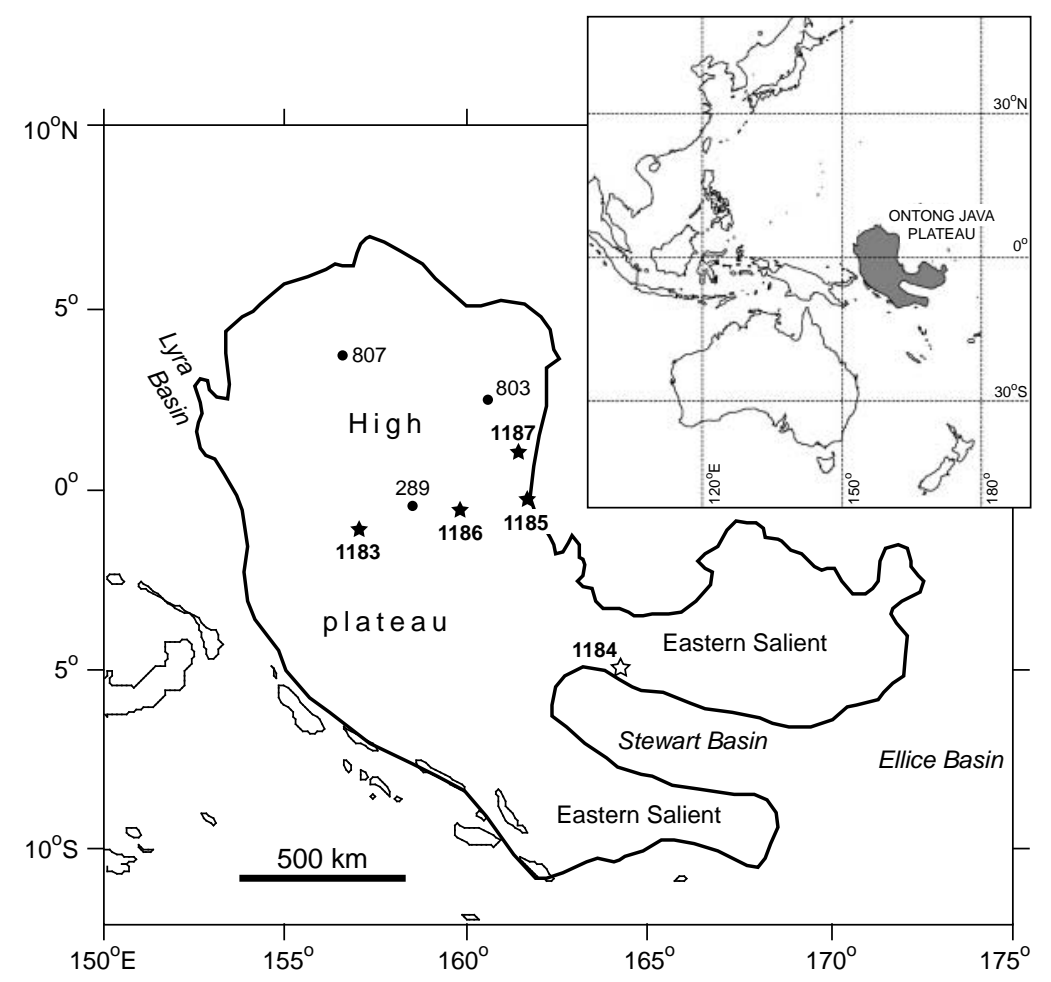

Ross et al., Fig. 5 
a

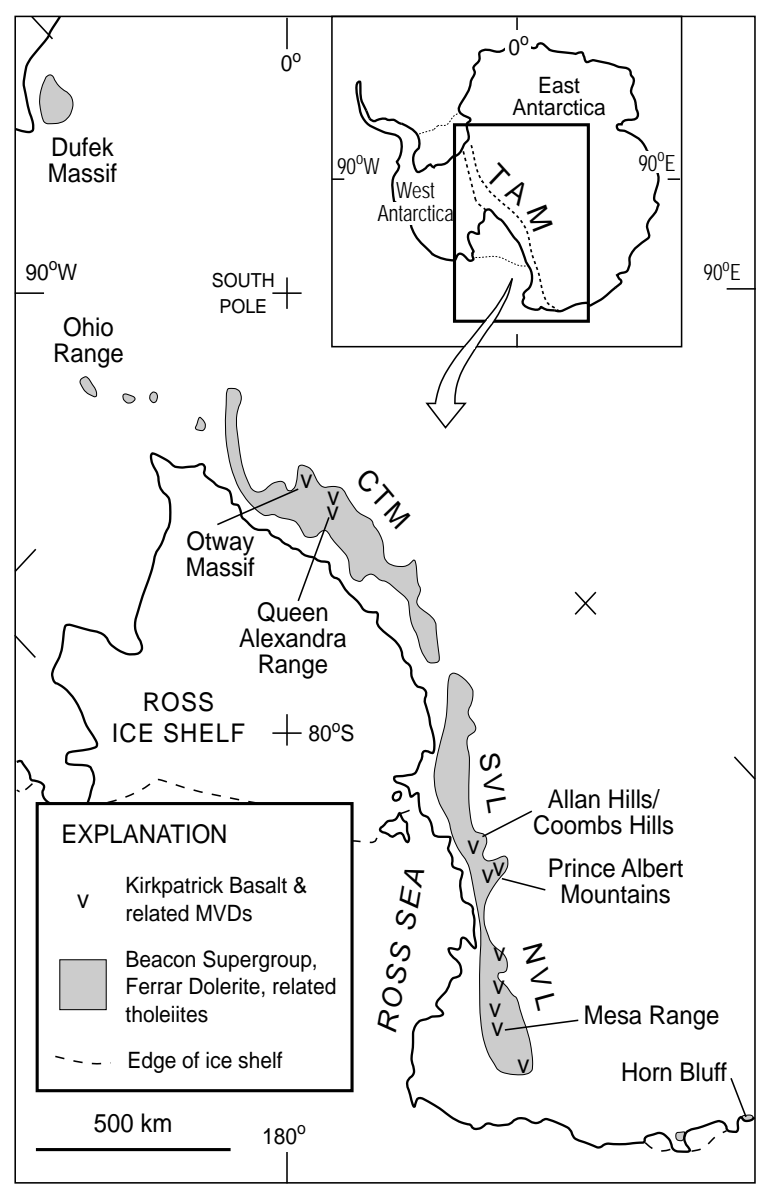

b

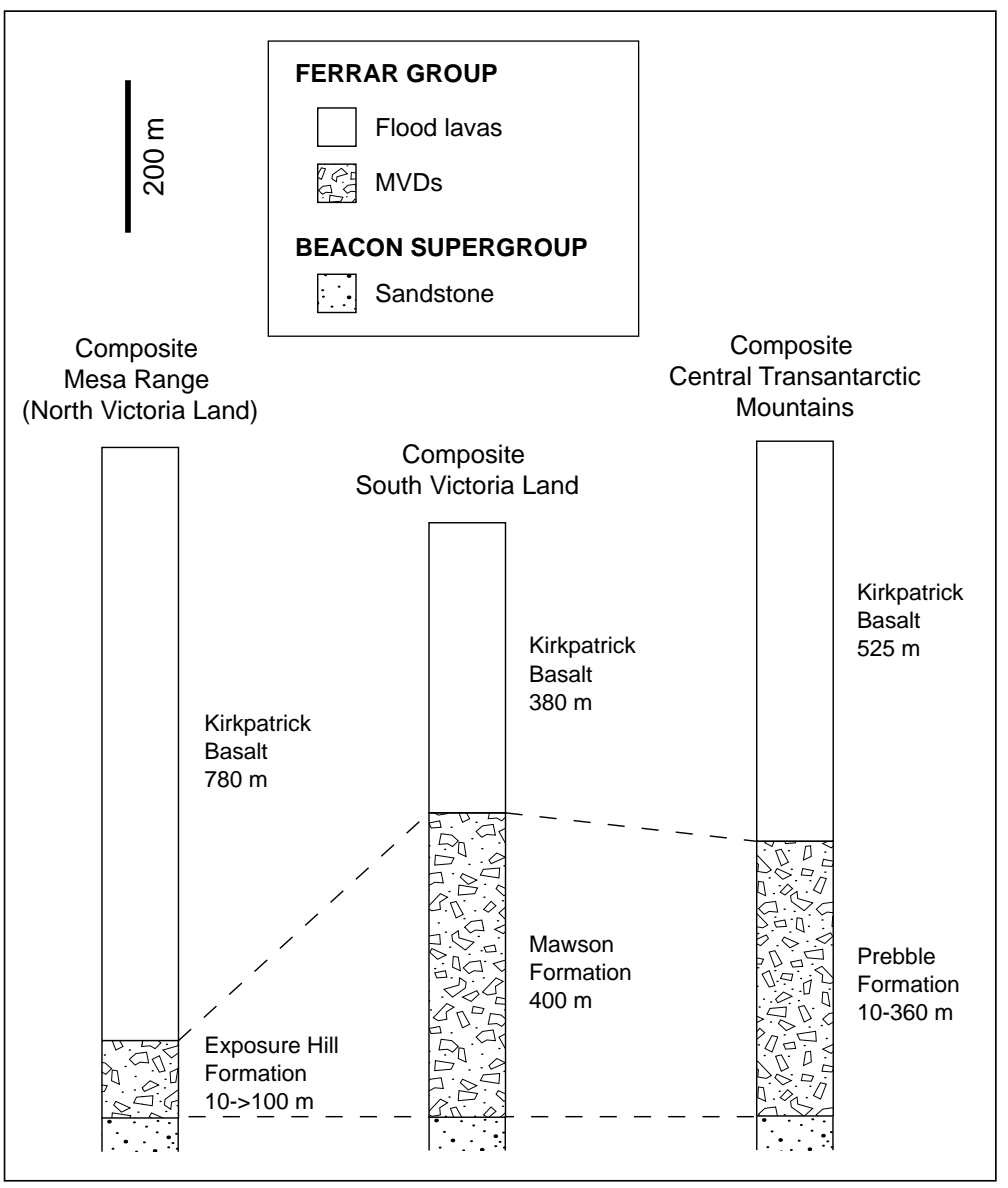

Ross et al., Fig. 6 


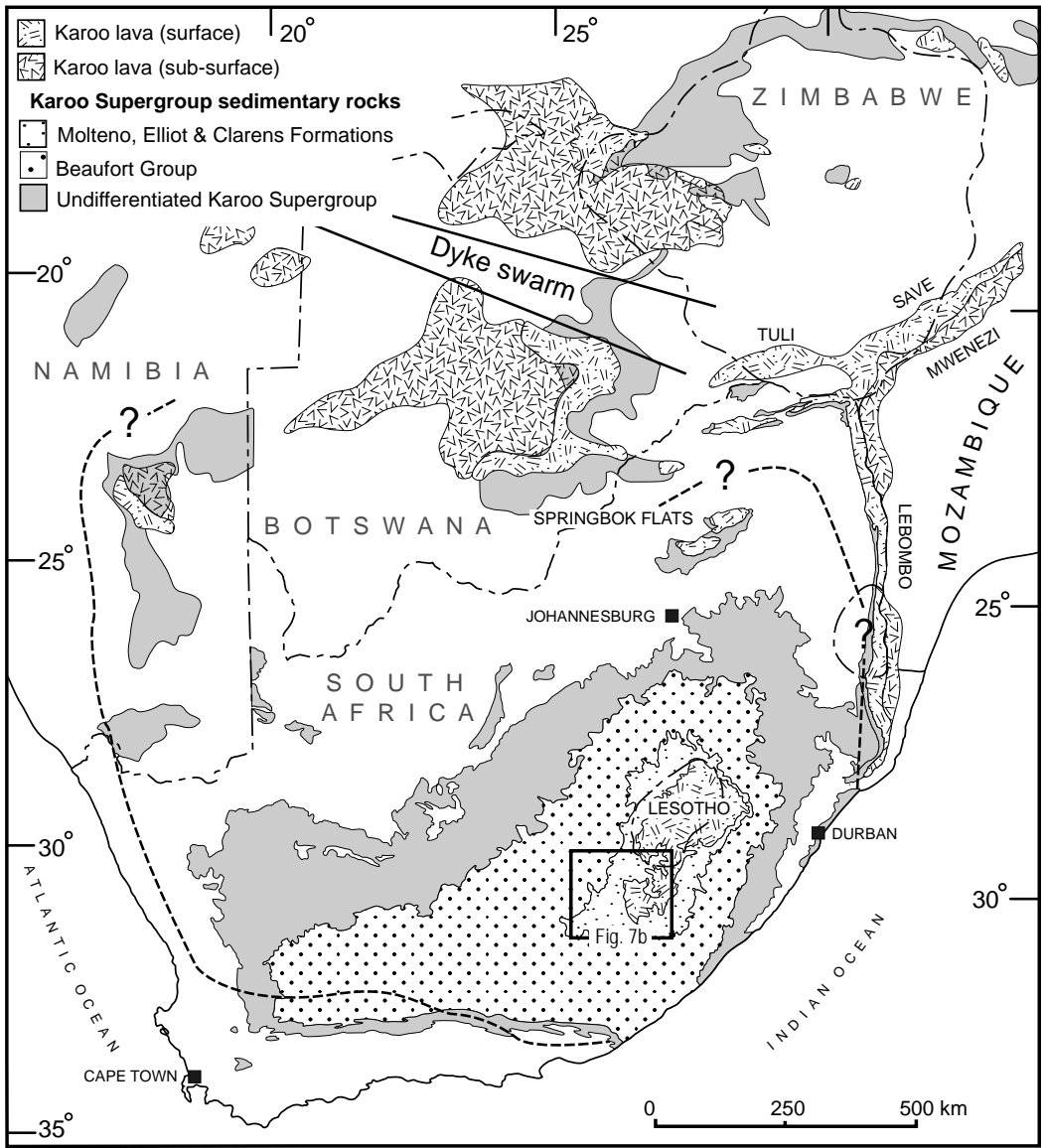

b

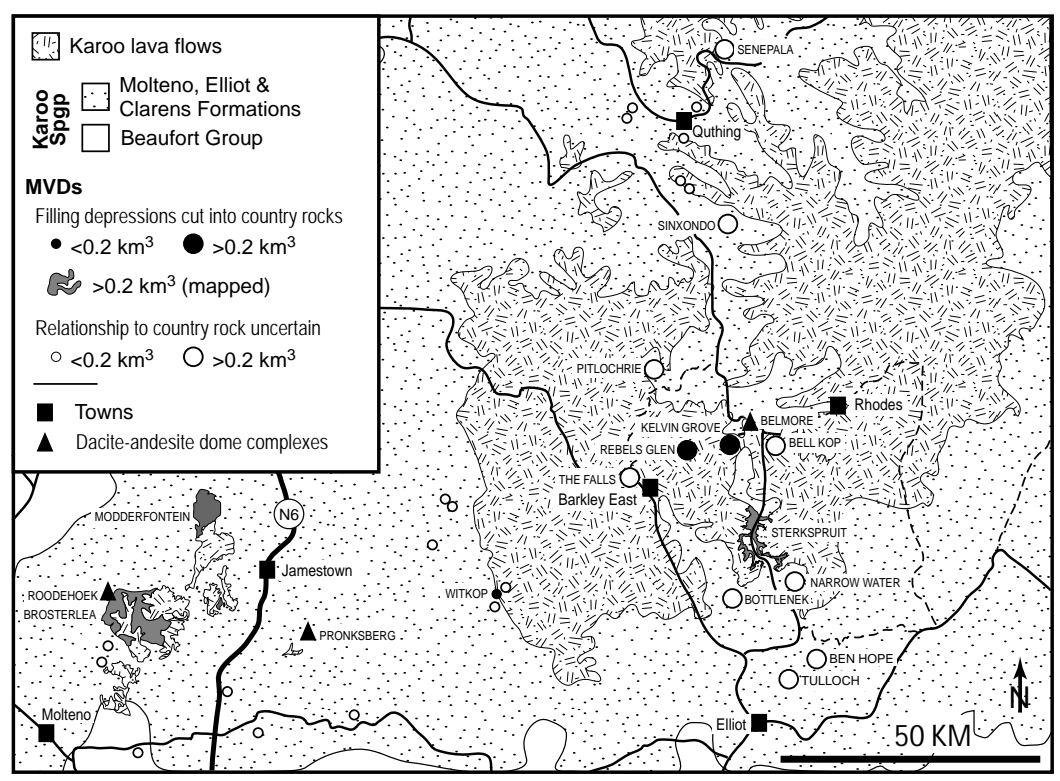

C

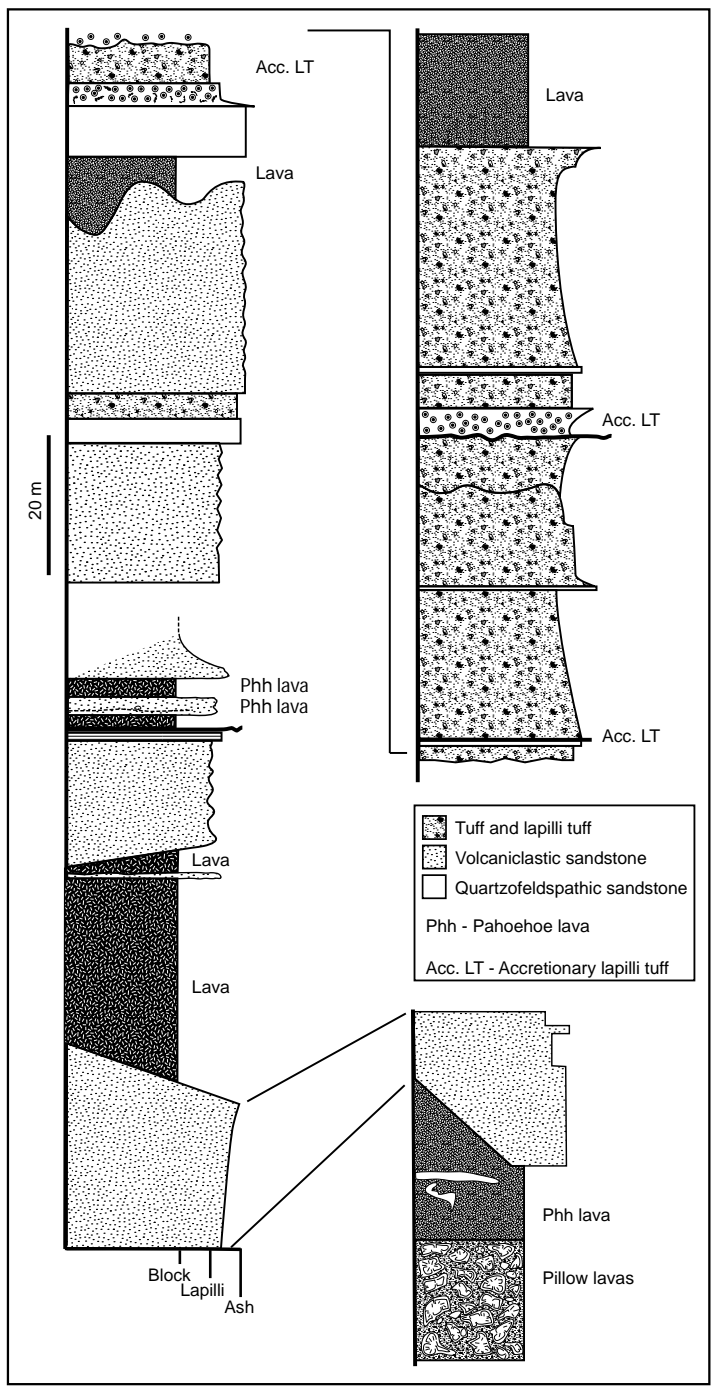

Ross et al., Fig. 7 
a

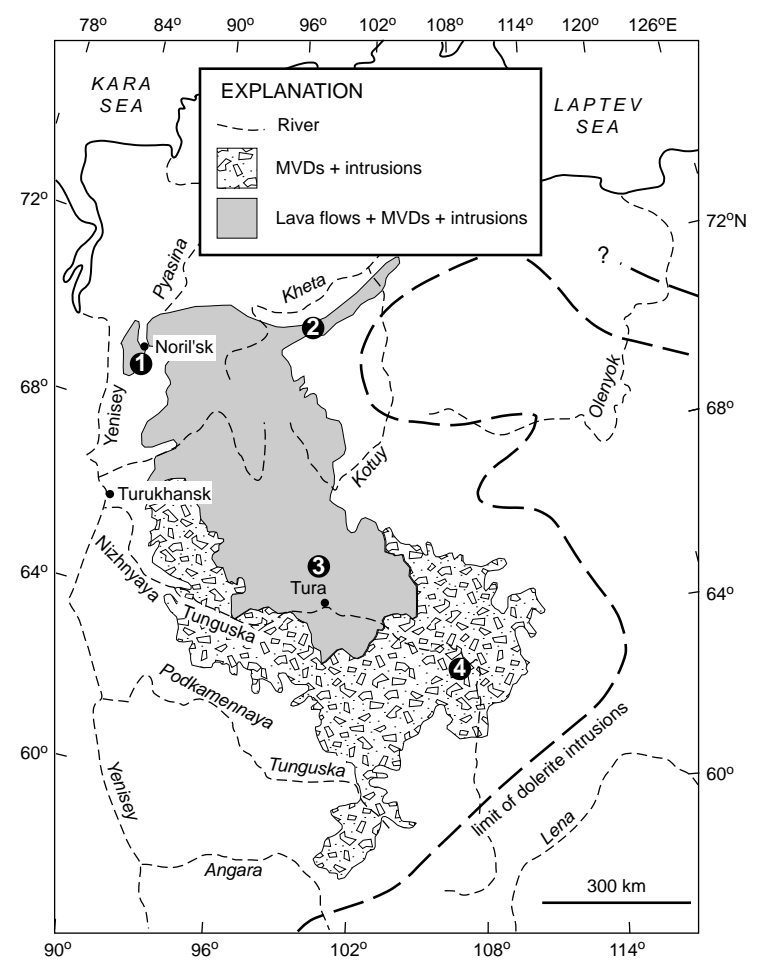

b

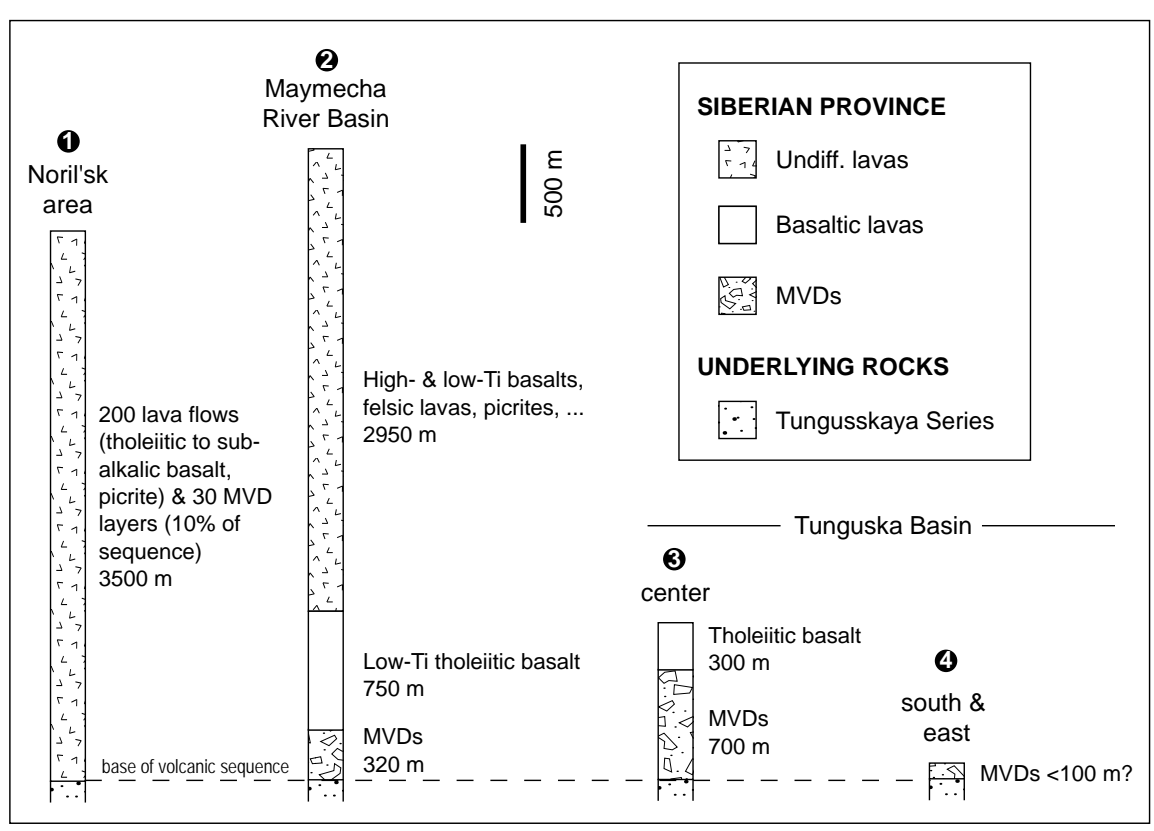

Ross et al., Fig. 8 


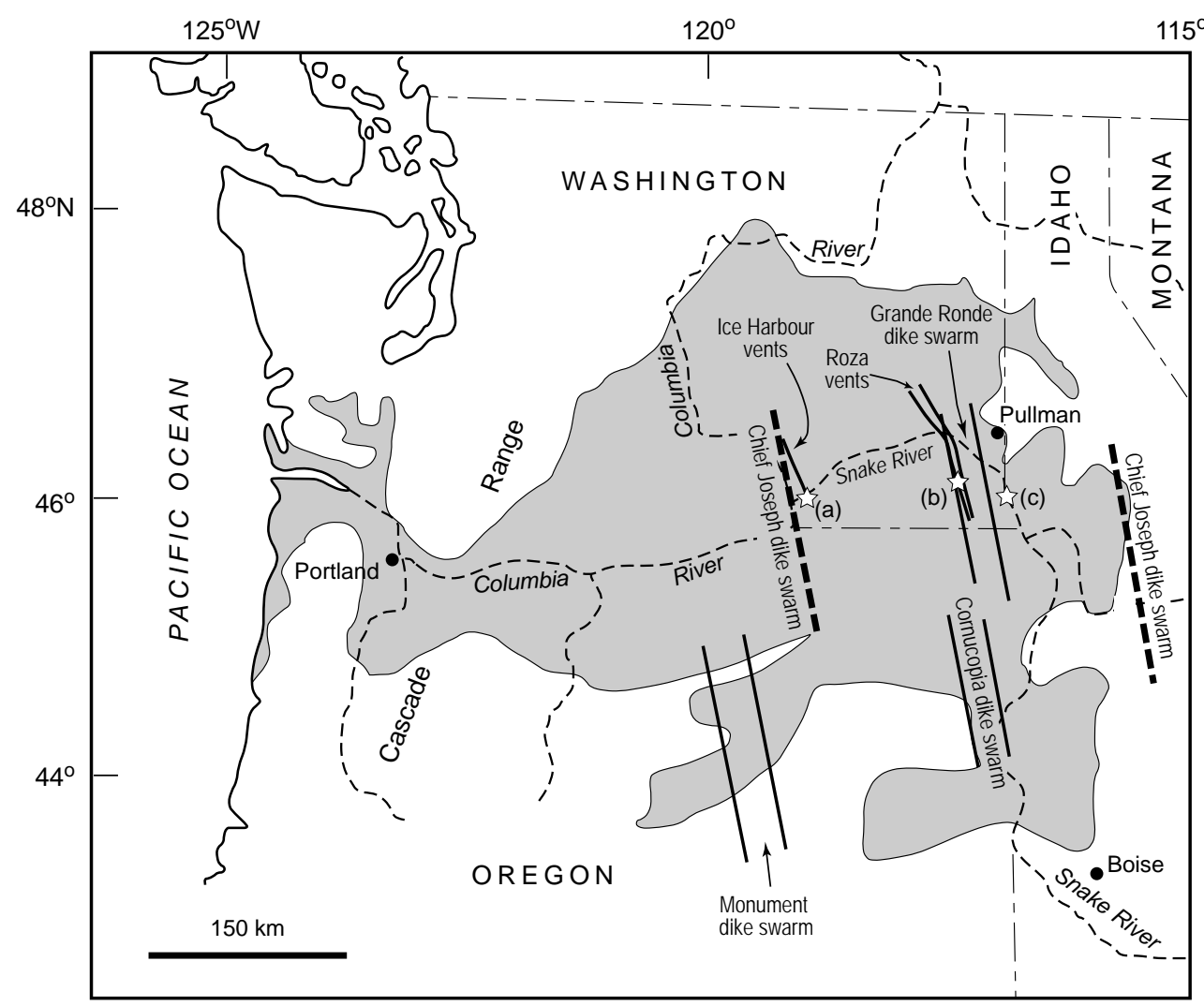

Ross et al., Fig. 9 

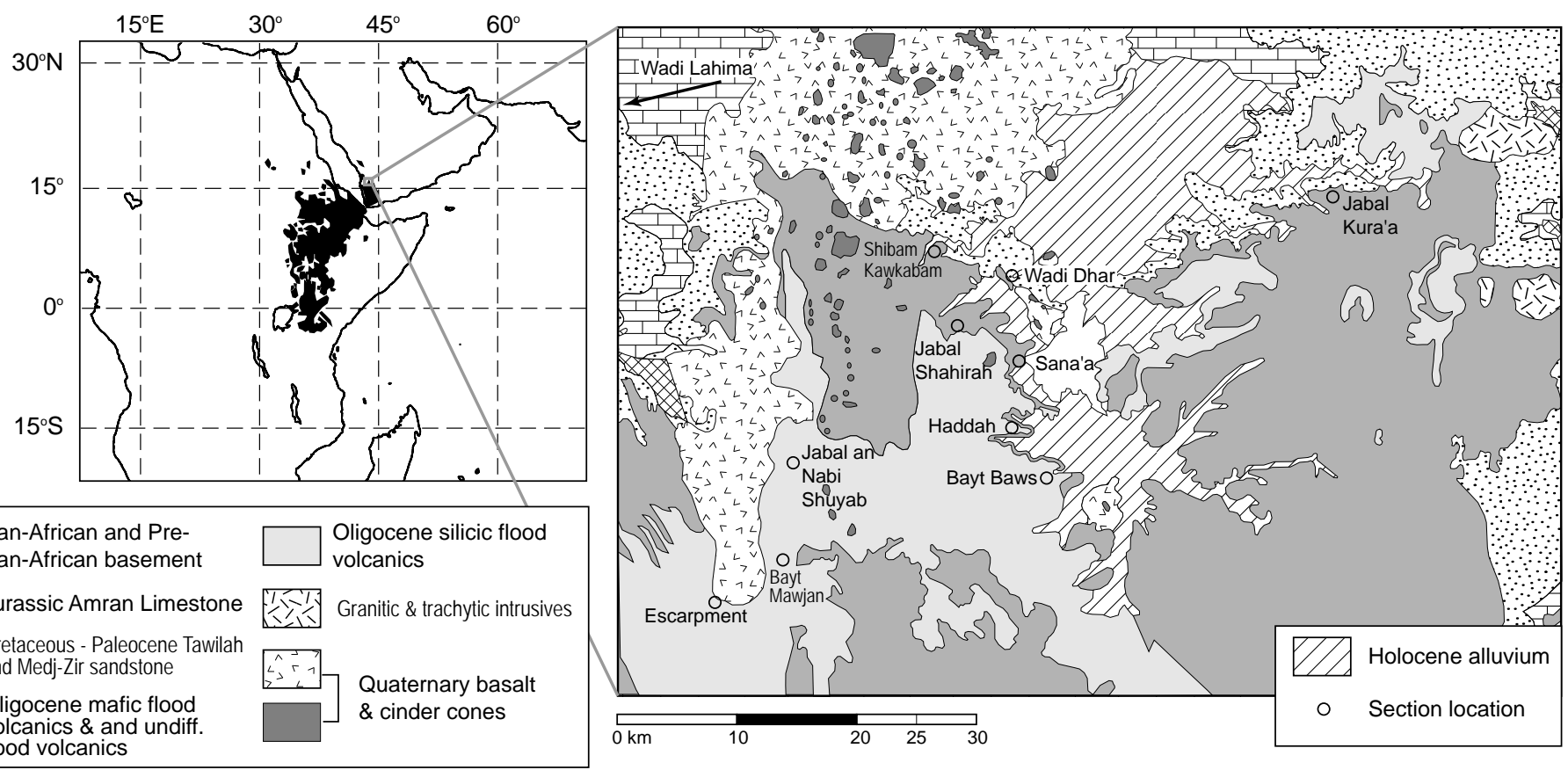

Ross et al., Fig. 10 
West

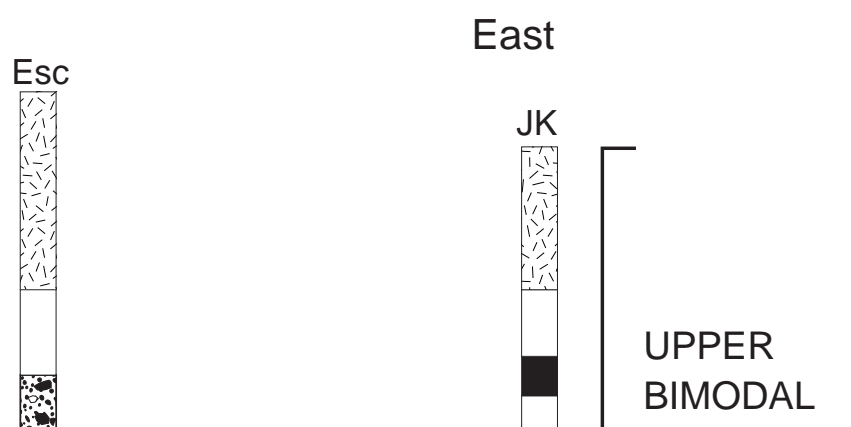

Basaltic lava

$\mathbb{W}$ Trachyandesite lava

B. MVDs

烈罗 Ignimbrite

Silicic tuff

E= Silicic lava

$\underline{4 \mathrm{~km}} \quad 20 \mathrm{~m}$

mafic mega-breccia

BIMODAL
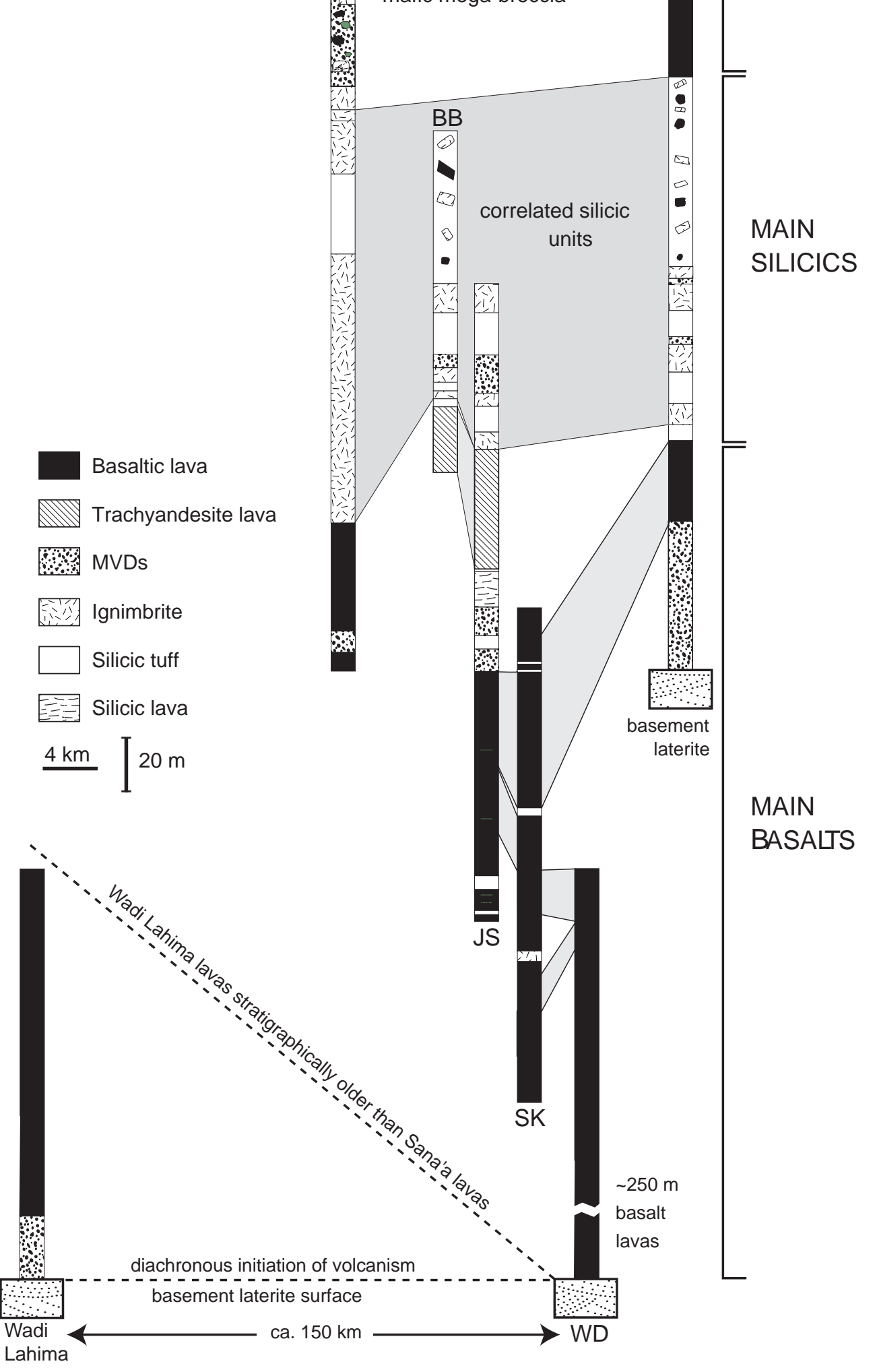

Ross et al., Fig. 11 


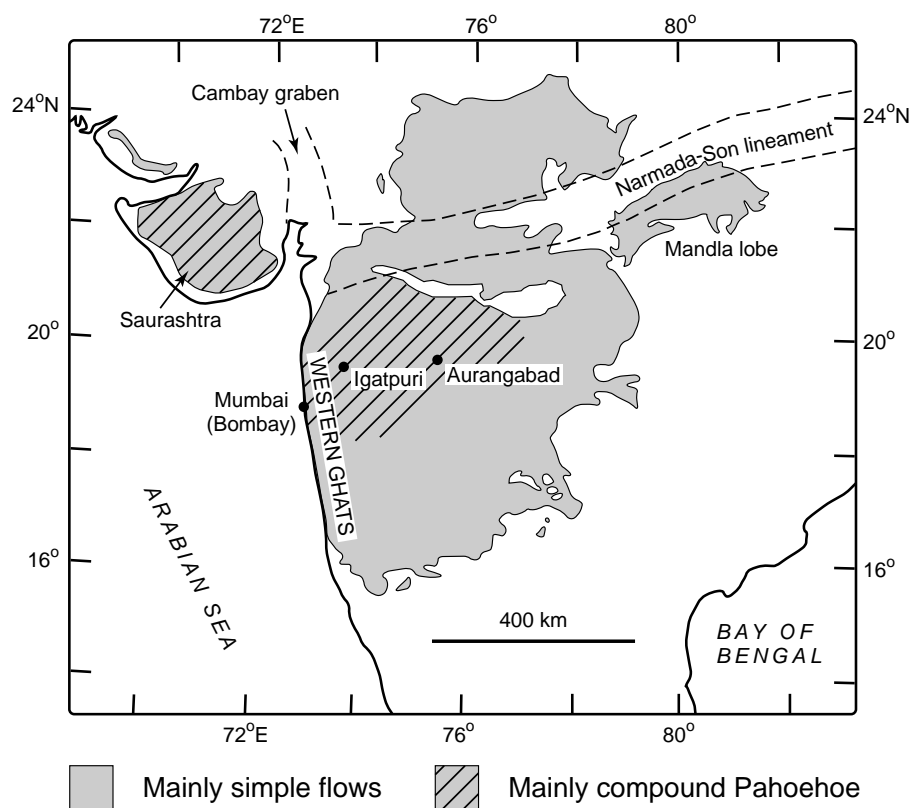

Ross et al., Fig. 12 
a

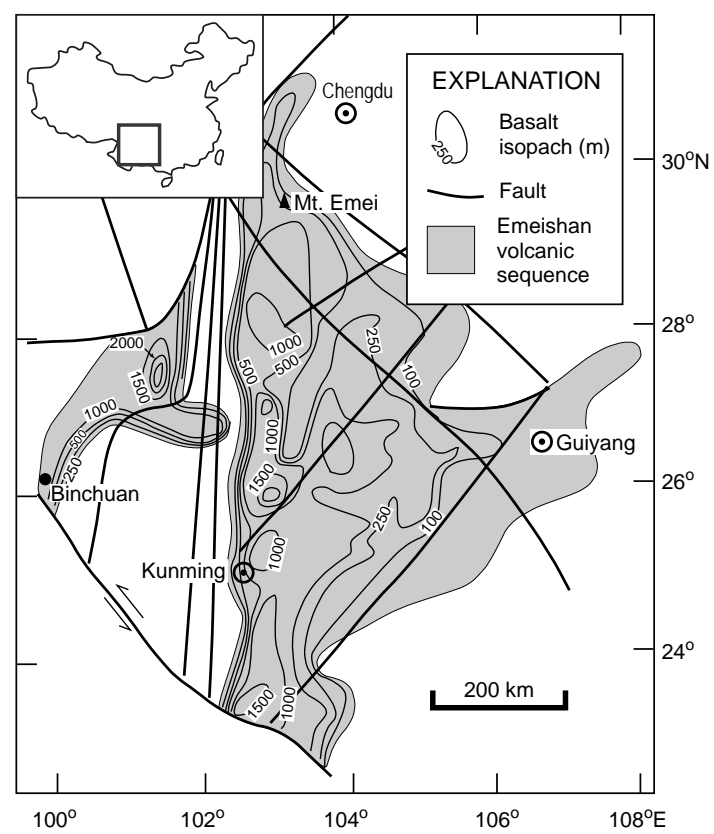

b

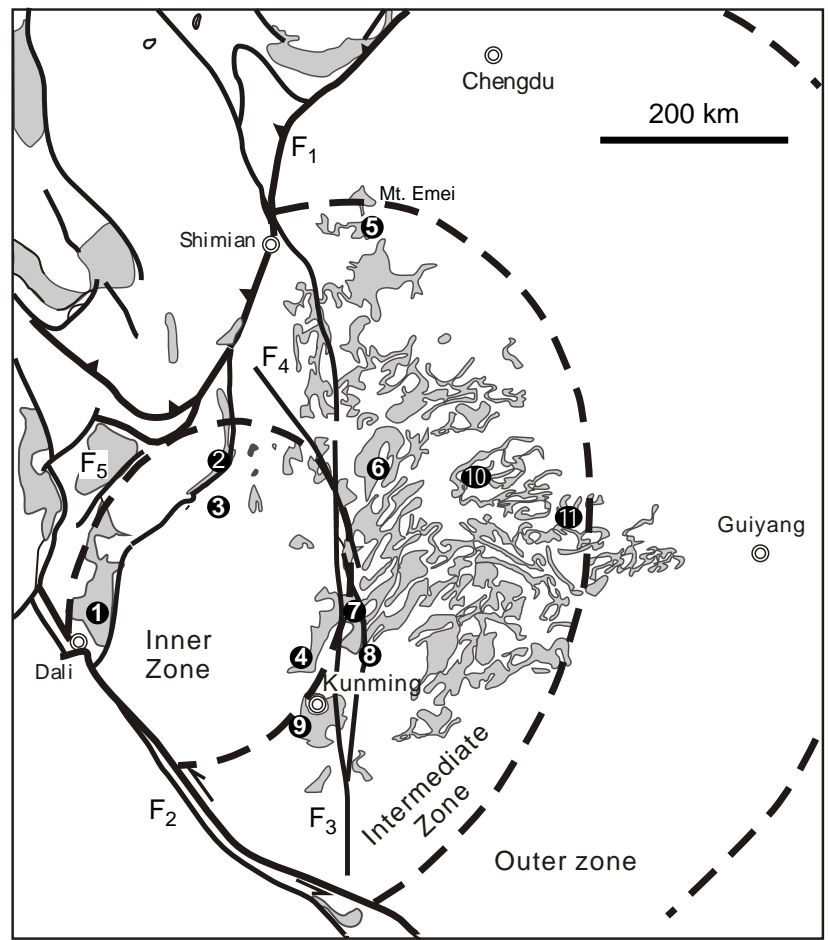

C

d

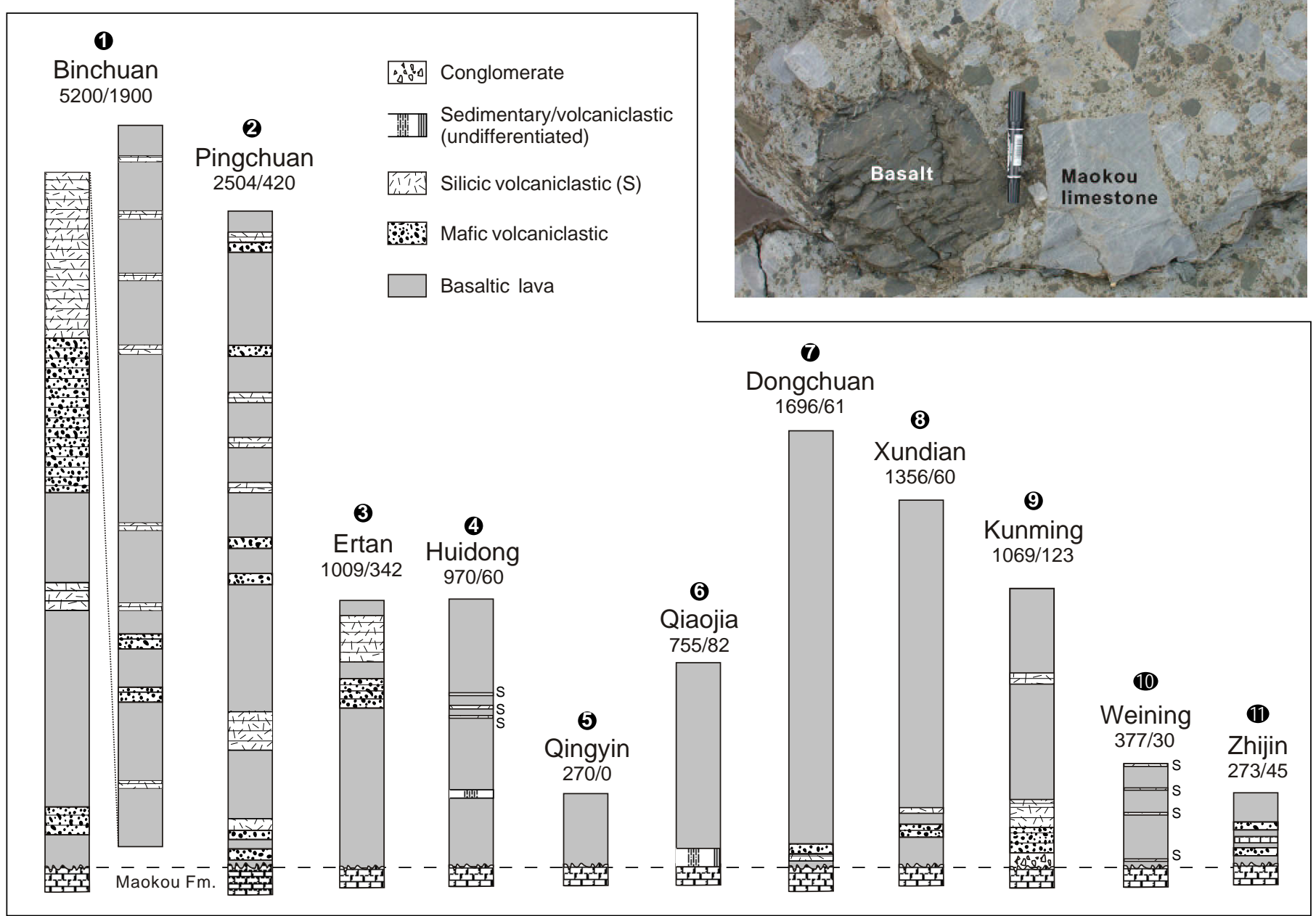

Ross et al., Fig. 13 


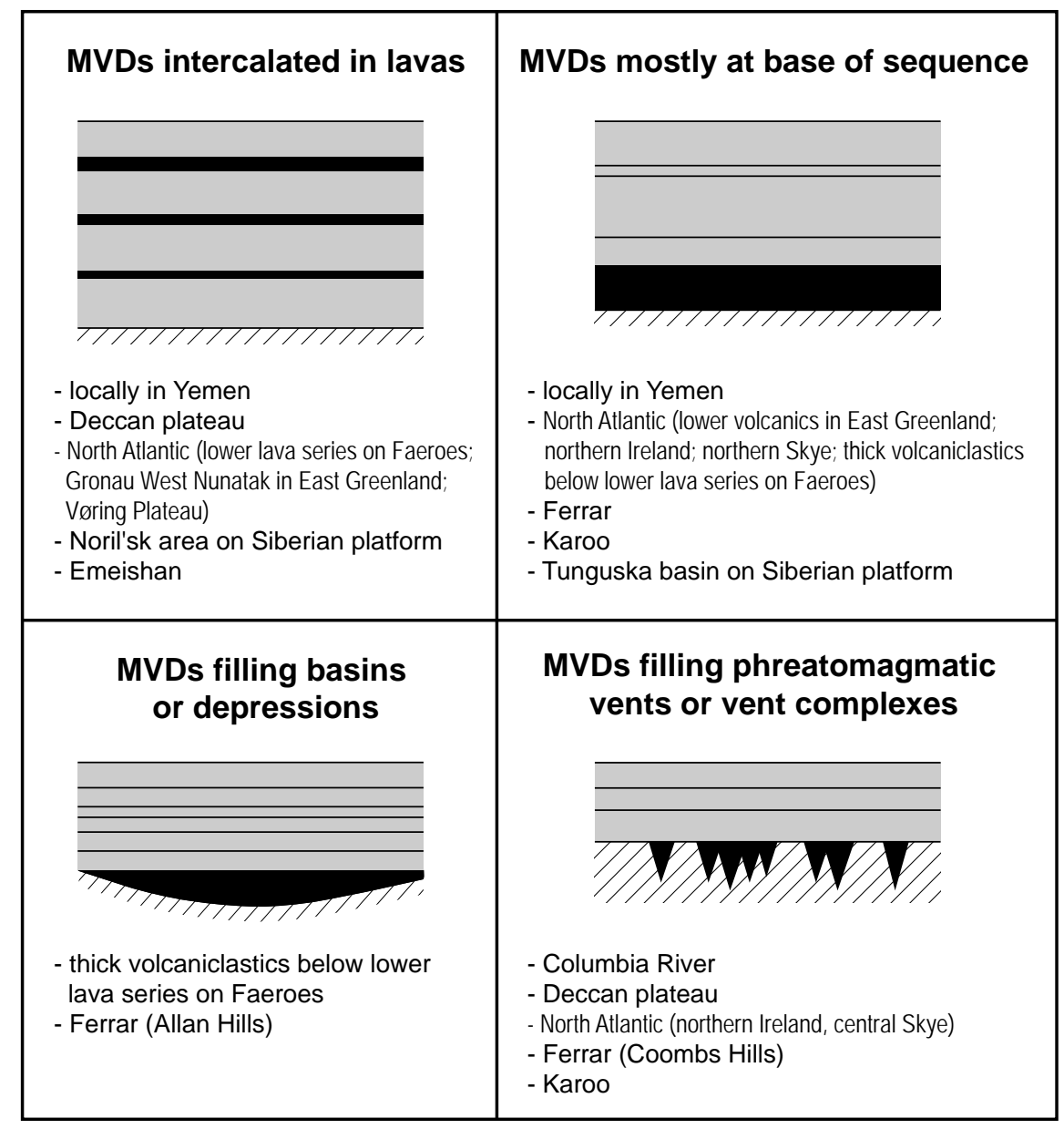

Ross et al., Fig. 14 